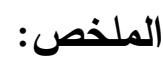

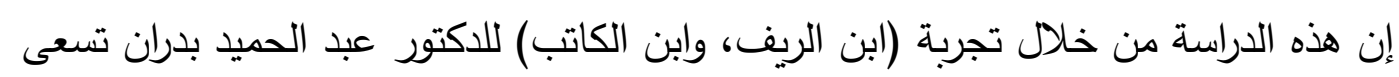

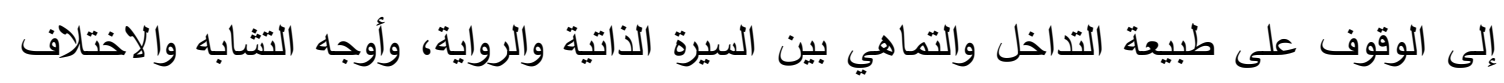
بينهما؛ إذ التنوع في التعبير والتداخل في أدواته، يعد صورة لطبيعة الحياة، التي تقوم على التباين

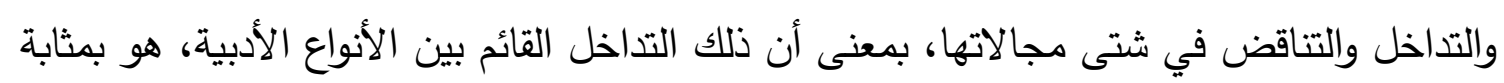

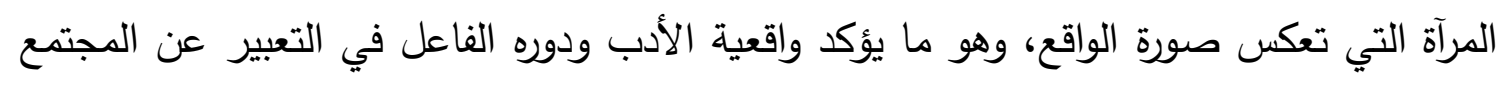

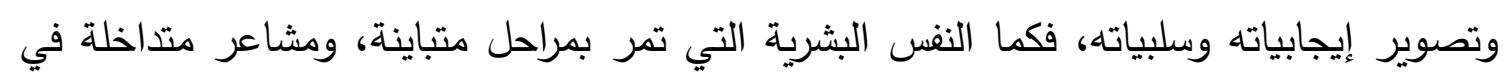

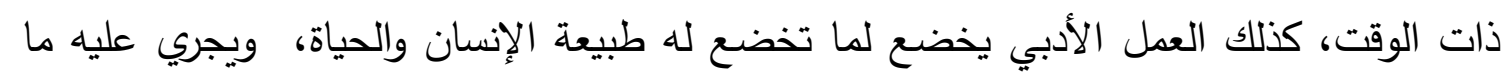
يجري عليهما من التداخل، والتفاعل، والتتلاقي. وفي سبيل إجلاء هذا المفهوم، ولفت انتباه الدارسين إلى هذا المعين السردي الثزّ فقد استعرضت الدراسة معنى التداخل، وموقف بعض النقاد منه، ثم الحديث عن ميثاق السيرة الذاتية،

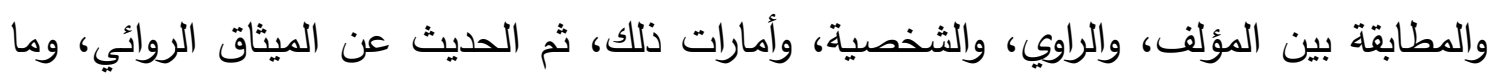

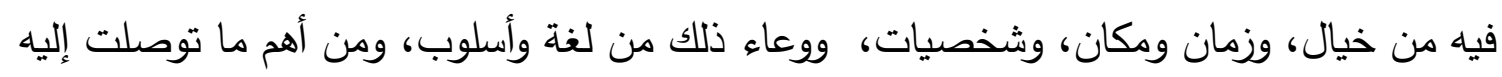

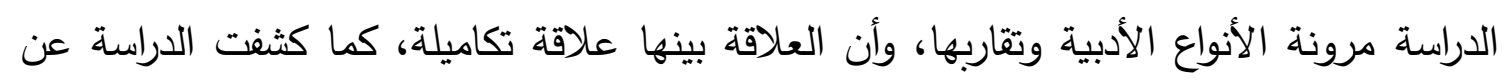

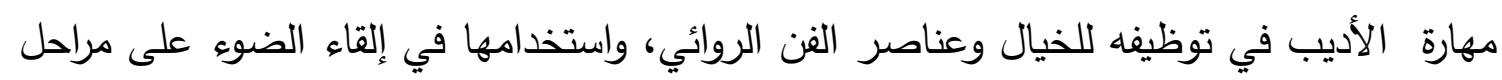
مهمة في حياته، في بيان ماتع ولغة راقية وجذابة.

الكلمات المفتاحية: تداخل- النوع - الأدبي - ابن الريف- ابن الكاتب- بدران - ميثاق السيرة الذاتية - ميثاق الرواية. 


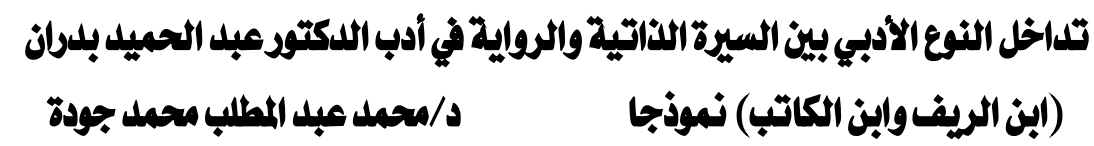

\section{The Summary:}

This study, through the experience of (son of the countryside and the son of the writer) by Dr. Abdel Hamid Badran, seeks to identify the nature of the interacting and identification between the autobiography and the novel, and the similarities and differences between them. Diversity in expression and overlap in its tools, is a picture of the nature of life, which is based on contrast, interacting and contradiction in its various fields, meaning that the existing interacting between literary genres is like a mirror that reflects the image of the reality, which confirms the realism of literature and its effective role in expressing Society and its portrayal of its positives and negatives, just as the human soul is going through different stages and feelings that are interacted at the same time, so literary work is subject to what human nature and life are subject to, and what is happening to them of interaction, and convergence, and in order to explain this concept, drawing attention The study reviewed the meaning of the interaction and the position of some critics about it, then talked about the biographical character, the correspondence between the author, the narrator, and the personality, and the signs of that, then talking about the narrative character, and what it contains of imagination, time and place, and personalities, and a container of language and style, and one of the most important findings of the study is the flexibility and convergence of literary genres, and that the relationship between them is a complementary one. The study also revealed the writer's skill in employing imagination and the elements of fictional art, and using them to shed light on important stages in his life, in a bright statement and elegant and attractive language.

Keywords: interference - genre - literary - son of the countryside - son of the writer - Badran - the character of biography - the chacarter of the novel. 
مقدمة

الحمد لله رب العالمين والصلاة والسلام على رسول الله وعلى آله وصحبه ومن والاه.. وبعد.. إن التتوع في التعبير والتداخل في أدواته، يعد صورة لطبيعة الحياة، التي تقوم على التباين والتداخل والتتاقض في شتى مجالاتها، بمعنى أن ذلك التداخل القائم بين الأنواع

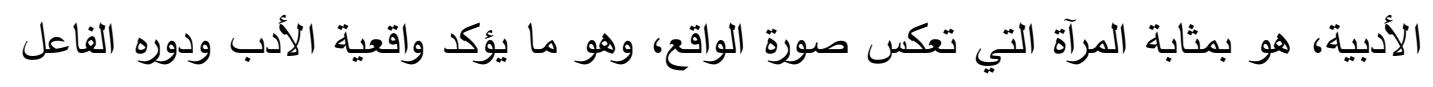

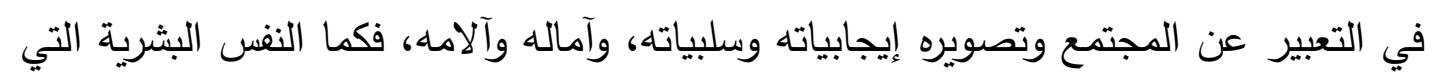

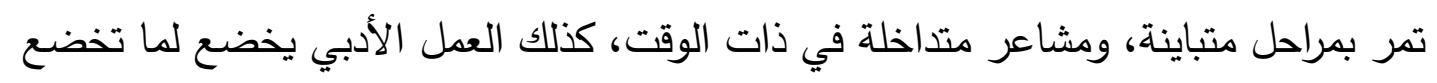

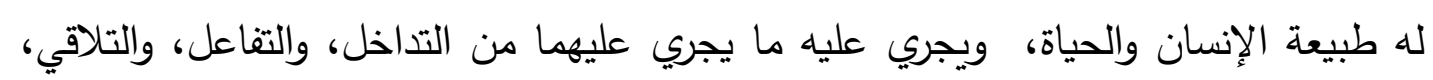

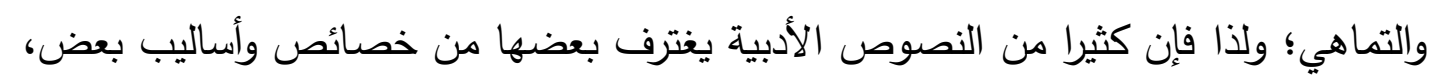

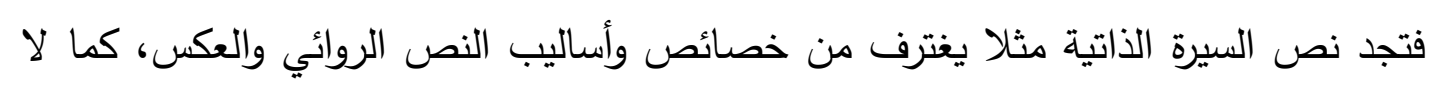

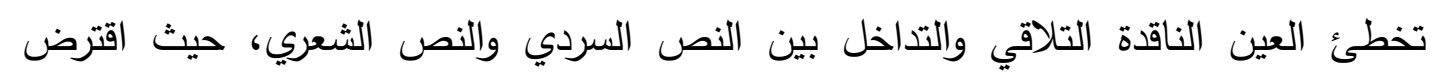

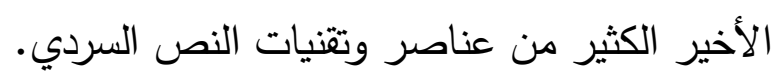

ومن هؤلاء الأدباء الذين غاصوا في واقعهم الشخصي، وصوروه بطريقة أدبية فنية راقية، الأنا،

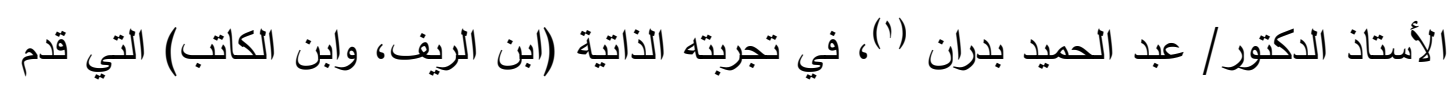

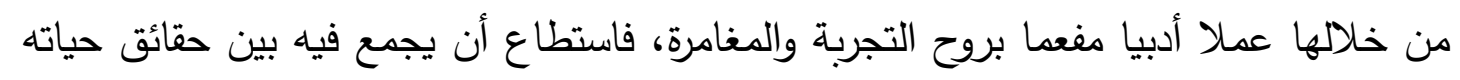

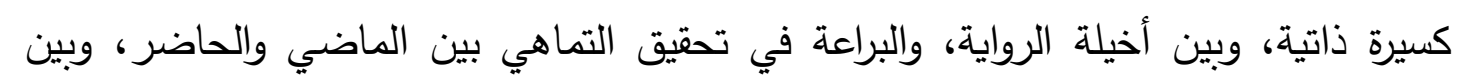
الواقع الثخصي والواقع الجماعي، بين الواقع والمتخيل، أو الحقيقة والخيال.

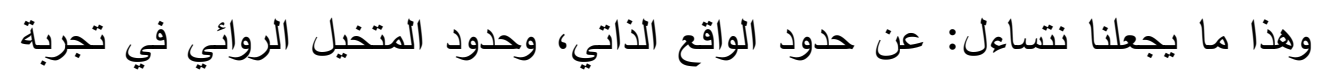

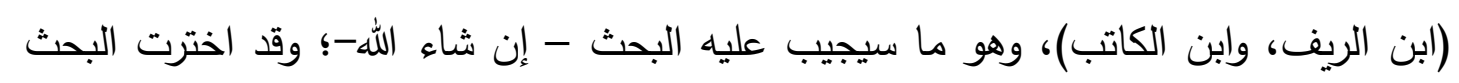

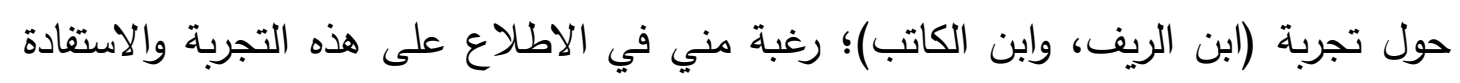

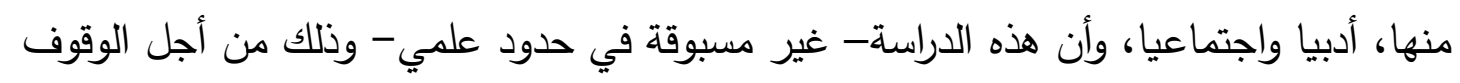

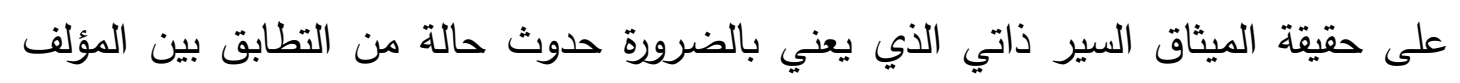

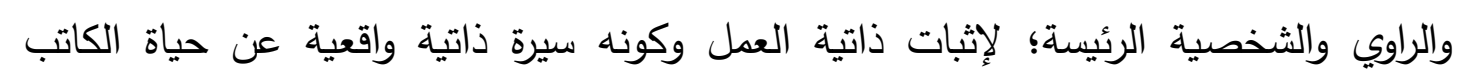

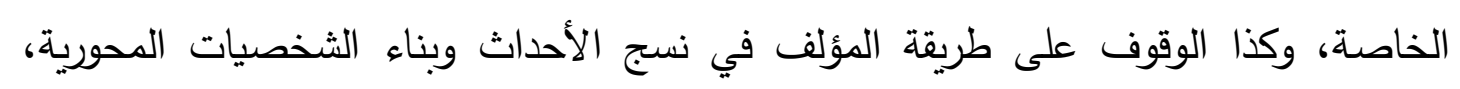

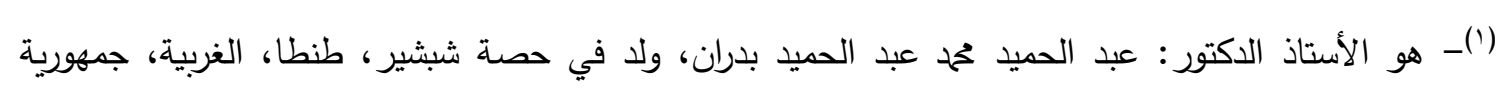

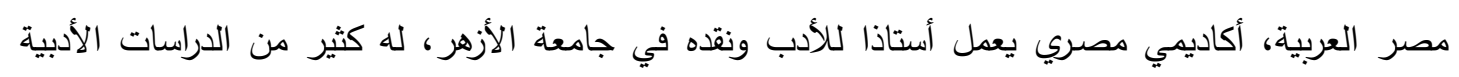
والنقدية المنشورة في عديد من المجلات المصرية والعربية، وله عدد من الأعمال الإبداعية شعرا ونثرا. 


\section{تلداخل النوع الأببي بين السيرة الثاتية والرواية في أدب الدكتور عبد الحميد بلدان \\ دمحمل عبد المطلب محعل جودة \\ (ابن الريفوابن الكاتب) نموذجا}

ودور الزمان والمكان، وإبراز أبعادها المختلفة، وغير ذلك من التقنيات الروائية التي وظفها

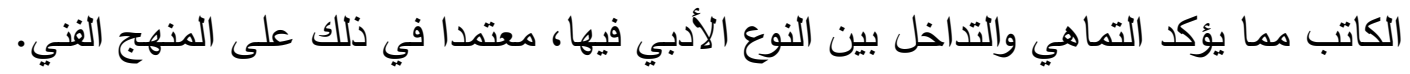

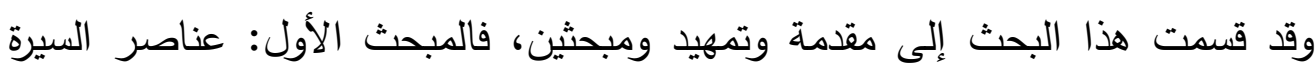

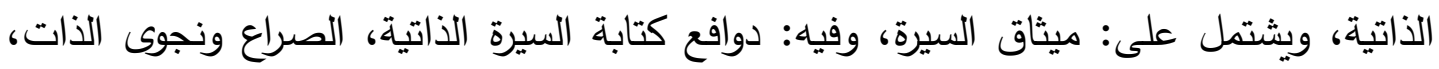
الصدق والصراحة.

المبحث الثاني: الميثاق الروائي ويشتمل على: الحقيقة والخيال، الثخصية، الزمان، المكان، لغة روائية.

وأسأل الله العون والقبول وصلى الله وسلم وبارك على نبينا محمد وصحبه وآله وسلم، وآخر دعوانا أن الحمد لله رب العالمين. 
(في معنى التداخل)

إن الحديث عن تداخل النوع في تجربة (ابن الريف، وابن الكاتب) يقودنا إلى إلقاء الضوء

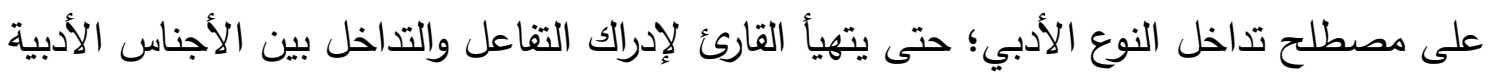

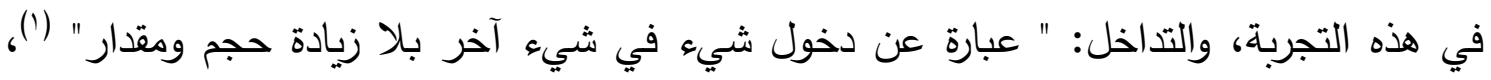

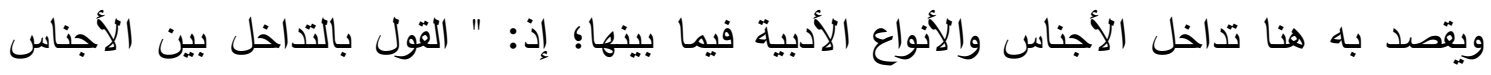

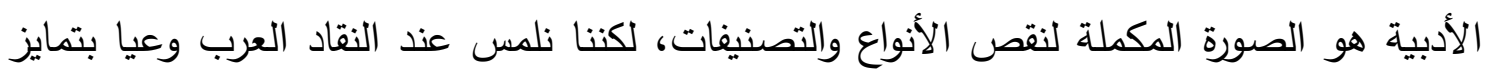
الأنواع والأجناس.. على أن القناعة الراسخة تظل في نظرنا متمسكة بميوعة الحدود بين الأجناس

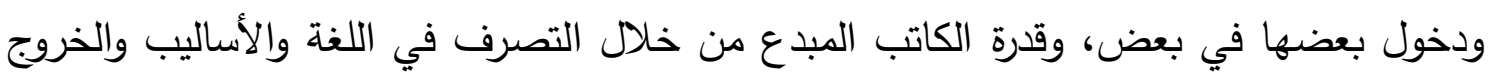

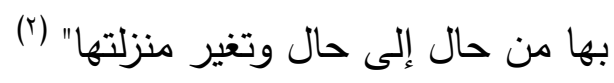
والمراد " بتمازج الأجناس أو امتزاجها هو صدور التيال الأجناس الأدبية على اختلاف أنواعها

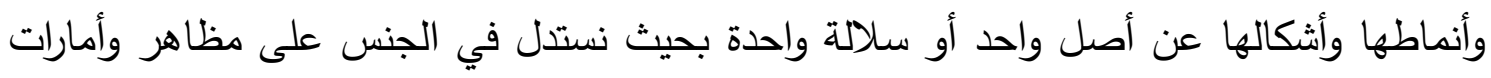

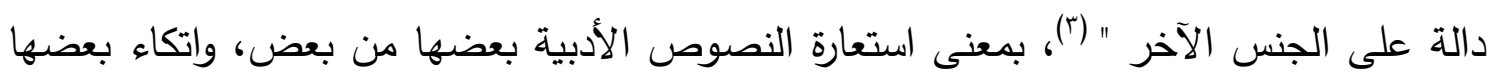

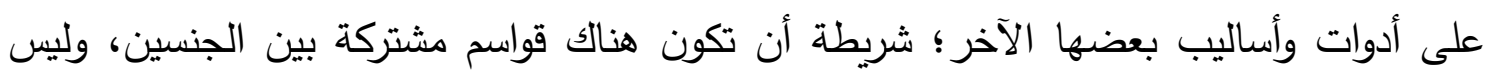

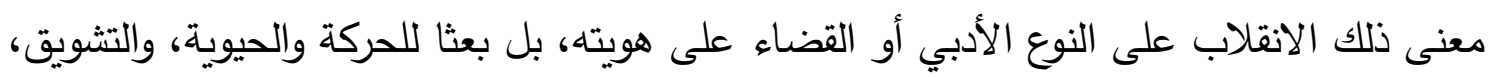

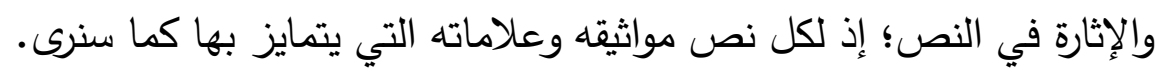

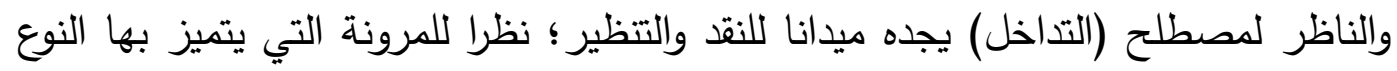

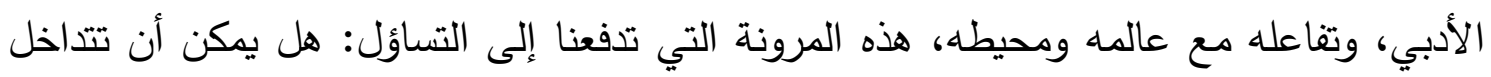

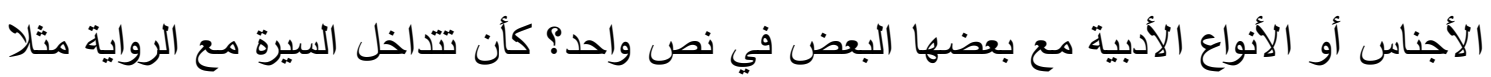

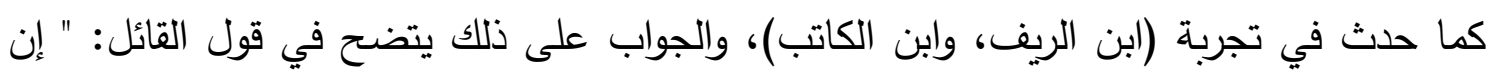

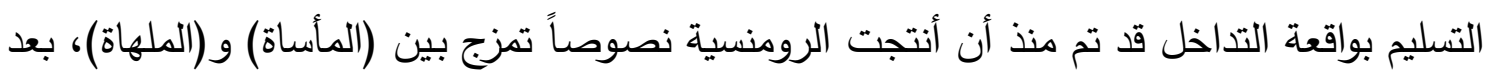
أن كانت نصوص المرحلة الكلاسيكية تحافظ على الحدود القائمة بينهما.. وتأكدت واقعة التداخل

(1) - معجم التعريفات (قاموس المصطلحات وتعريفات علم الفقه واللغة والفلسفة والمنطق والتصوف والنحو

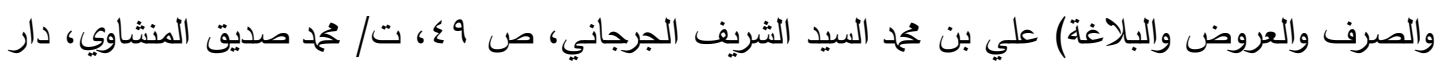
الفضيلة، الإمارات، دبي، د ت ت.

(r) -التفاعل في الأجناس الأدبية (مشروع قراءة لنماذج من الأجناس النثرية القديمة من القرنين الثالث، والسادس

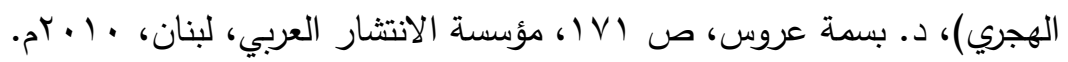

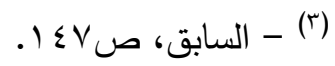




\section{تلداخل النوع الأببي بين السيرة الثاتية والرواية في أدب الدكتور عبد الحميد بلدان

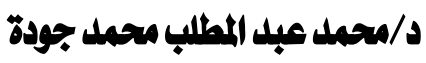

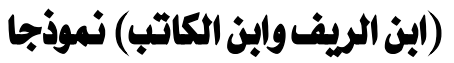

في العصر الحديث على لسان القائلين بأن (الرواية) هي ملتقى الأنواع الأدبية؛ أوهي ثمرة مزج

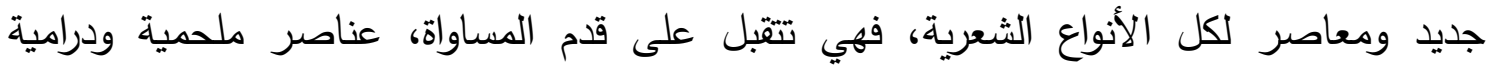

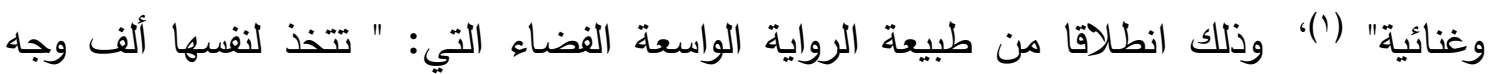

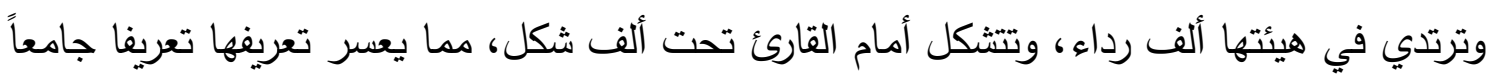

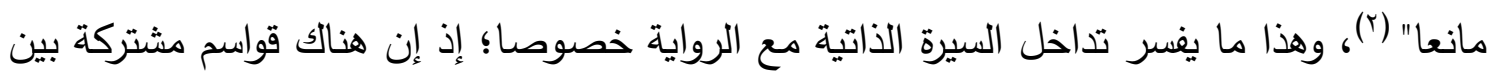

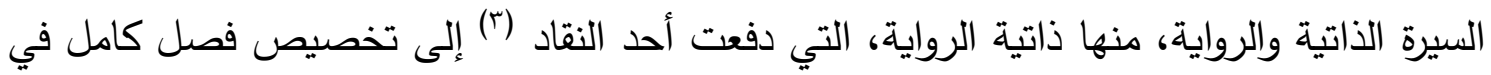
دراسته (تطور الرواية العربية) بعنوان (رواية الترجمة الذاتية)، ك(عودة الروح لتوفيق الحكيم)، و(الأيام لطه حسين) وغيرها، وهي نماذج اعتمد فيها أصحابها على تجاربهم الذاتية. ويرى بعض النقاد كالدكتور محمد صابر عبيد أن ظاهرة التداخل بين الأنواع الأدبية، ظاهرة

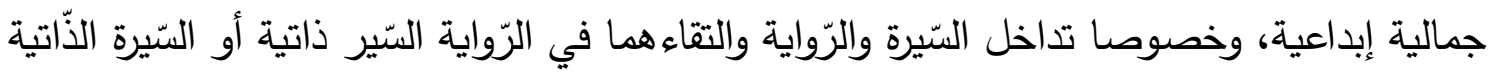

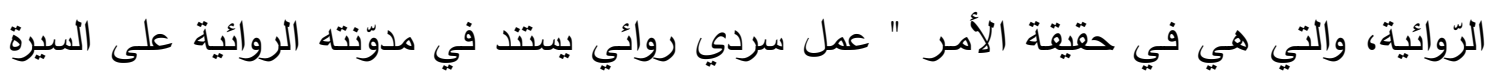

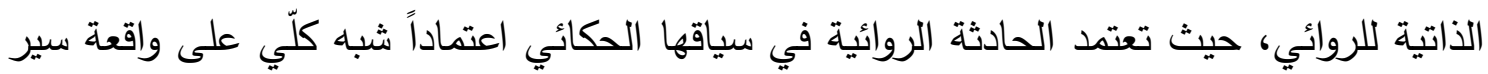

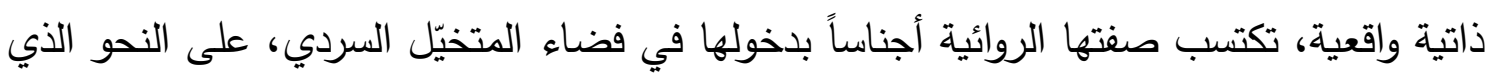

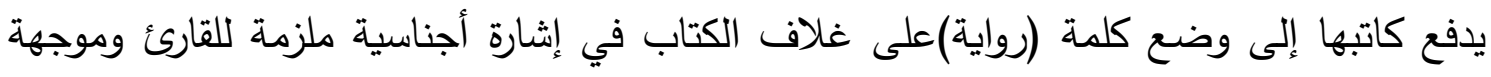

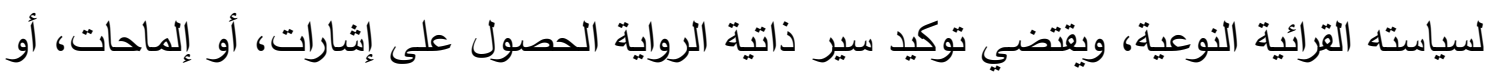

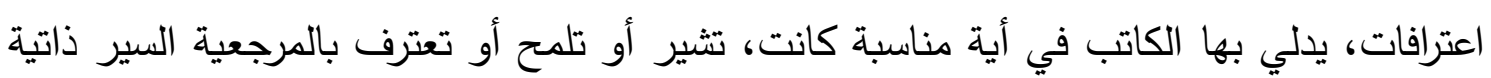

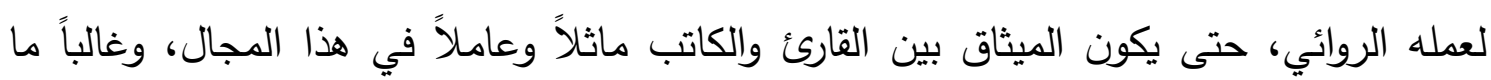

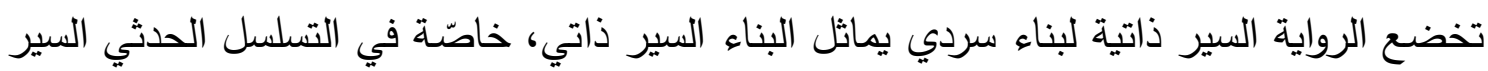
ذاتي وعلاقته بالأزمنة والأمكنة والثخصيات الداعمة لموقف الذات السيرية الساردة، وهي تروي

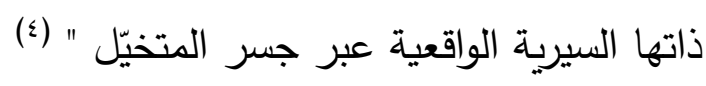

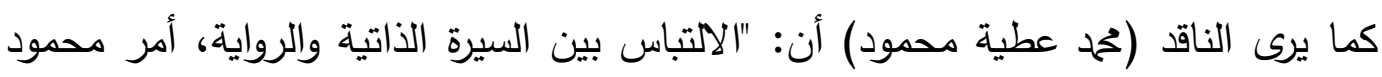

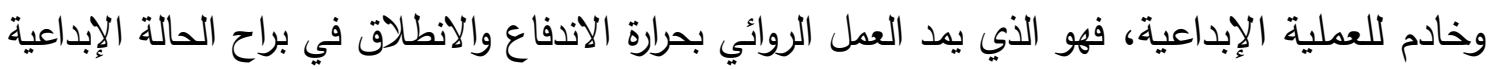

( () - تداخل الأنواع بين القاعدة والخرق (دراسة نظرية)، الدكتور لؤي علي خليل، صـام ا، مجلة جامعة دمشق-

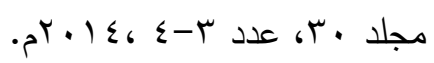

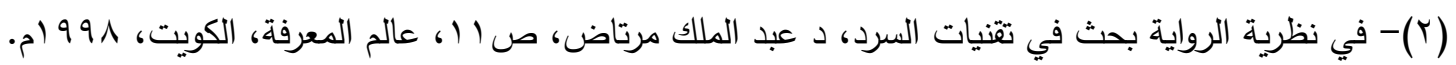

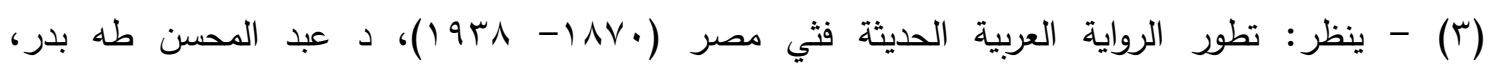

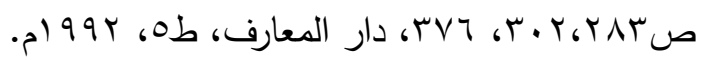

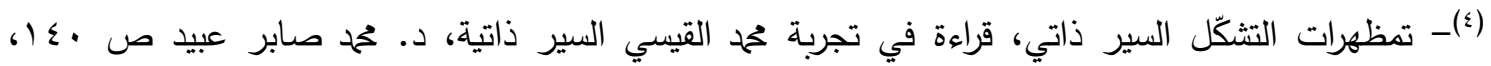

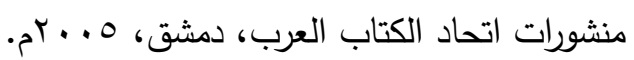


المتسقة مع المضمون والحالة الإنسانية والإبداعية التخييلية والهنسية التي تنطلق من الذات، نحو الآخر /

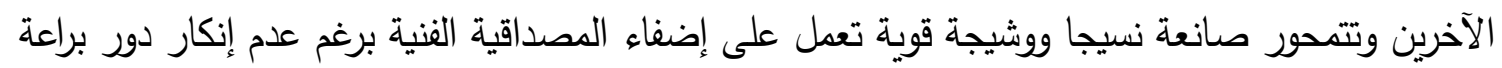

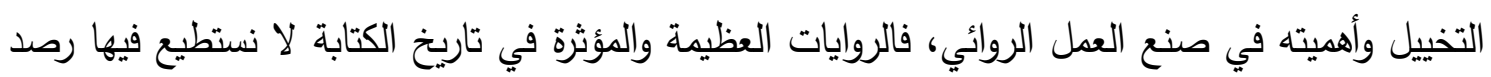

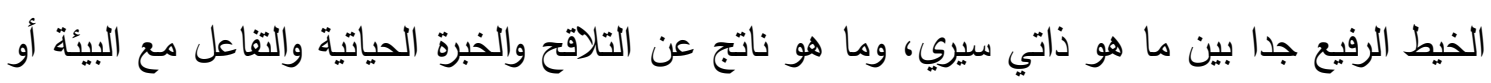

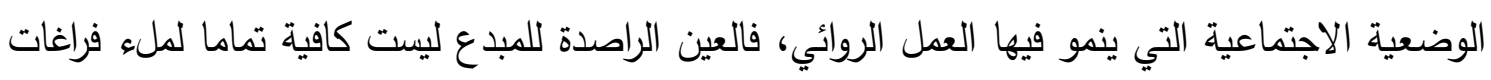

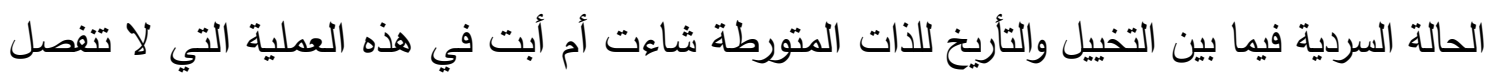

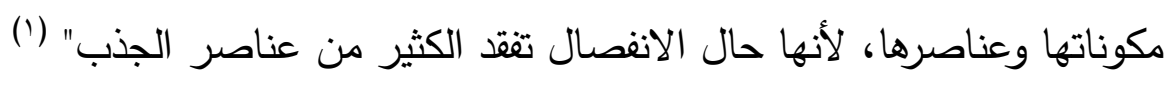
ومن هنا فالأنواع الأدبية لا تعرف الجمود والثبات، بل هي متغيرة؛ تبعا لتغير الحياة وتناقضاتها: "

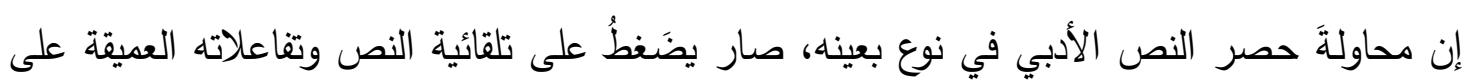

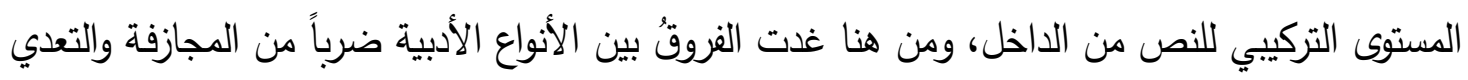

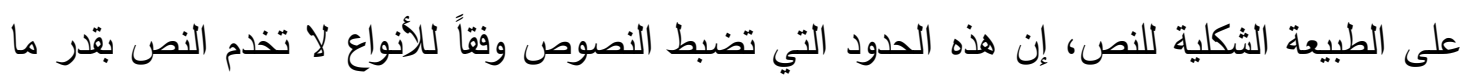

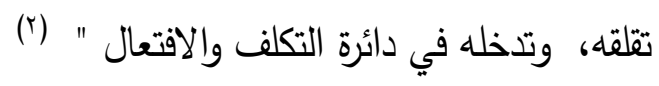
ولقد آمن كثير من المبدعين والأدباء بهذا التداخل، فجاءت نصوصهم حافلة بهذا التماهي والتزاوج بين النصوص الأدبية، ولعل الدكتور / عبد الحميد بدران في تجربته (ابن الريف، وابن الكاتب) واحد من هؤلاء لئه

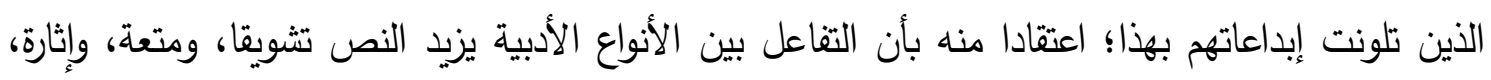
وجمالا، وخاصة السيرة الذاتية التي تعرض في ثوب الرواية وجمالياتها.

(1)-ـ ينظر : مقال: السيرة والرواية، تدخل الخيال لخيانة الواقع، أحمد رجب، بتاريخ 11/0/19 • بم، موقع https:middle-est-online.com

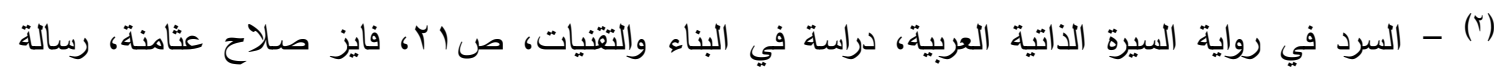

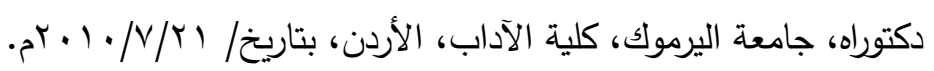




\section{تلاخل النوع الأببي بين السيرة الداتية والرواية في أدب الدكتور عبد الحميد بلدان}

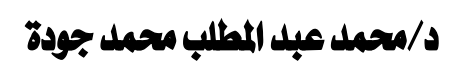

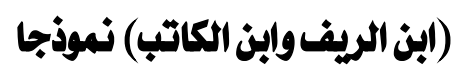

المبحث الأول: عناصر السيرة الذاتية

ميثاق السيرة

تعد السيرة الذاتية المرَّاة، أو المنسوجة في نسيج روائي، نوعا من أنواع الكتابة الأدبية الناتجة عن التماهي بين السيرة الذاتية التي توثث لحياة شخصية من الثخصيات، والرواية التي فئي

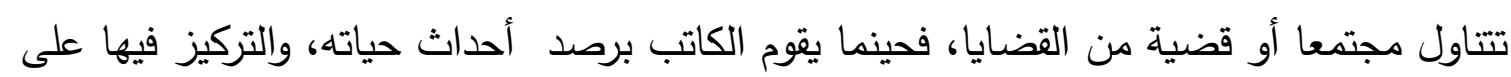

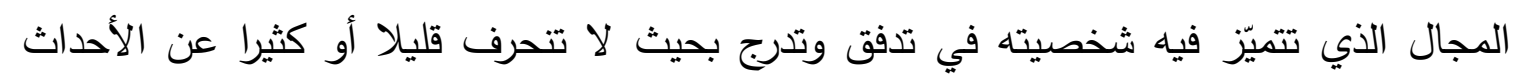

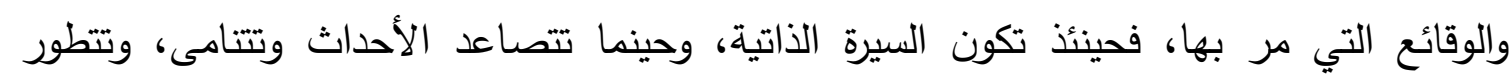
الثخصيات وتتغير، ويتأرجح الزمان بين الماضي والحاضر في انتظام، وعلى رأس ذلك الك الخيال

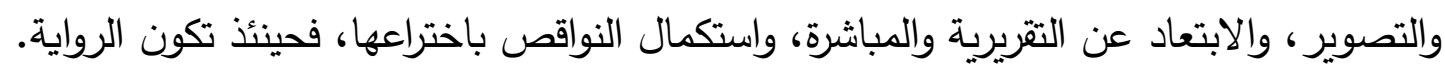

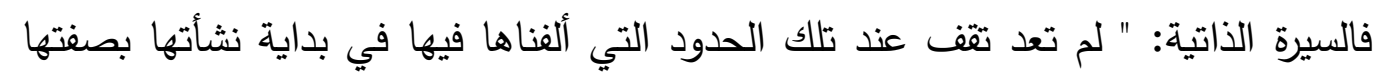

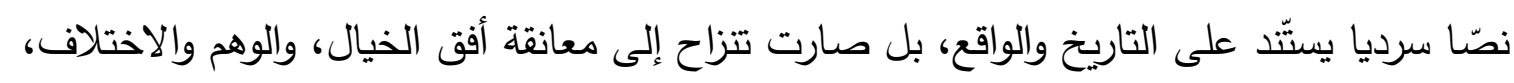

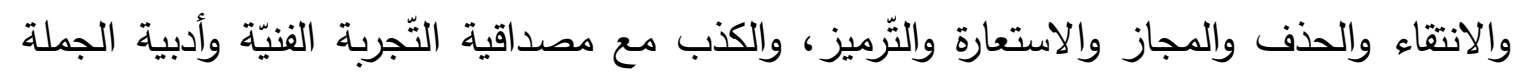

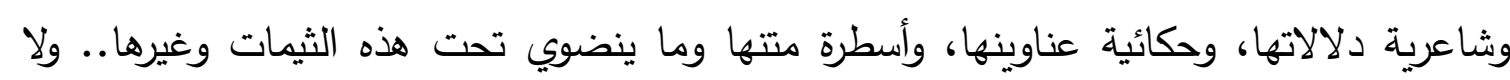

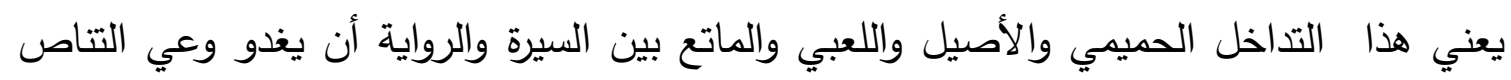

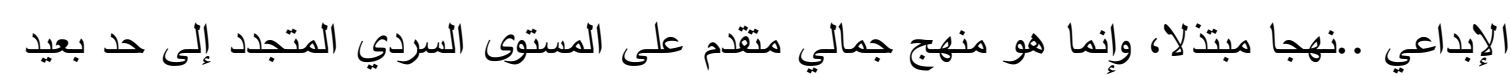

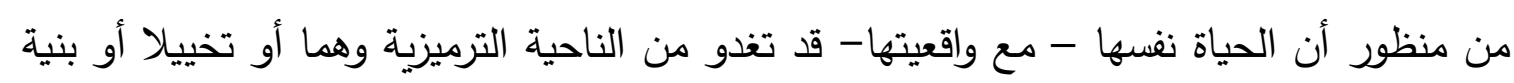

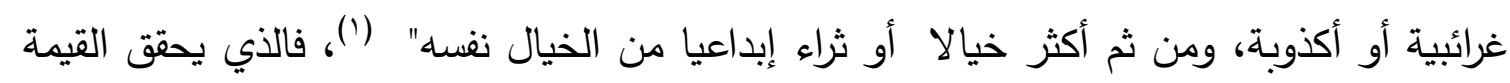

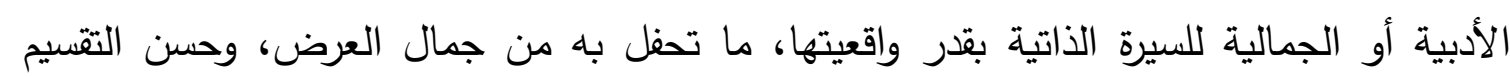
وعذوبة العبارة، وبث الحياة والحركة في تصوير الوقائع والثخصيات.

وفي الوقت ذاته يحدث هذا التداخل - بين السيرة والرواية أو بين الواقع والخيال - خلطا

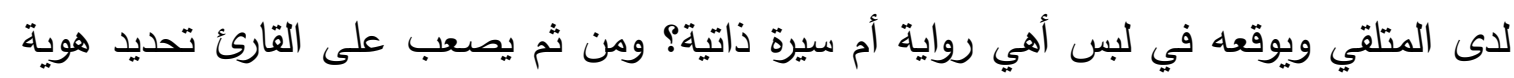

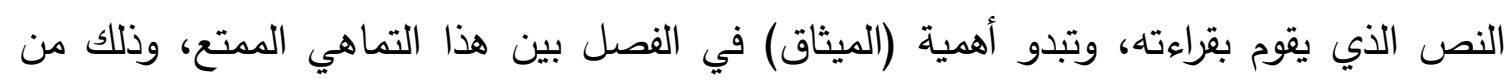

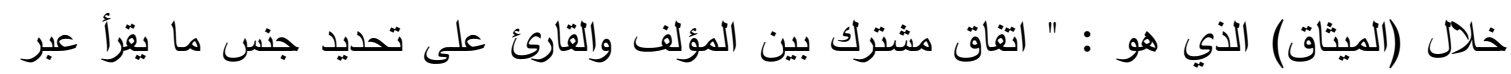

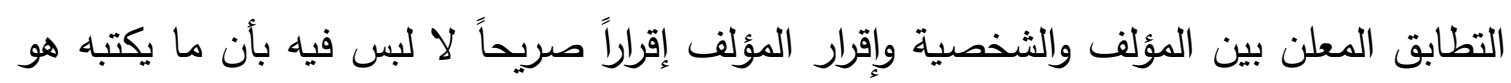

(1)- وهج السرد (مقاربات في الخطاب السردي السعودي)، ص90، حسين المناصرة، إرب، عالم الكتب الحديثة،9 ... ץ م. 
صورة مطابقة لحياته وبناء على هذا الإقرار يدعو المؤلف قارئه إلى التعامل مع النص على أنه (1) سيرة ذاتية لذا فأول ما: " يتبادر إلى أذهاننا عند دراسة أية سيرة ذاتية أن نكثف عن الميثاق السيري

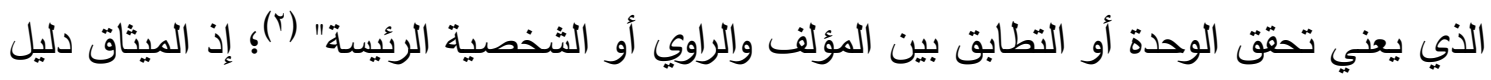

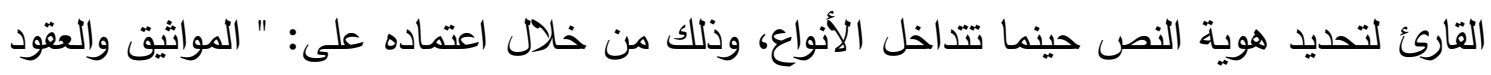

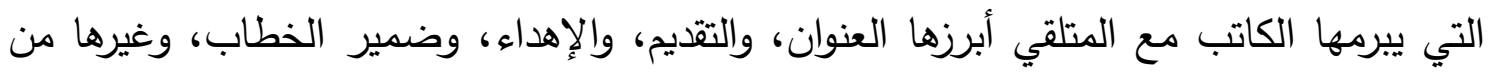

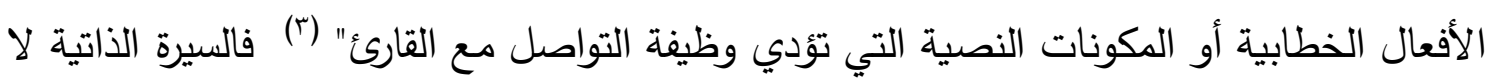

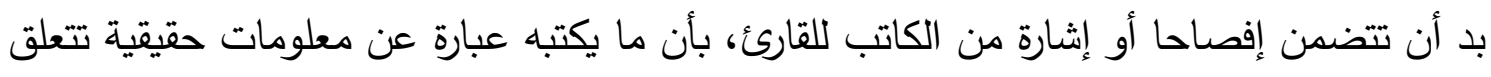
بحياته؛ حتى لا تختلط لديه الأنواع والأجناس. والقارئ لـ(ابن الريف، وابن الكاتب) يجد نفسه أمام عملين يتأرجحان بين السيرة الذاتية

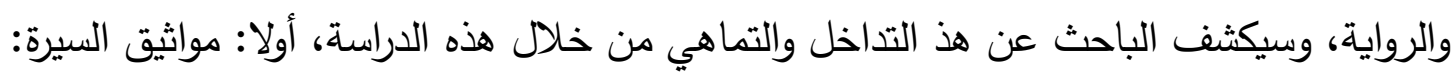

$$
\text { أ- العنوان }
$$

ويبدأ هذا الميثاق بـ(العنوان) فالعنوان من السمات الأولية التي تميز العمل الأدبي وتوضح

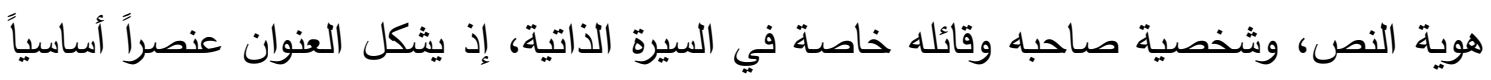

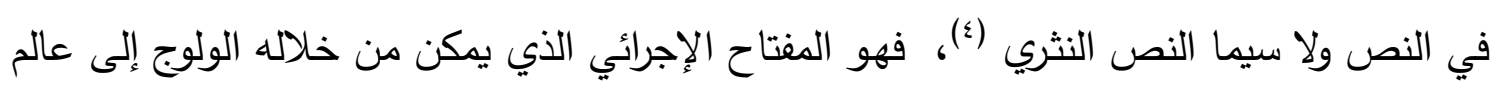

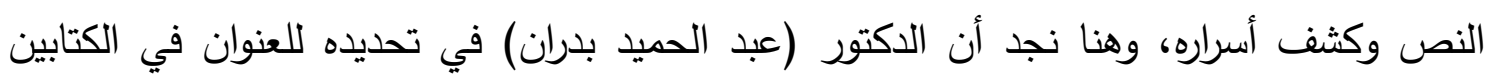
الخاصين بسيرته يركز على نقطتين أساسيتين هما علاقته بالمكان (الريف)، والإبداع (ابن فين

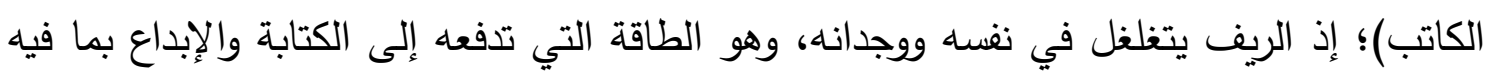
من مظاهر الصفاء والنقاء والجمال: " فعملية الربط بين السيرة الذّاتية وعنوانها وكاتبها حتمية بحكم

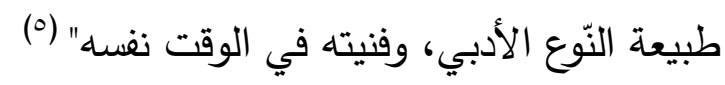

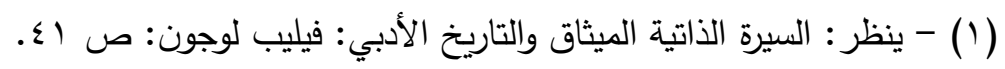

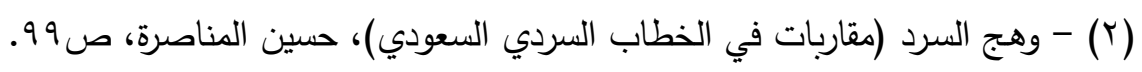

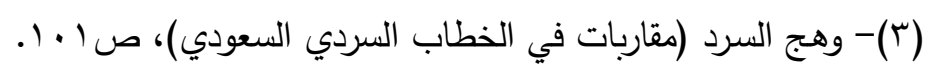

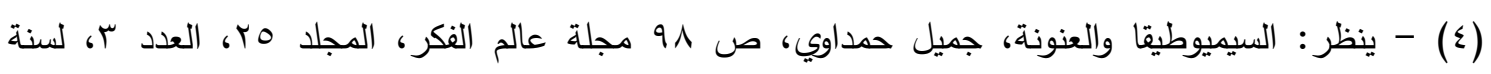

(0)-السيرة الذاتية النسائية في الأدب العربي المعاصر ، أمل التميمي، ص ا9 (1، المركز الثقافي العربي، المغرب،

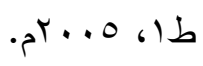




\section{تلداخل النوع الأببي بين السيرة الثاتية والرواية في أدب الدكتور عبد الحميد بلدان}

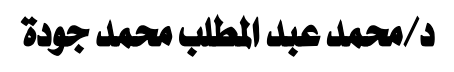

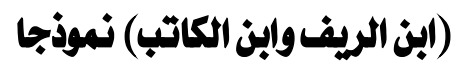

وحينما ننظر إلى العنوان (ابن الريف، وابن الكاتب)، من حيث الميثاق والدلالة على ذاتية

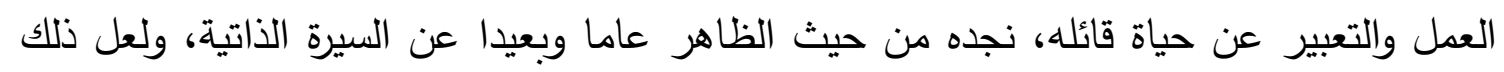

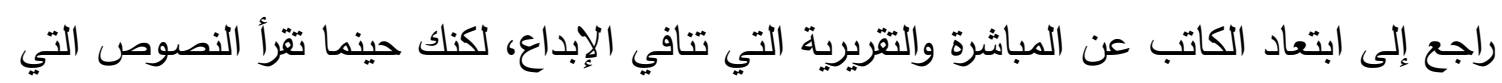

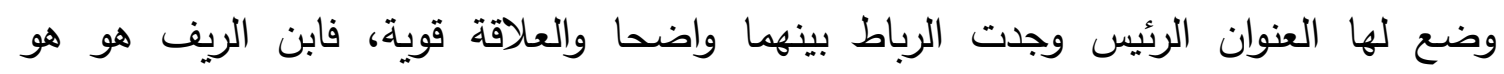

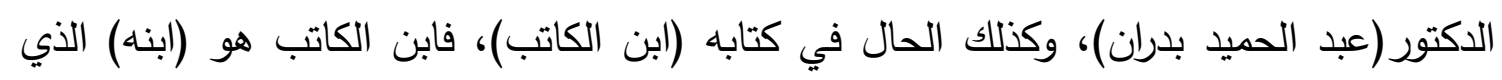

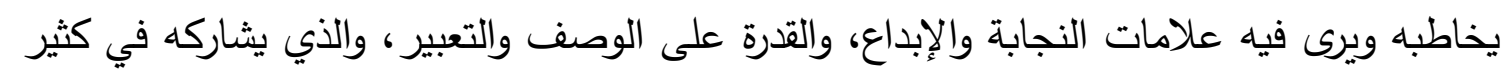

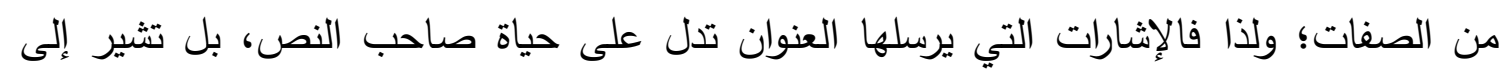

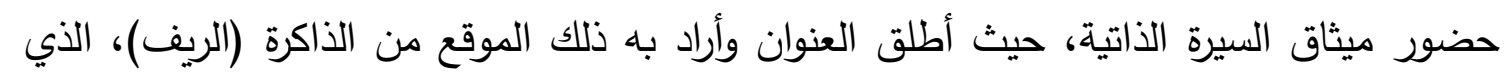

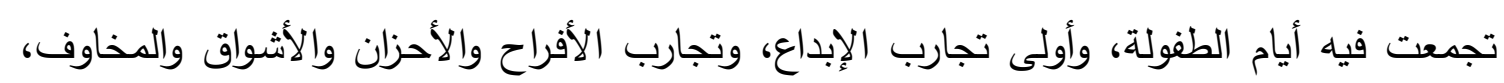
التي أخذت تتوالى عليه. أما عن العناوين الداخلية فقد جاءت في كتاب (ابن الريف) مرتبة كالتالي:(أيام الطفولة،

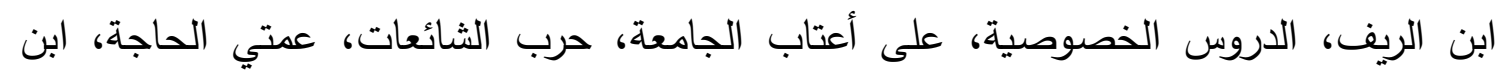

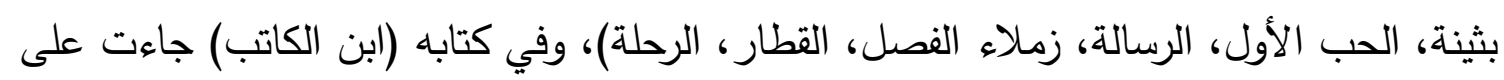

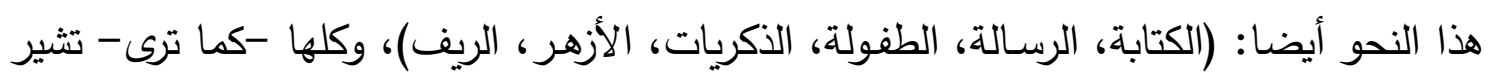

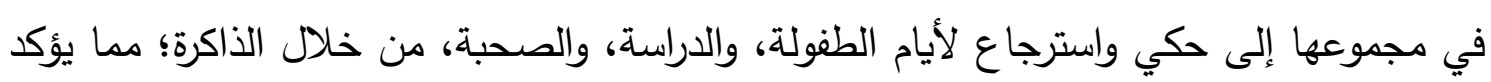
انتماء النص إلى السيرة الذاتية.

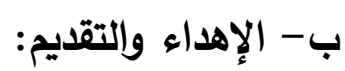

تظهر أهمية (الإهداء) بوصفه ميثاقا من المواثيق الموجهة للنص السير ذاتي، إذ هو عتبة

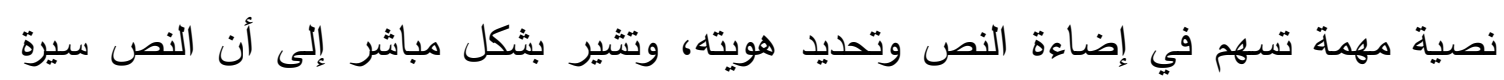

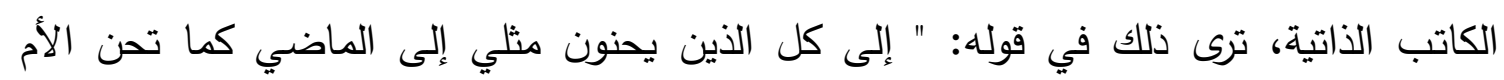

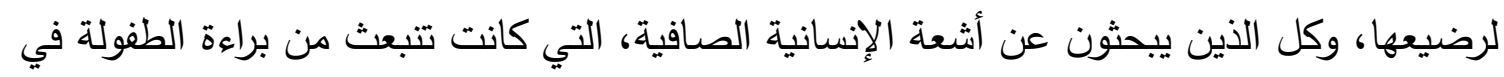

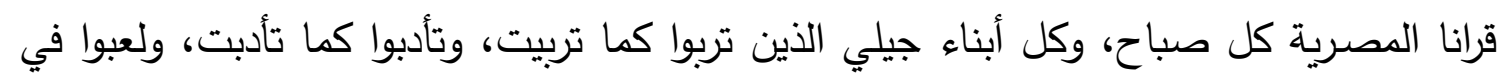

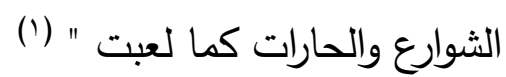
ففي إهدائه - كما رأيت- يخص شريحة معينة من الناس وهم الذين يشاركونه عشق الريف وصفاءه، وفطرته، فميثاق الإهداء يؤكد منطق الحكي الذي هو أساس السئس السيرة الذاتية، ومنطق

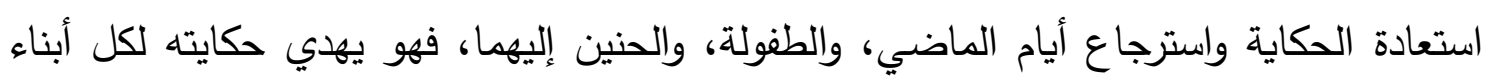
جيله ورفاقه ممن يعثقون الريف ويقدسون صفاءه.

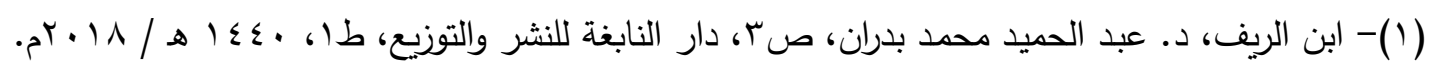


لكنه في تقديمه لـ (ابن الكاتب) كان أكثر شفافية ووضوحا حيث يقول: " ولم يدر في خلدي

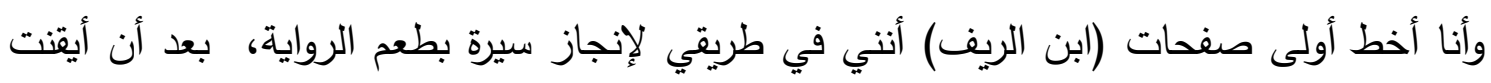

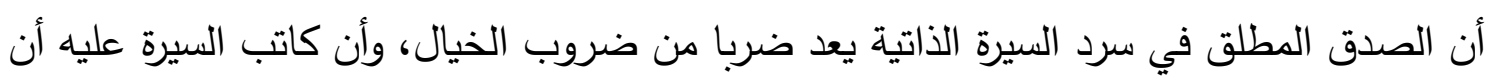

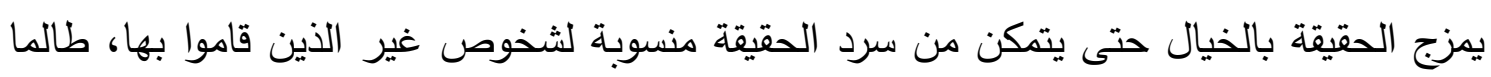

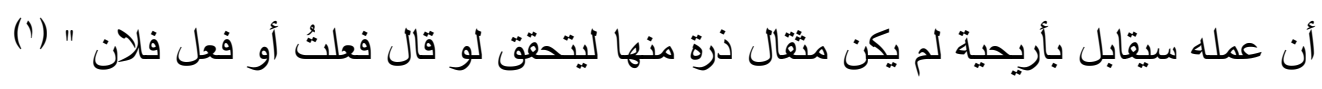
فالكاتب ينص صراحة على أنها (سيرة ذاتية) ويقر إقرارا بذاتية عمله (ابن الريف، وابن الكاتب)، ومن ثم يرجح هذا الميثاق كفة السيرة الذاتية في الجوهر (الحقيقة)، وكفة الرواية (الخيال)

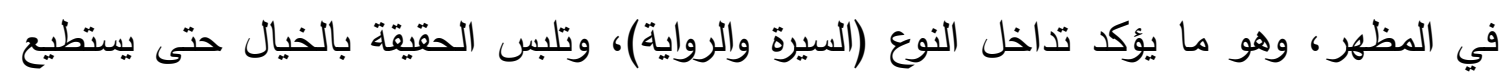
الإفصاح عن مكنوناته.

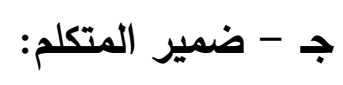

إن توظيف: " ضمير المتكلم (أنا)، في هذا النوع من الكتابة، يشير إلى خصوصية الذات

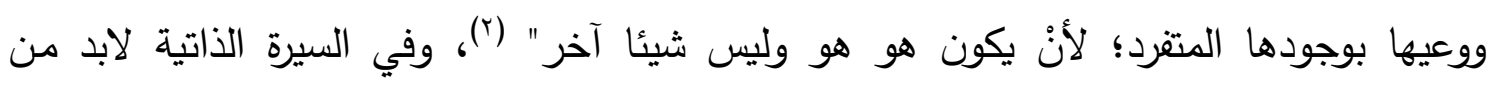

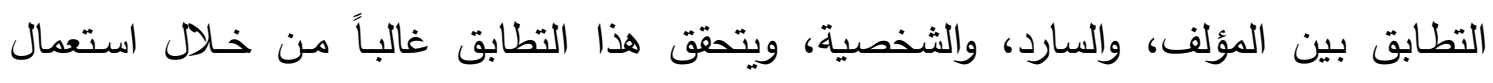

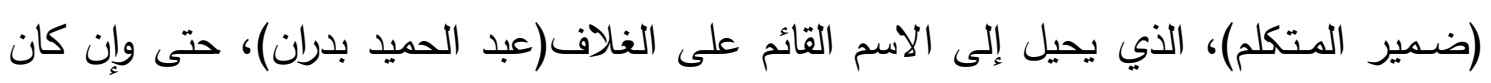

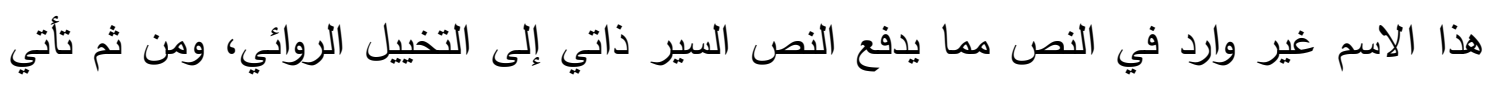

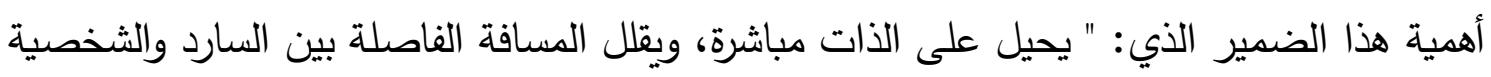

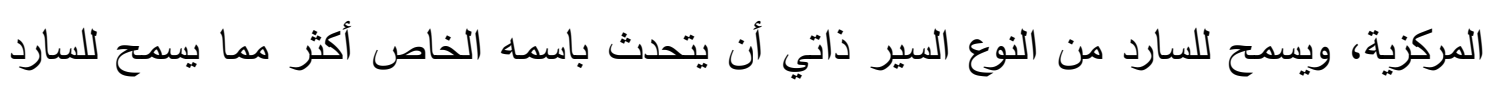

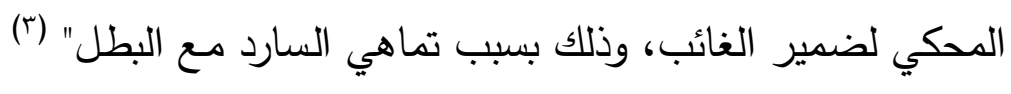
"وليس سواء ضمير يسرد ذاته وآخر يحكي سواءه، ضمير منطلقه من الداخل نحو الداخل

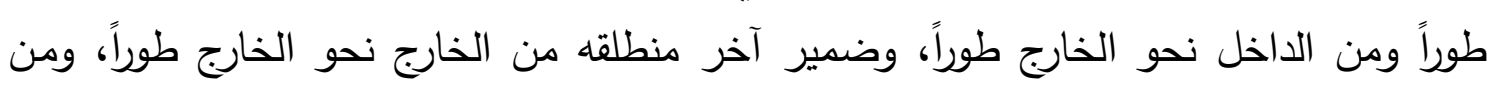

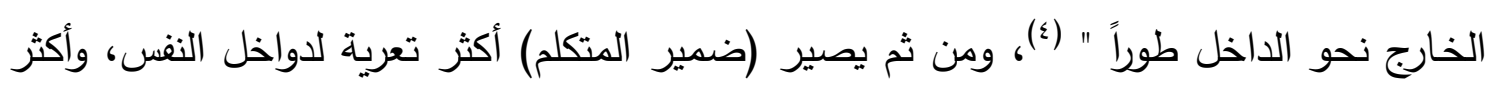

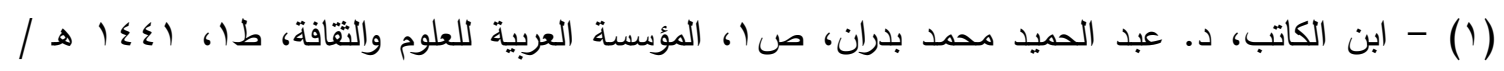
. 19

(Y)- ينظر : سرد الذات -فن السيرة الذاتية، عمر منيب إدلبي ص. • ج، دائرة الثقافة والإعلام، الثارقة، الإمارات

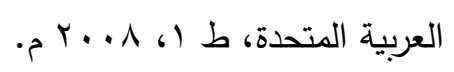

سيرة جبرا الذاتية في (البئر الأولى وشارع الأميرات) خليل شكري هياس، صنا، صاله، من منشورات اتحاد

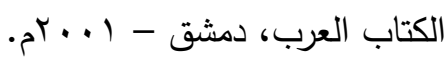

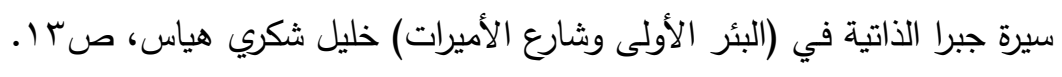




\section{تلداخل النوع الأببي بين السيرة الثاتية والرواية في أدب الدكتور عبد الحميد بلدان}

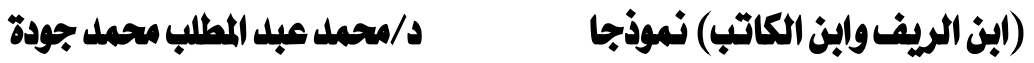

دلالة على ذاتية السرد، وذلك بما له من قدرة على التذكر، والاسترجاع، والتحليل، والاستبطان الذاتي أو المباشر للشخصية الرئيسة. وهو ما فعله الدكتور (عبد الحميد بدران) في كتابه (ابن الريف) حيث اتخذ ضمير المتكلم

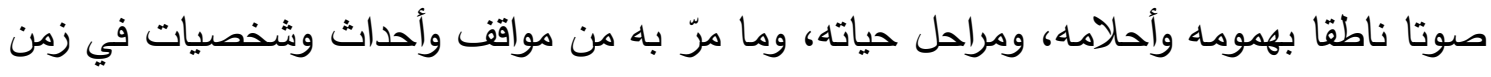

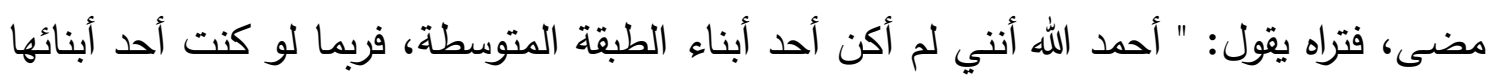

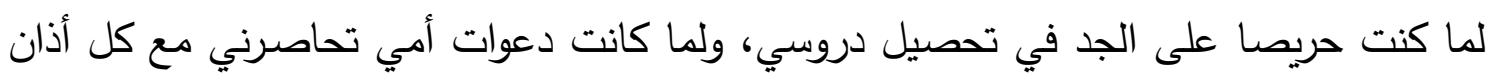

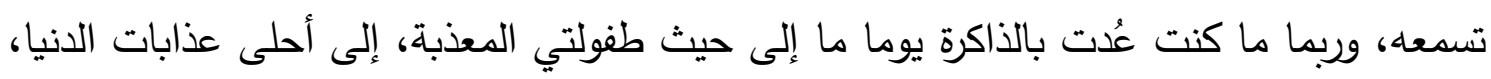

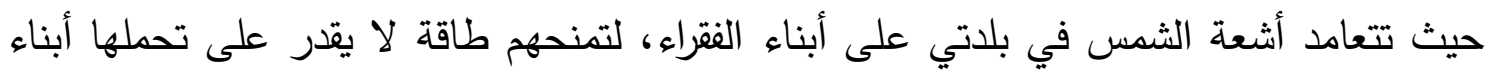
الأغنياء مهما كانت قوة مظلاتهم وصلابة أجسادهم.

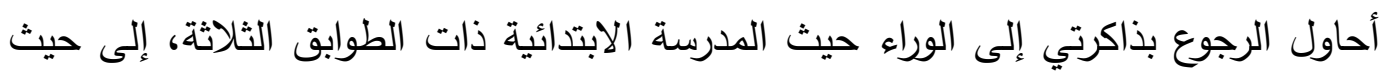

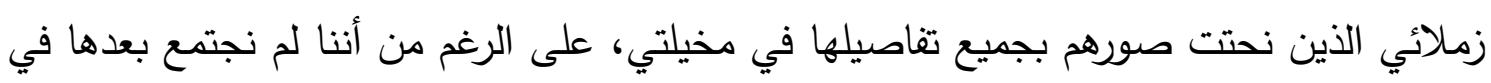

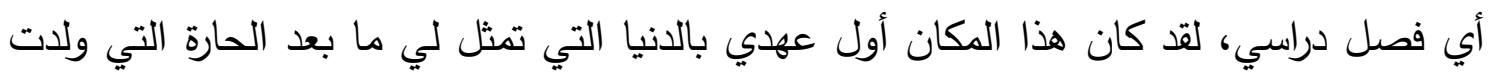
فيها" (1) في (1)

فكما ترى يقوم بناء السرد في (ابن الريف) على ضمير المتكلم المفرد الذي هيمن على

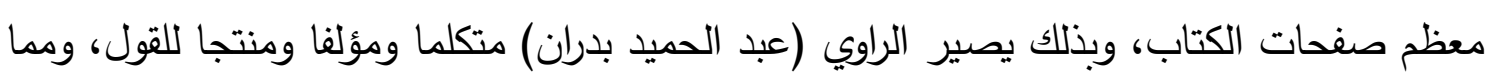
لا شك فيه أن صيغة المتكلم -كما ذكرت- هي أكثر الصيغ دلالة على التماهي والتطابق بين

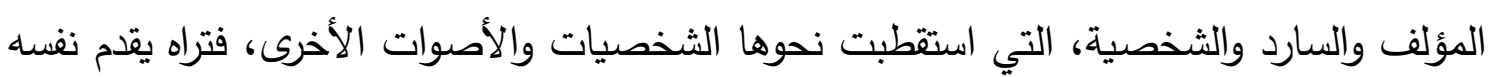
من البداية بأنه على دراية كاملة بالأحداث التي يقوم بتدوينها، مما يؤكد أنها قصة التهات حياته.

أما عن الجزء الثاني أو الحلقة الثانية من سيرته الذاتية في كتابه (ابن الكاتب) فقد حفل بتبادل رشيق وممتع في مواقف الضمير السارد ومواقعه، ففي الكثير من المواقع والمواقف السردية

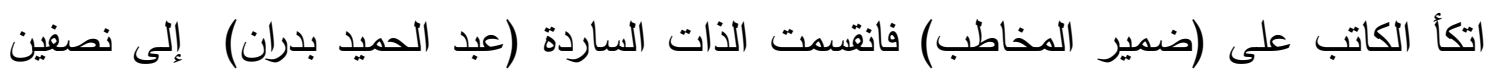

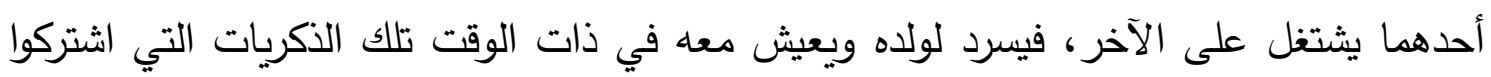

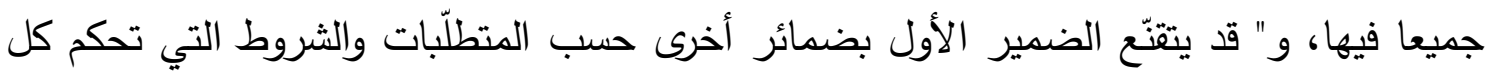

قصيدة سير ذاتية " (r)

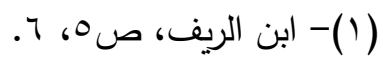

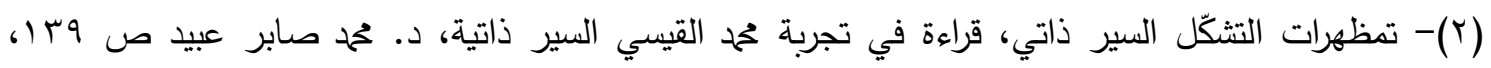

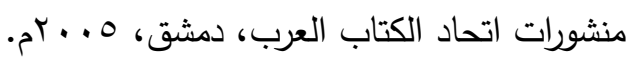


وتستطيع أن ترى ذلك في قوله:" أعلُُ يا بني أنك تتوق لأن تكون ملء السمع والبصر في

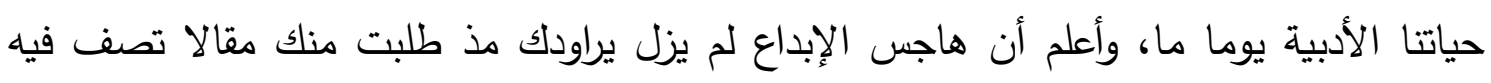

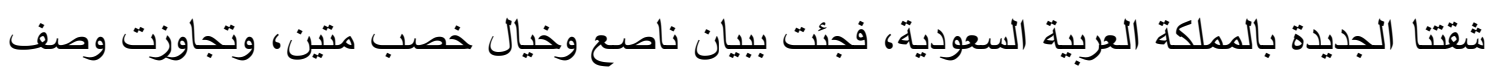

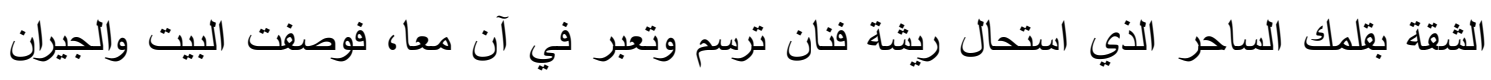

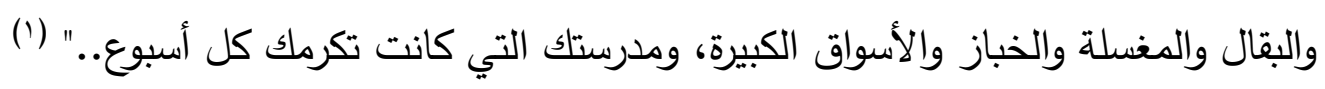

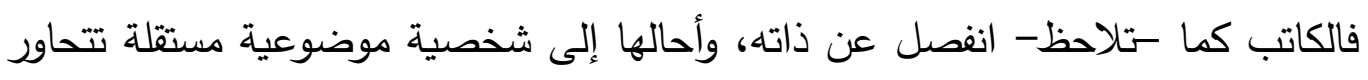

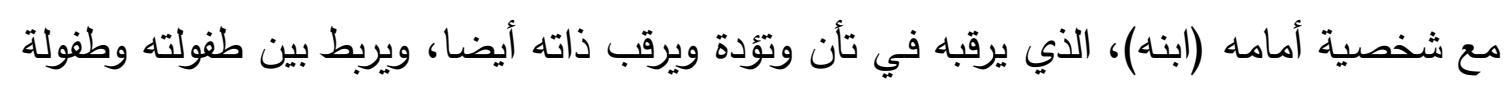

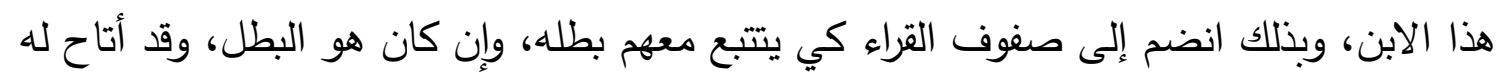

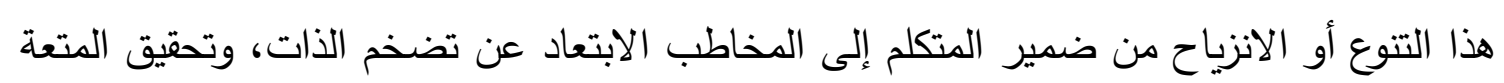
والتشويق للقارئ، الذي أخذ يتابع هذه المواقف والمحاورات. وفضلا عن ذلك يمكن أن يقال إن الدكتور (عبد الحميد) أغفل اسمه في كتابه (ابن الكاتب)

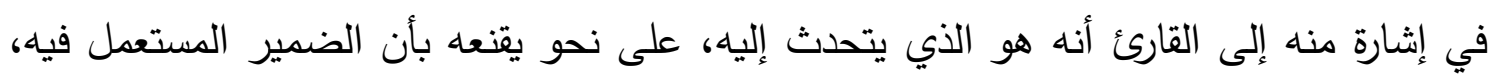

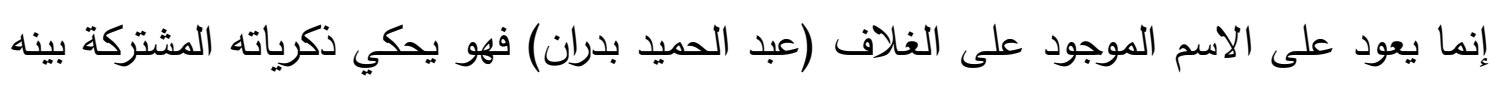
وبين ولده الذي يرى فيه صورته وطفولته.

كما أن استخدام الكاتب لضمير المخاطب لا يعني اختفاء ضمير المتكلم، فهو حاضر في

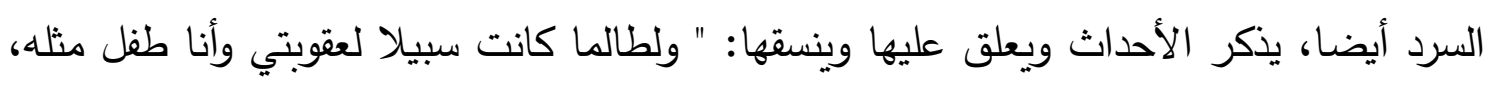

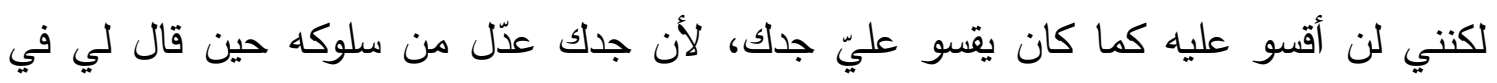

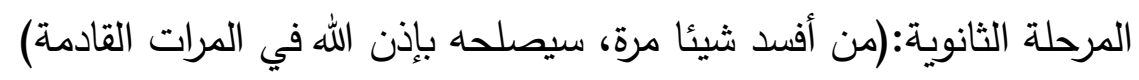

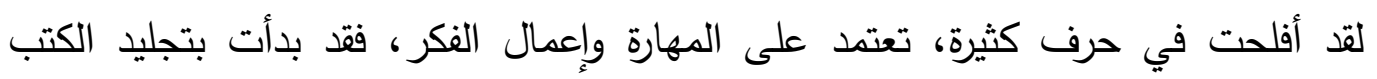

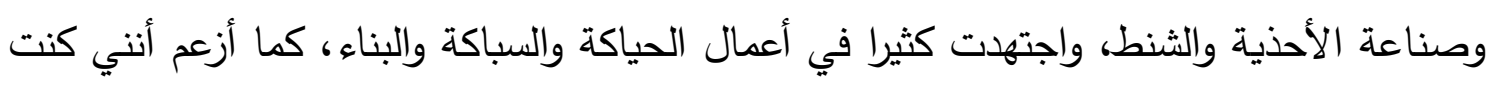

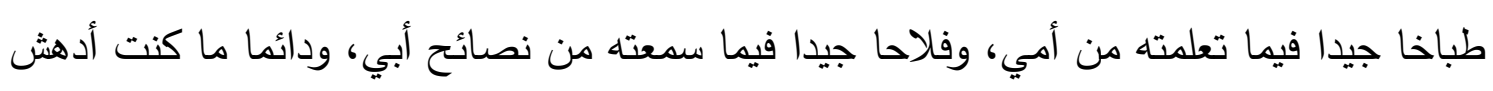

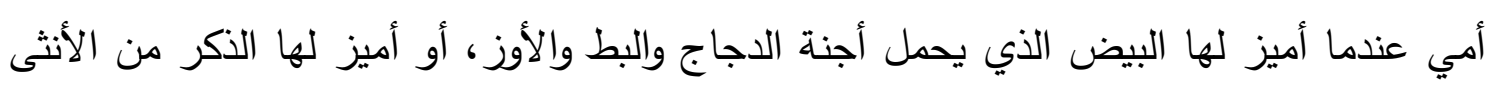

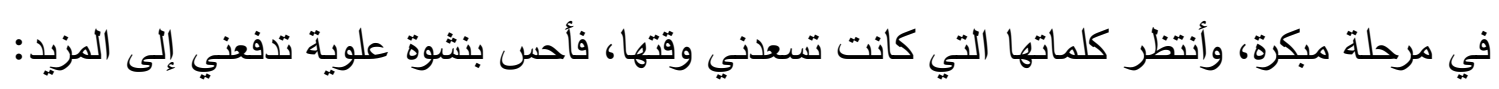

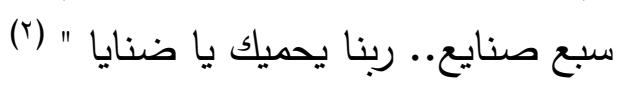




\section{تلداخل النوع الأببي بين السيرة الثاتية والرواية في أدب الدكتور عبد الحميد بلدان

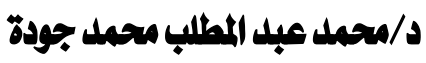

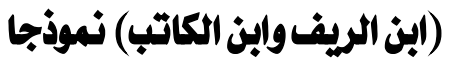

فضمير المخاطب كما رأيت يستلزم حضورا لمتكلم يحاور ، ويخاطب، ويفسر، ويعلق، لذا يمكن القول إن ضمير المتكلم المفرد يتيح للمترجم لذاتـه إمكانية تحقيق التطابق بين المؤلف، والثخصية، والسارد بصورة مباشرة، مما يؤكد توافر شروط السيرة الذاتية ومواثثها بحد

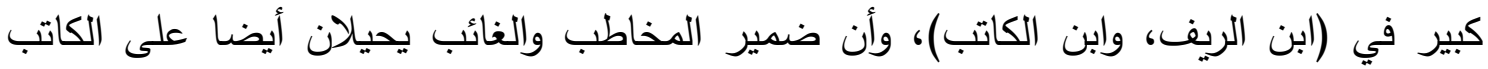
بطريقة غير مباشرة، ويؤكدان استرجاع الكاتب لقصة حياته، وخاصة بعد أن علمنا ذلك من خلان خلال القرائن السابقة (العنوان، والإهداء، والتقديم). ولعل استخدام الكاتب لضمير المخاطب في كتابه (ابن الكاتب) يعود إلى رغبة الكاتب في الاقتراب من قارئه وابتعاده عن الذاتية الفجة، وكأنه يوجه خطابه إلى قارئه بصورة غير مباشرة،

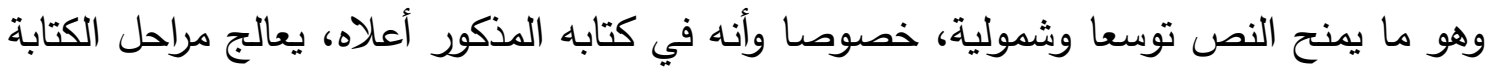
والإبداع في حياته، فهو يشرك قارئه من خلال هذا الضمير الحواري ويوجها فئه إلى تقنيات الكتابة والإبداع.

$$
\text { د-النص: }
$$

وبتأمل النص نجد إثارات صريحة وواضحة، تؤكد انتمائية النص إلى السيرة الذاتية من

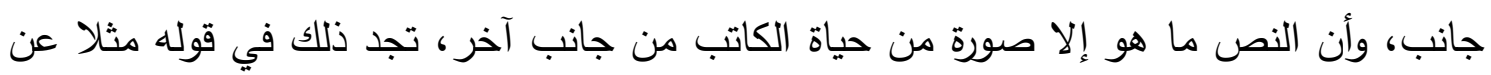

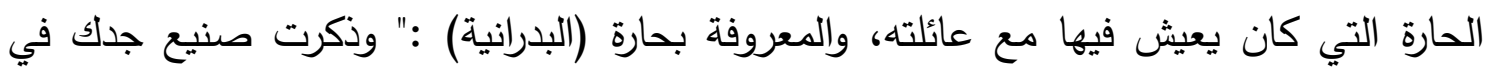

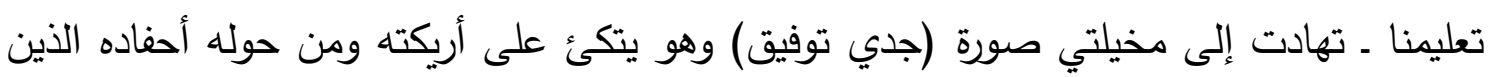

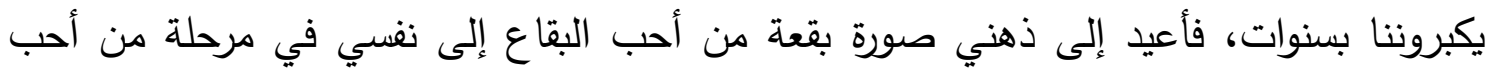

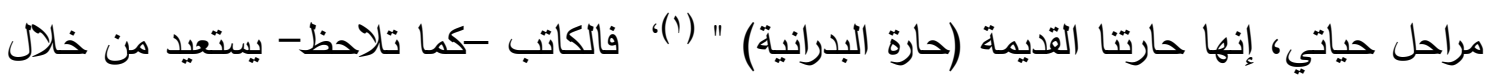

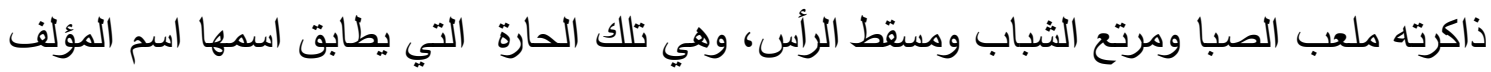
المعلن على غلاف الكتاب.

وتضمّن النص كنلك تلفّظاً صريحاً بلقب (البدرانية) أثناء حديثه لولده عن جده حيث يقول: " كان جدك أحد البدرانية الذين من الله عليهح بوفور العقل وحصافة الرأي، حيث أتم حفظ القرآن

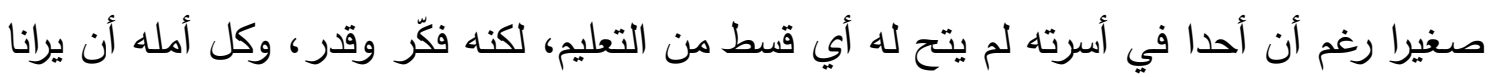

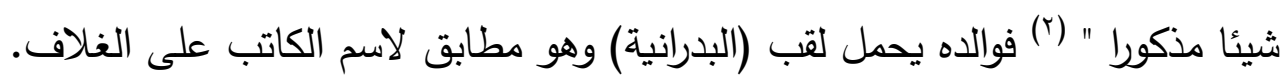
ونص (ابن الريف) تضمن هو الآخر إشارات تدل على التطابق بين، المؤلف، والسارد،

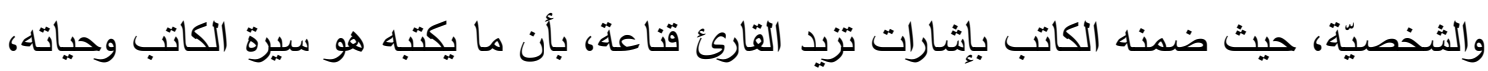

$$
\text { (Y) (Y)- ابن الكاتب، صوه، صوه. }
$$


وذلك كحديثه عن أيام الدراسة والتحاقه بالجامعة واسترجاعه لتلك الذكريات أثناء لقائه بأحد الزملاء: " ياه ... وصلت فين في التعليج؟ . أنا معيد في الجامعة.

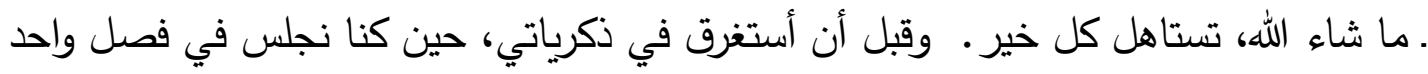

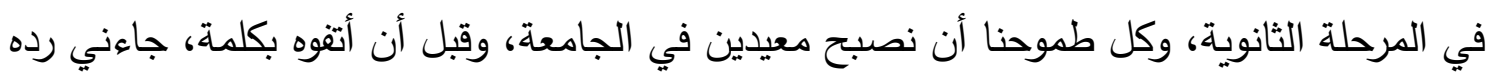

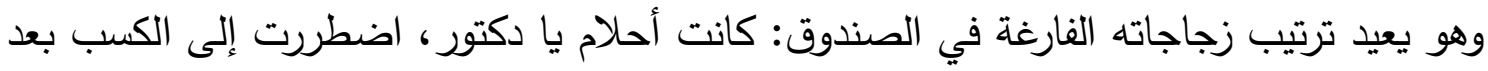

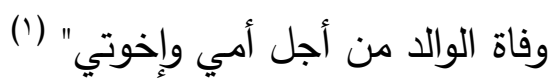
ومن ذلك أيضا:" ومع إذاعة موعد المناقثة، عرف الفرح الحقيقي طريق بيتا، وأقبل

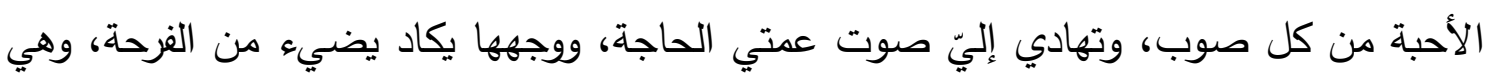

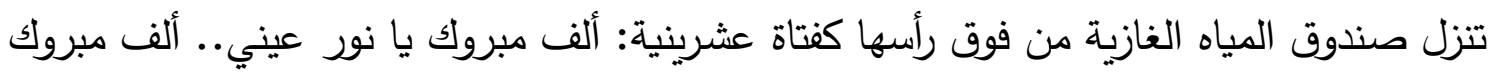

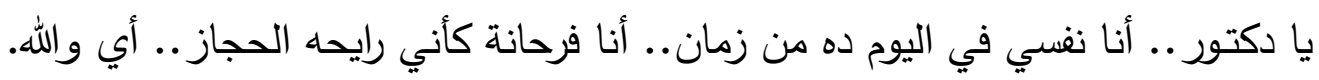

كانت هذه هي المرة الأولى التي تقول لي فيها عمتي (يا دكتور)، بدلا من (يا ولد)، وكانت

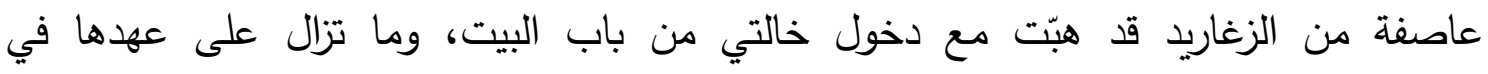

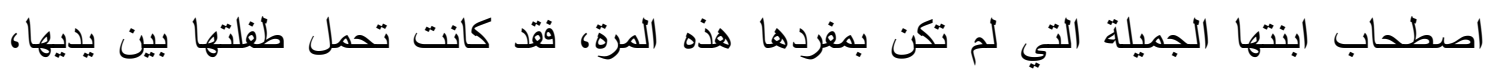

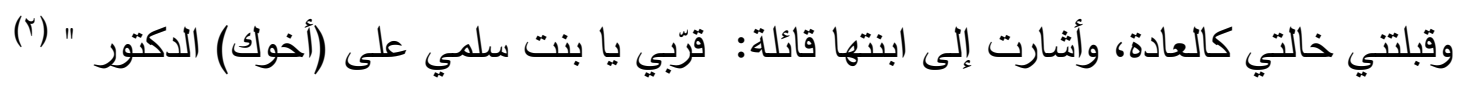

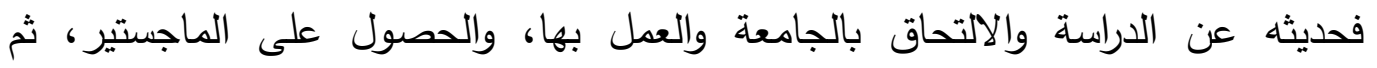

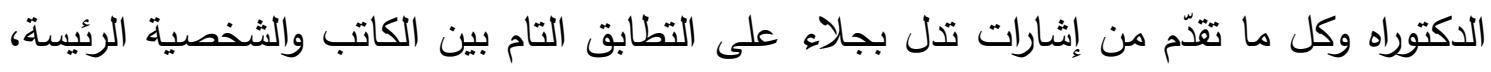
وبذلك يتحقق عنصر من عناصر السيرة الذاتيّة في كتابيه (ابن الريف، وابن الكاتب).

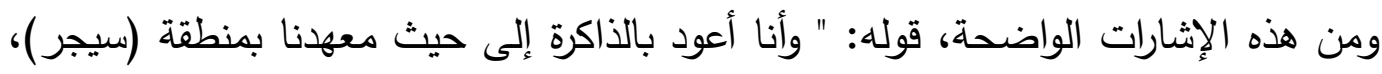

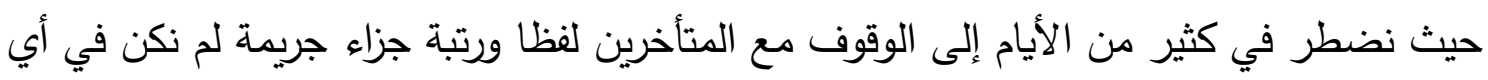

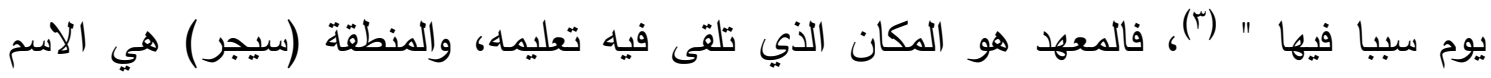

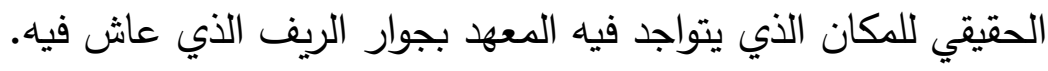

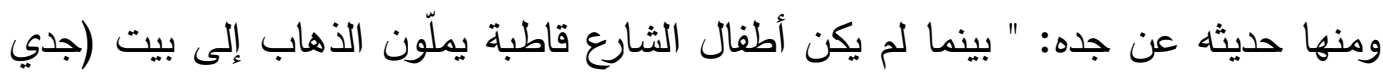
توفيق)، الذي لم يعبس في وجه أحدنا يوما من الأيام... وكان (سيدي توفيق) مصدر العنان الحنان الدائم

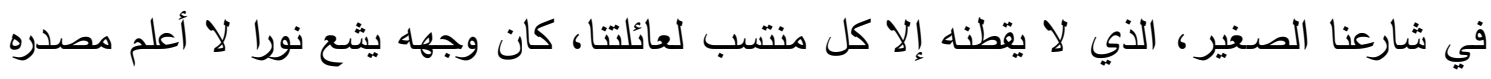

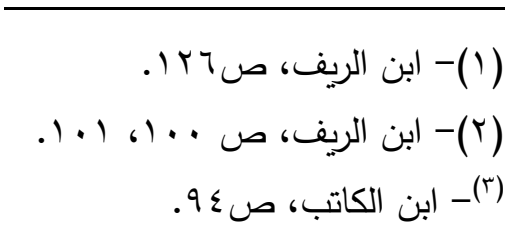




\section{تلداخل النوع الأببي بين السيرة الثاتية والرواية في أدب الدكتور عبد الحميد بلدان \\ دمحمل عبد المطلب محعل جودة \\ (ابن الريفوابن الكاتب) نموذجا}

على وجه الدقة، فهل كانت ناصيته ولحيته وأسنانه البيضاء؟، أم أنه نور القران الذي يحمله في

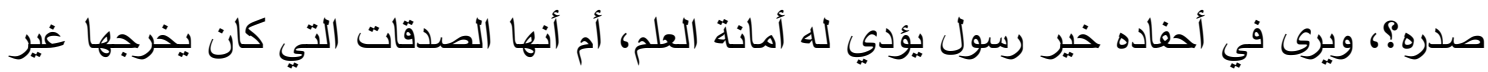

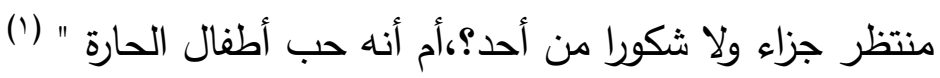

ويمكن القول إن شخصية الدكتور / عبد الحميد بدران، هي شخصية المؤلف، وهي شخصية

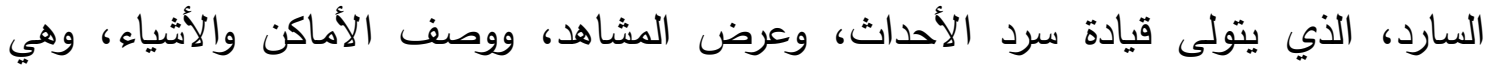

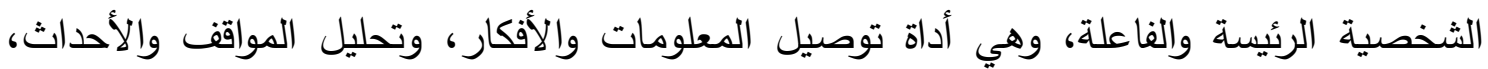
وهي الثخصية التي تدور في فلكها الثخصيات الأخرى، وفي ذات الوقت تروند ترديل إليه ردود أفعال الآخرين فتترك أثرا في حياته. 


\section{دوافع كتابة السيرة الذاتية لايه}

\section{لماذا كتب الاكتور (عبد الحميد بدران) سيرته الذاتية؟}

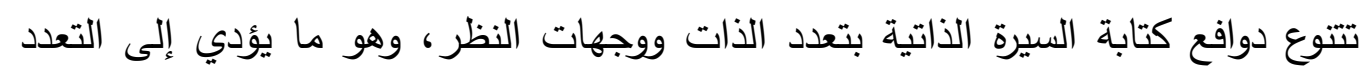

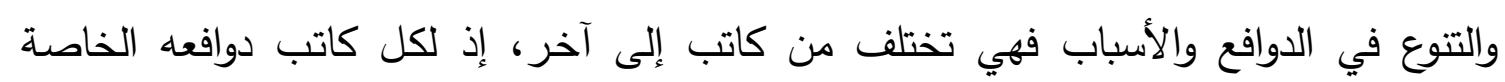

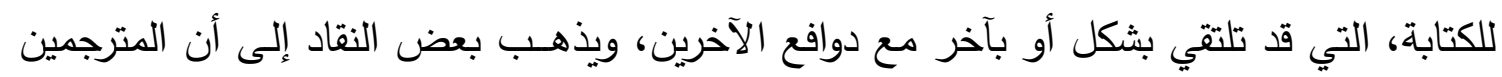

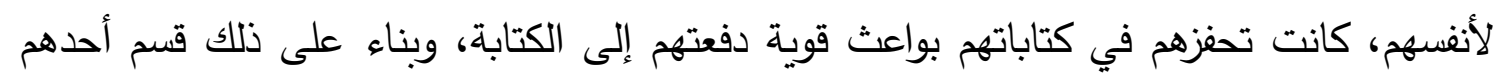

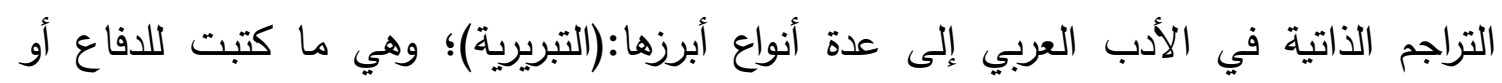

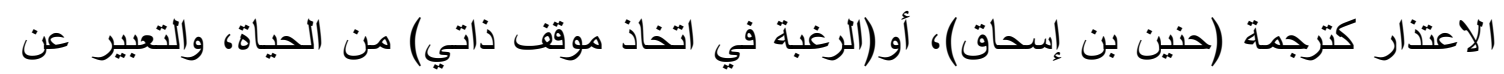

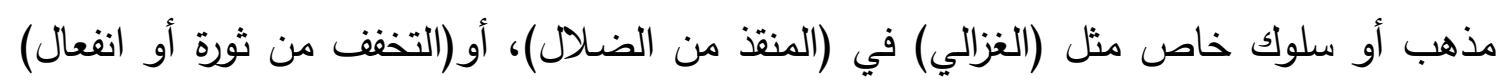

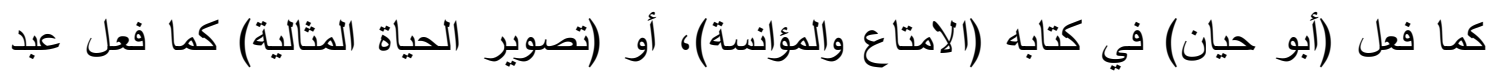

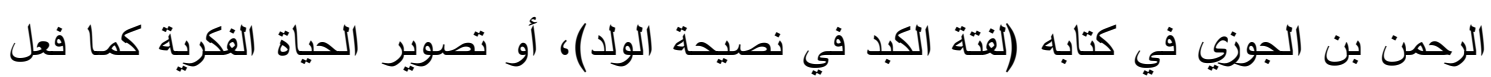

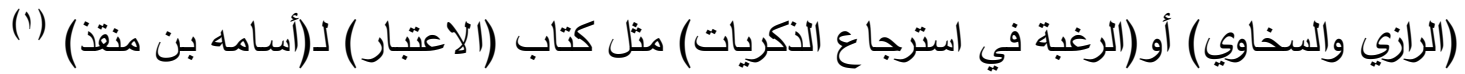

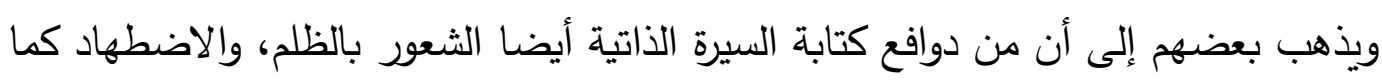
جاء في كتاب (الأيام) لطه حسين، وقد يهدف الكاتب من وراء تدوين سيرته الذاتية أن يقدم للقراء

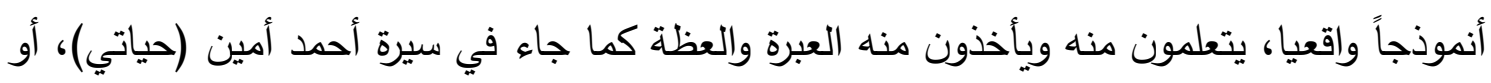

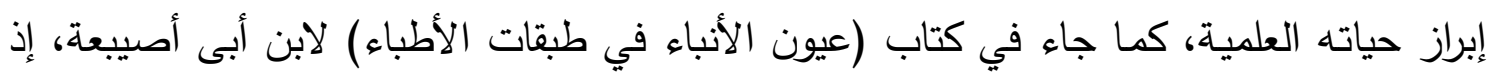

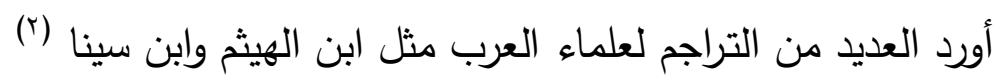

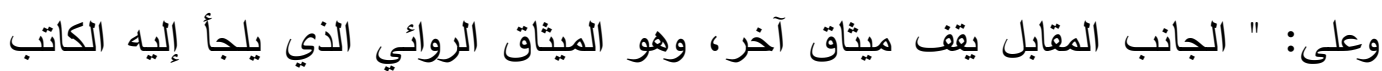

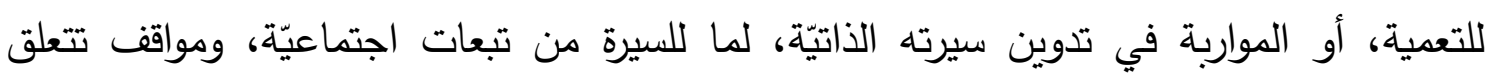

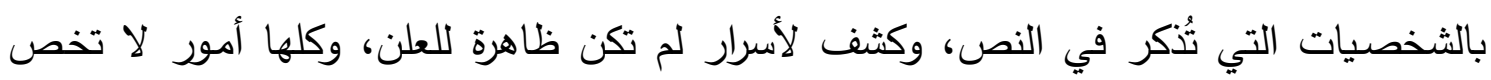

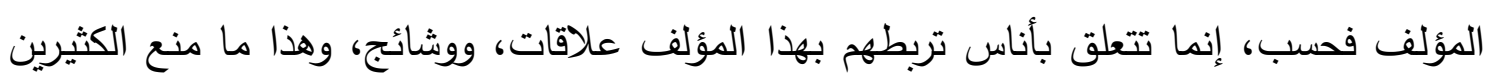

( (1)- الترجمة الذاتية في الأدب العربي الحديث، د. يحيى إبراهيم عبد الدايه، صبrك-هب، دار إحياء التراث

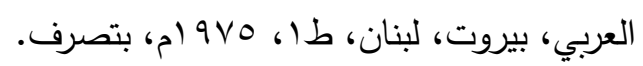

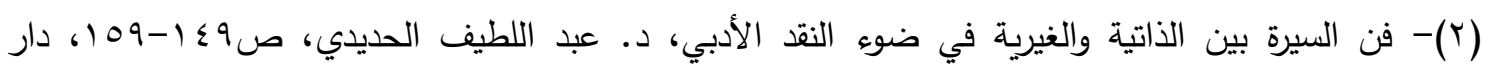

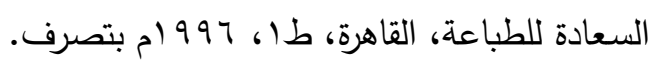




\section{تلاخل النوع الأببي بين السيرة الداتية والرواية في أدب الدكتور عبد الحميد بلدان}

\section{د/محمل عبد المطلب محمل جودة}

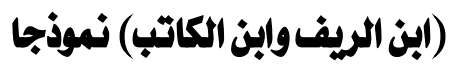

من تدوين سيرهم الذاتيّة، أو اللجوء إلى الإعلان عن ذلك، فتقتنعوا وراء التقنيّة الروائيّة، وعرضوا

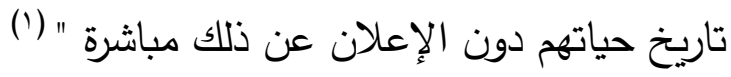

وبتتبع سيرة الدكتور (عبد الحميد بدران) الذاتية في كتابيه (ابن الريف، وابن الكاتب)، نجد

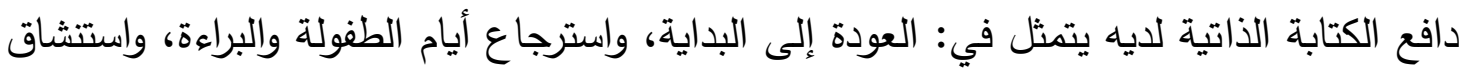

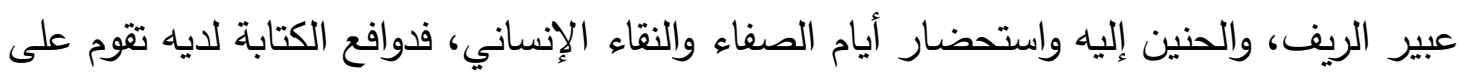

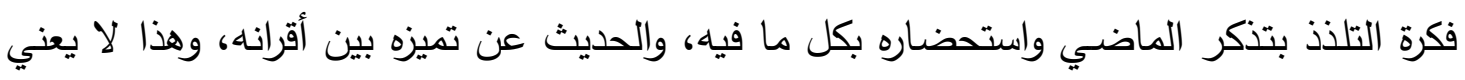

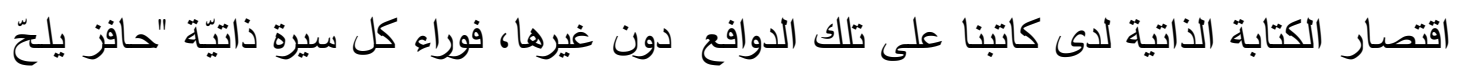

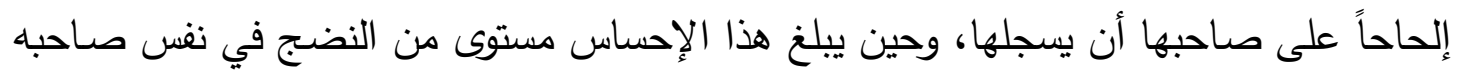

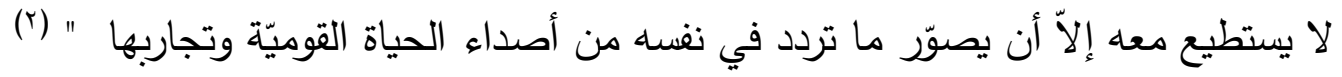

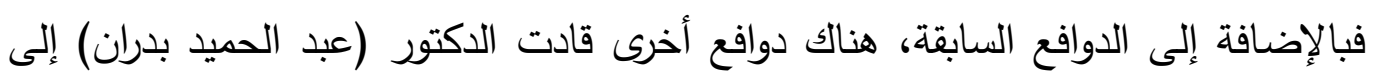

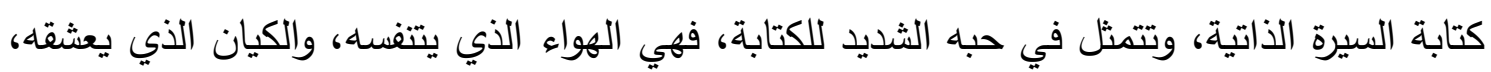
ومن ثم فإن من دوافع كتابة السيرة الذاتية لديه أيضا تحقيق المتعة الفنية، فقد: " يجد الكتّاب لكتيداه

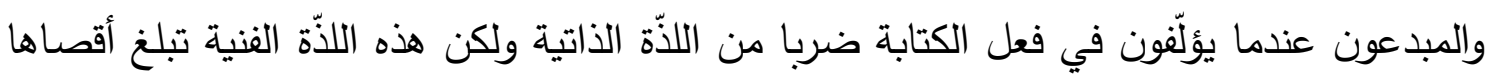
في كتابة السيرة الذّاتية. ذلك أن كاتب السيرة الذّاتية يتلذّذ باستحضار الذكريات السعيدة التّتي عاشها.

إن فعل الكتابة في هذا الجنس الأدبي هو فعل استحضار للذّكريات واستعادة لماض بعيد

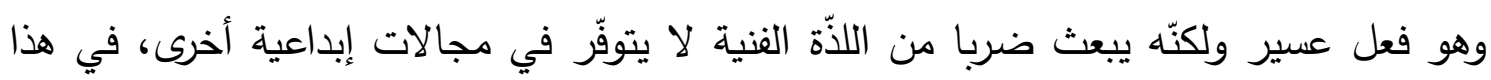

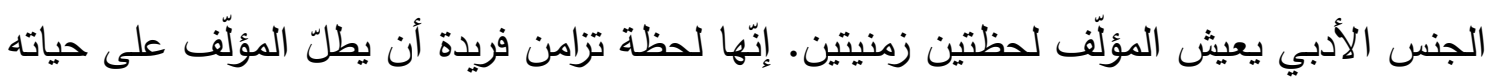

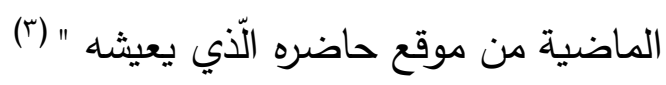
وقد صرح بذلك الدكتور (عبد الحميد بدران) في كتابه (ابن الكاتب) قائلا: " لم يدر في دوانه

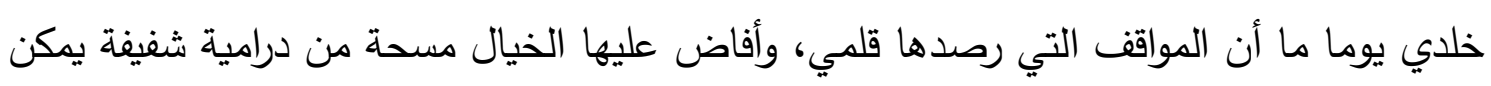

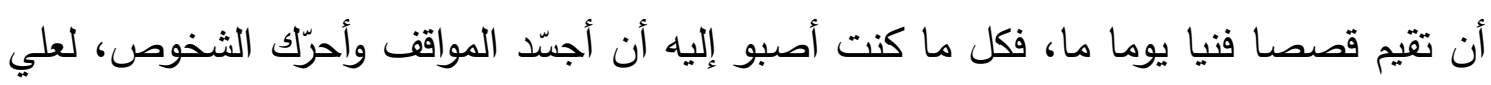

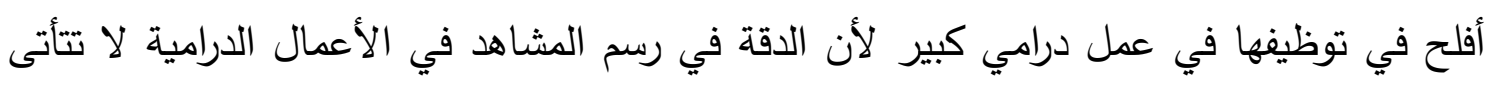

(')- رواية السيرة الذاتية في أدب توفيق الحكيم دراسة نقديّة تحليلية، إعداد سامر صدقي محم موسى، ص الج،

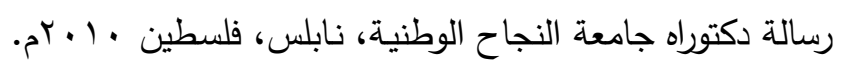

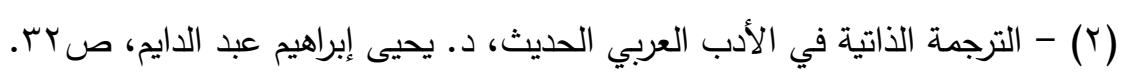

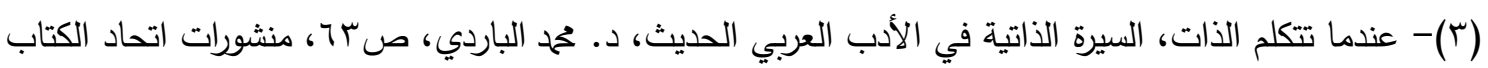

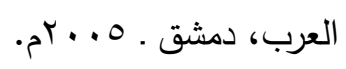


في العمل الكبير دفعة واحدة، ولو حدث ذلك جدلا، فإن الأمر سوف ينتج مشاهد درامية باهتة...

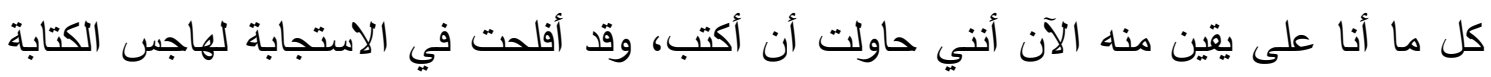

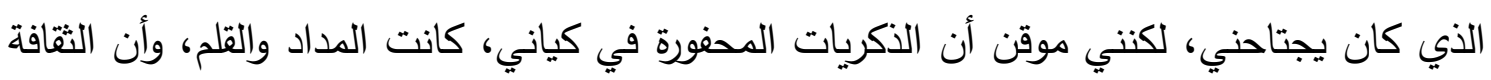

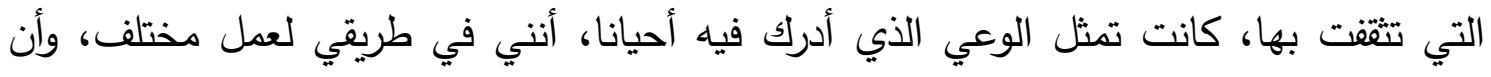

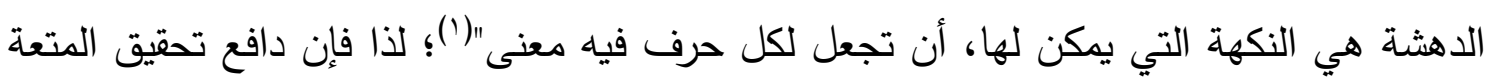
الفنية وإبراز الموهبة الأدبية، يأتي في مقدمة دوافع كتابة السيرة الذاتية لاى الدكتور لئه (عبد الحميد

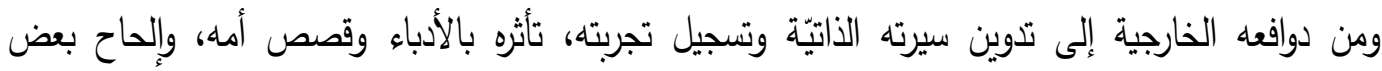

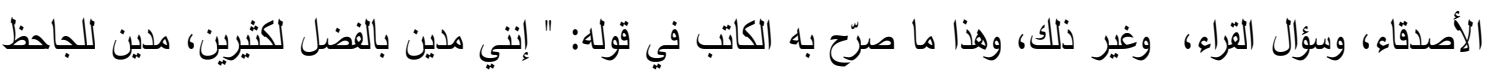

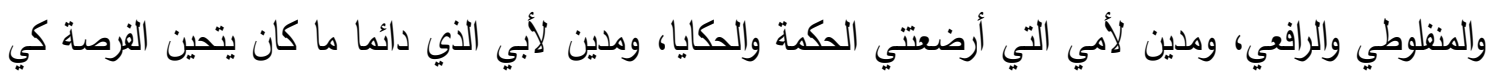

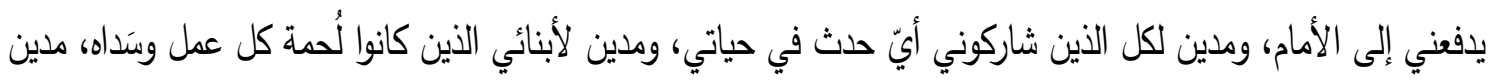

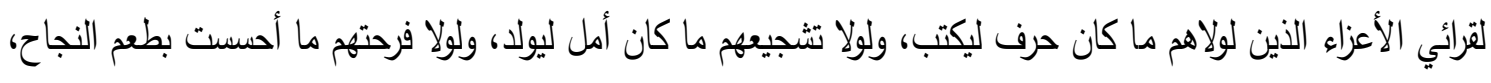

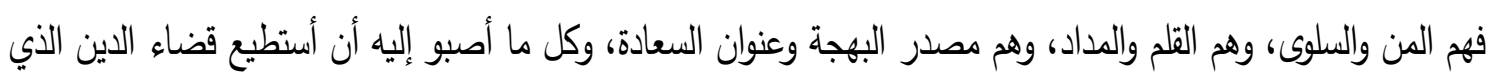

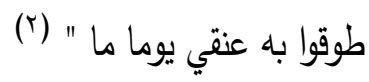
فهناك روابط تجمع بين كاتب السيرة وبين قرائه؛ لأنه يحثثه " عن دخائل نفسه وتجارب حياته، حديثاً يلقى منا أنناً

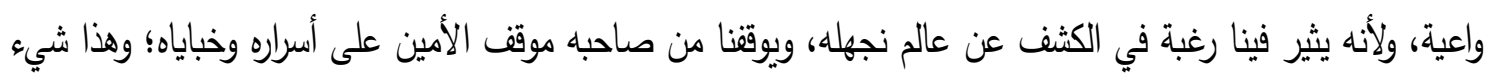

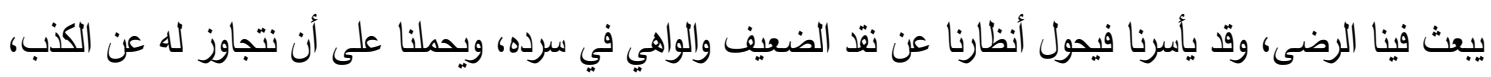

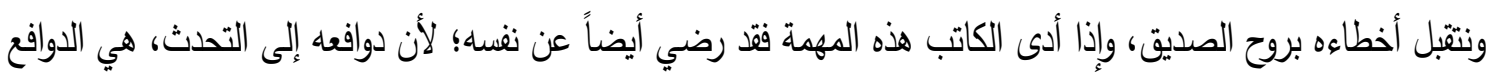

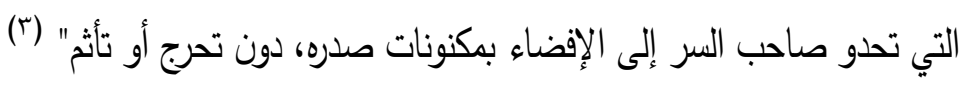

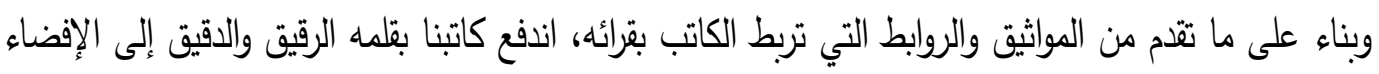

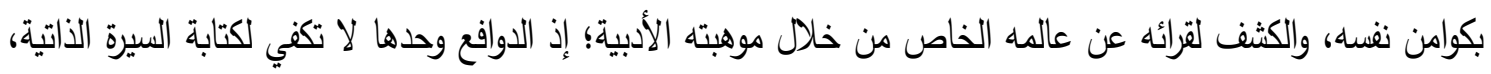

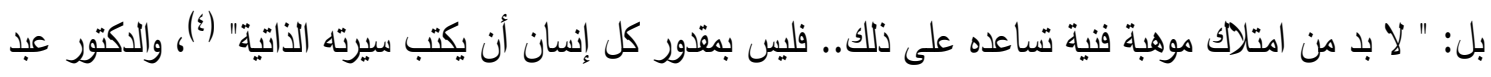

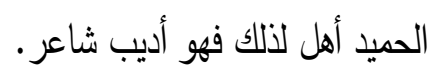

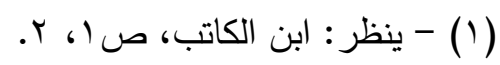

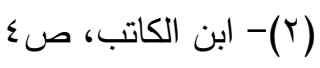

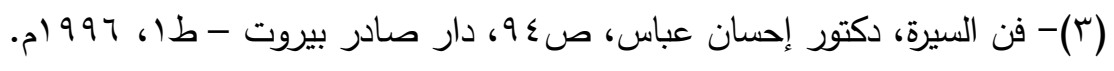

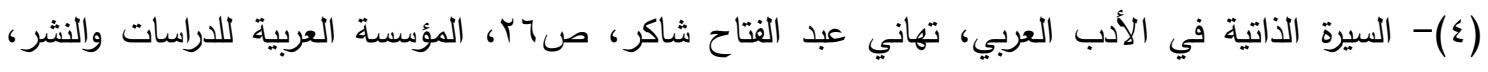

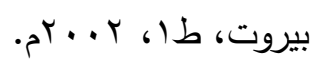




\section{تلاخل النوع الأببي بين السيرة الداتية والرواية في أدب الدكتور عبد الحميد بلدان}

\section{د/محمل عبد المطلب محمل جودة}

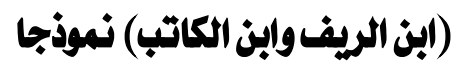

الصراع ونجوى الذات

لا تخلو نفس إنسان من الألم والصراع، سواء أكان هذا الصراع بين الإنسان وذاته، وهو ما

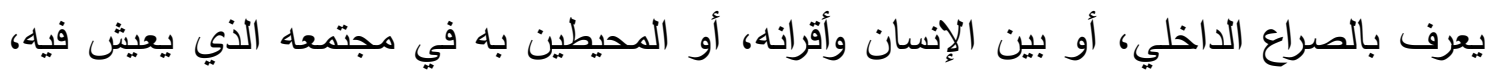

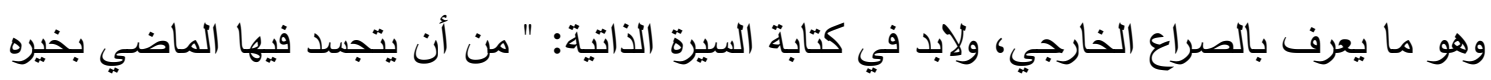

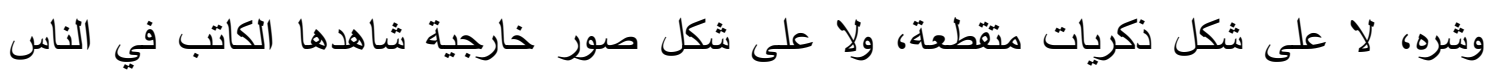

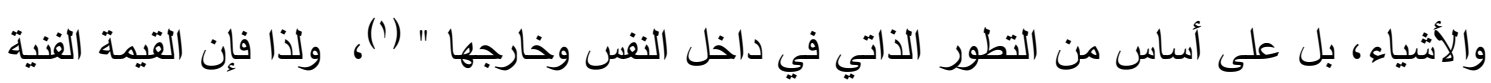

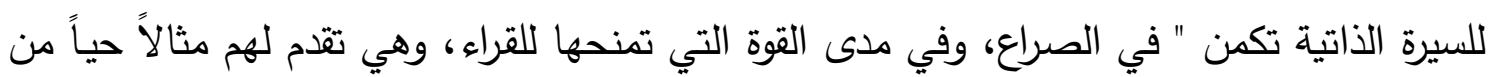

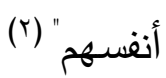
ويذهب بعض النقاد إلى: " أن حظ الترجمة الذاتية من البقاء، يرجع في الغالب، إلى مدى ما

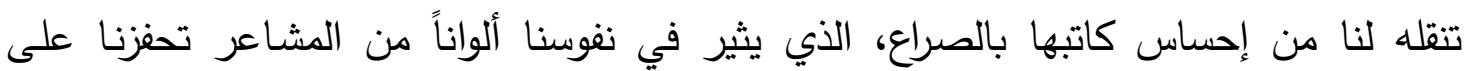

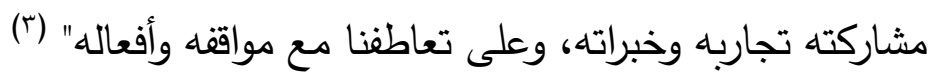

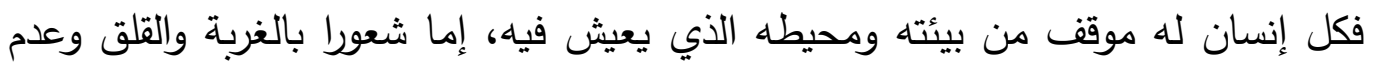

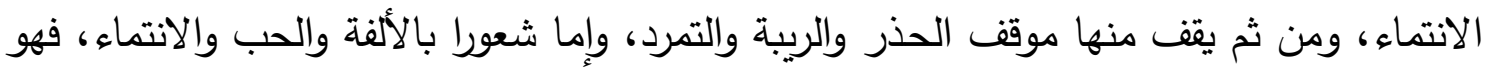
دائم الحنين والوصال والتذكر، وهذه المشاعر المتضاربة والمواقف المتباينة، هي نتيجة طبيعية

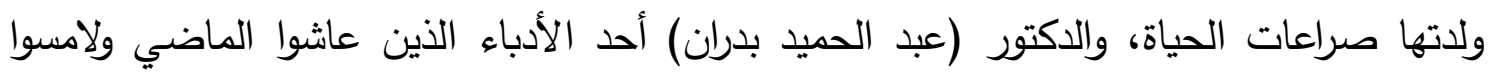
رحمته وقسوته، لكنه دائم الحنين والاسترجاع لله، وتصوير ما تعرّض له اعله في فترات حياته المتعاقبة.

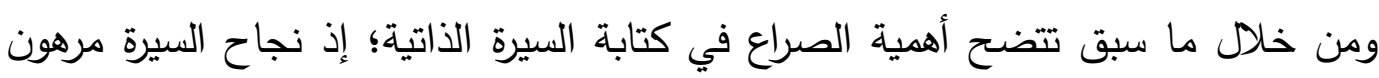

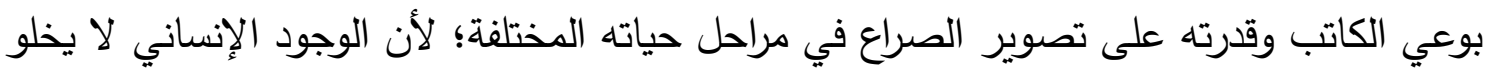

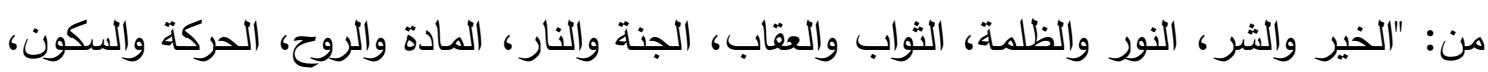

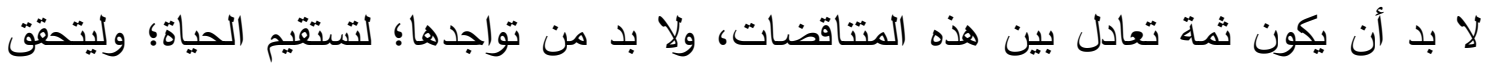

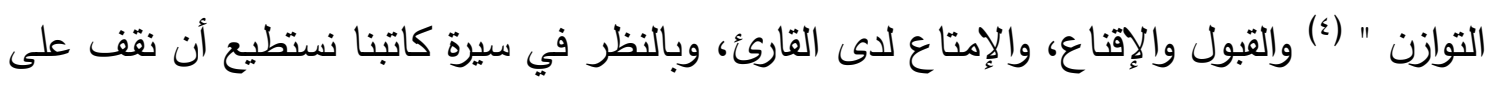
الكثير من صور الصراع، من ذلك:

\footnotetext{
(1) فن السيرة فن السيرة، دكتور إحسان عباس، ص999، دار صادر - بيروت - طا، 999 (م. (Y)

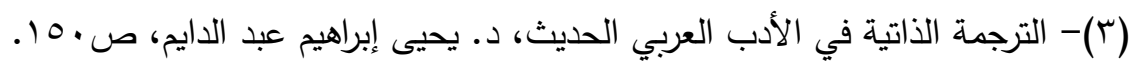

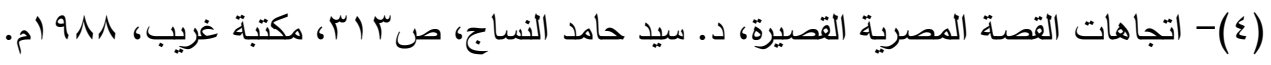




\section{أولا: الصراع المادي:}

فعلى الرغم من ضعف إمكانات كاتبنا وصراعه مع قساوة البيئة التي يعيش فيها، لكن ذلك الكادي

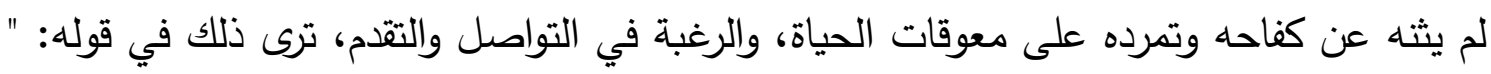

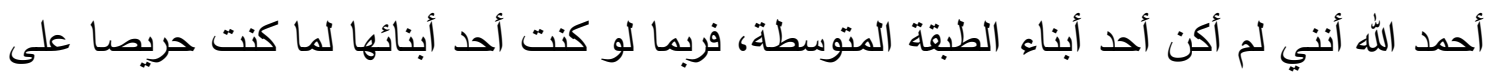

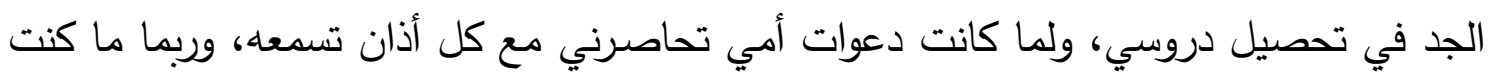

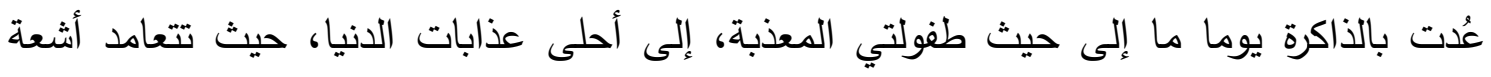

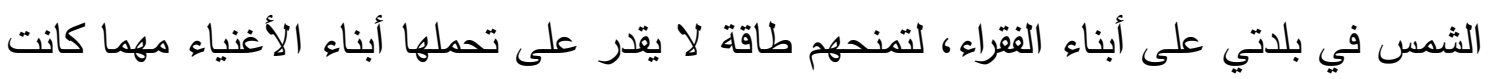

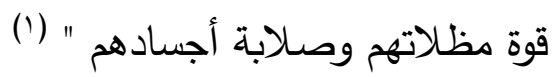
فالصراع -كما ترى- ناتج عن ضعف الإمكانات، الذي يعاني منه أغلب أبناء الريف،

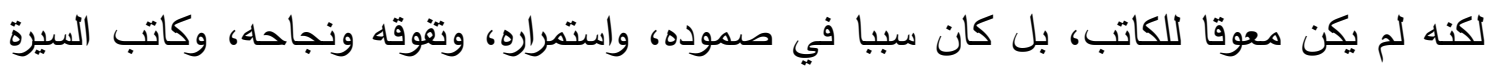

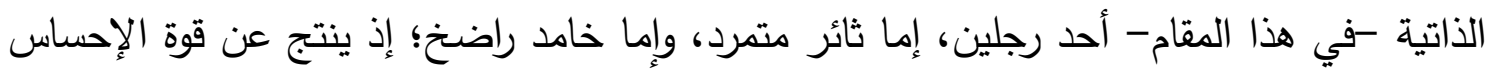
بالصراع في نفوس كتاب الترجمة الذاتية: " أن غلبت على ترجماتهم الذاتية روح الثورة والتمرد....

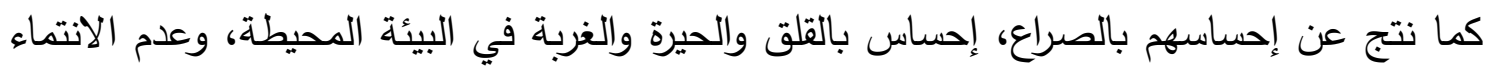

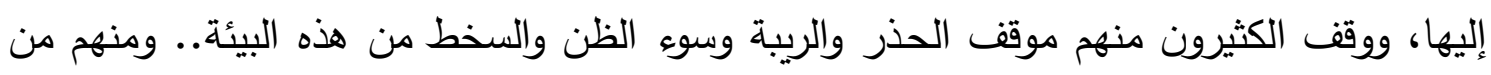

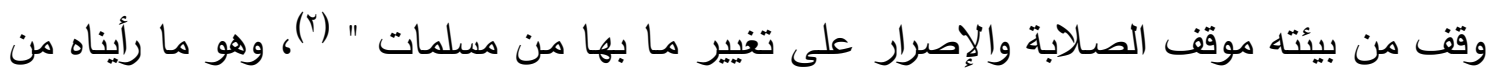
كاتبنا، حيث كان الصراع المادي مقدمة لتفوقه ونجاحه. ويظهر ذلك من خلال تساؤله حول تذكره الدائم لزملاء الدراسة " أم أنها محاولة للتباهي بما أنعاه أنعم الله

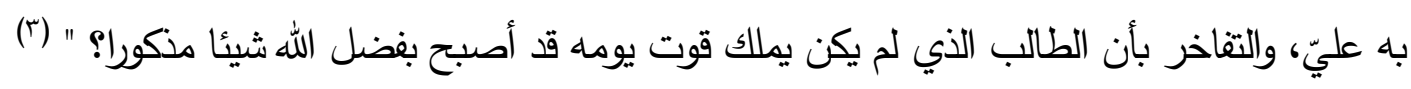

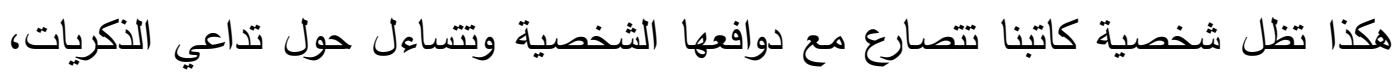

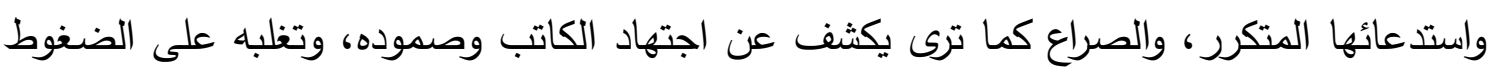

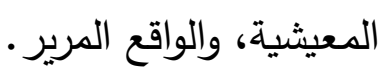

وفي هذا السياق أيضا يقول " لا أظن أنها تذكر الطفل ذا الكساء القطني المخطط الذي كان همه

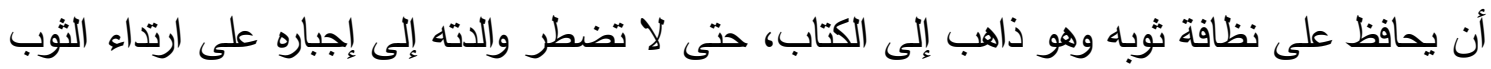

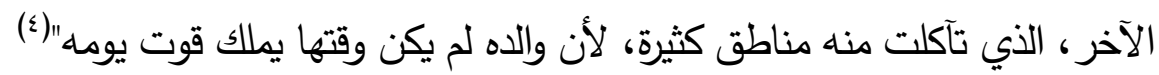

$$
\begin{aligned}
& \text { (1) - ابن الريف، ص } 0 .
\end{aligned}
$$

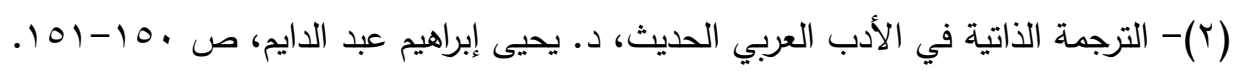

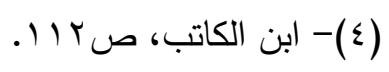




\section{تلداخل النوع الأببي بين السيرة الثاتية والرواية في أدب الدكتور عبد الحميد بلدان

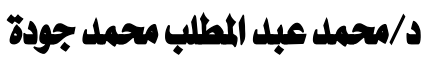

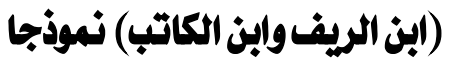

هذه اللفظة (قوت يومه) تكثف عن مدى المعاناة التي كان يعيشها كاتبنا، فهو يعيش بين

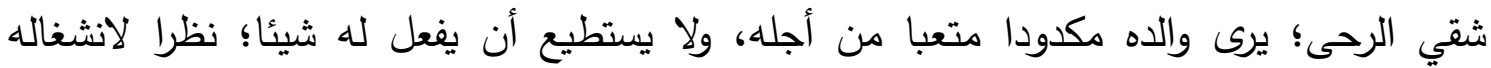

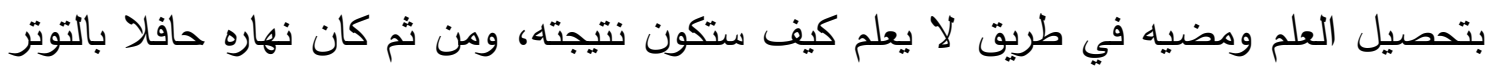
والقلق، وليله حافلا بالأحلام والكوابيس.

\section{ثانيا: الصراع النفسي واللاوعي:}

ويظهر هذا الصراع أيضا في سيرة كاتبنا بظهور فصل الثتاء، يقول: " لقد ظننتي لذلك

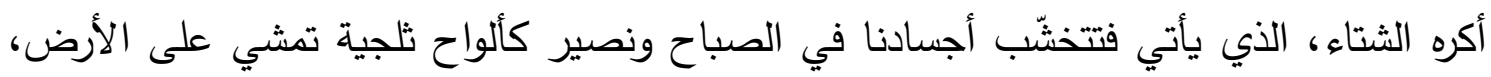
وتتدافع أنفاسنا الصغيرة مكونة سحابة من بخار الماء، الذي يتطاير كما يتطاير دخان المدخنين،

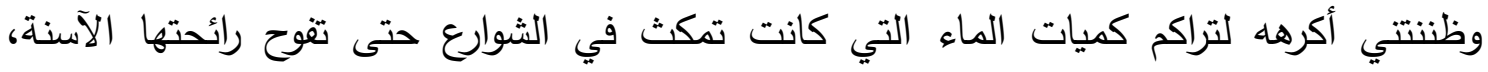

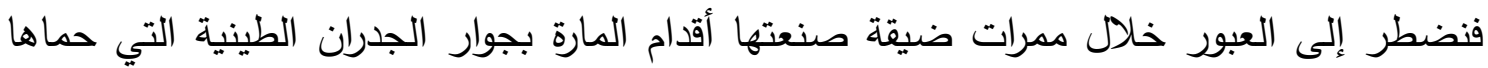

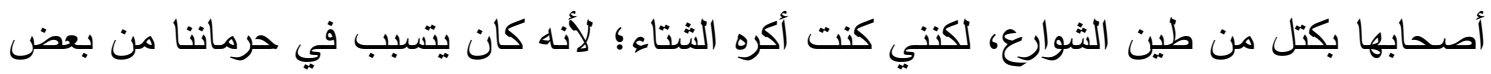
الدرسين الذين يفدون إلينا من المدينة.. كما كان يتسبب في حرماننا من بعض الطلاب الذين

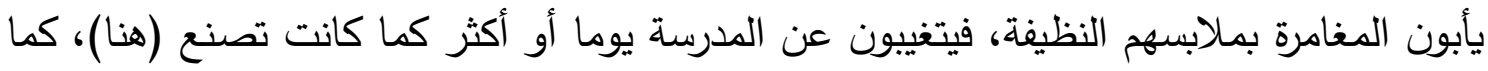

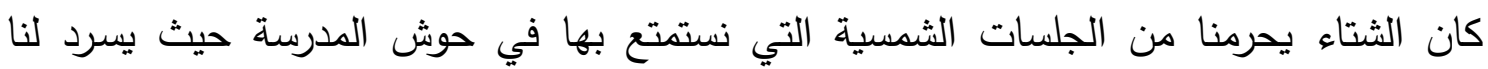

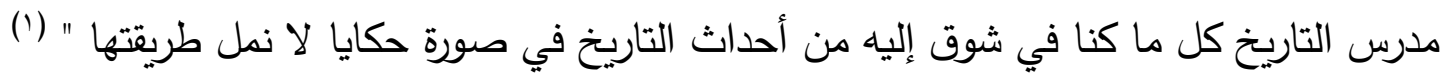

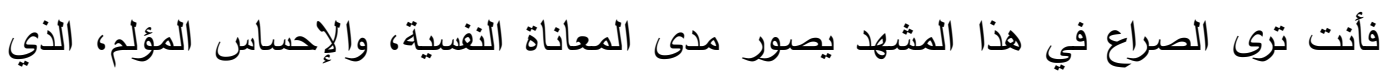

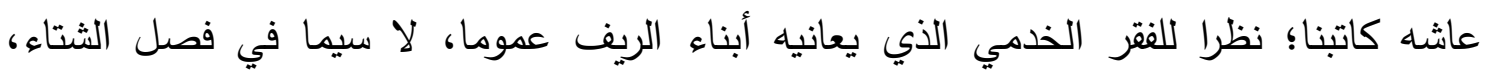
والصراع هنا يكثف عن قوة الإرادة التي يتحلى بها الكاتب، ومدى الحرص على التهله التعلم ومجالسة العلماء.

ويأتي الصراع الذي يكاد يقتل نفس الكاتب ويودي بحياته؛ نتيجة سطوة الخرافات

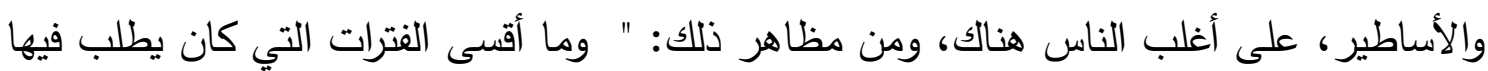

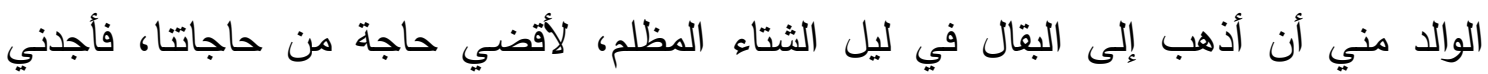

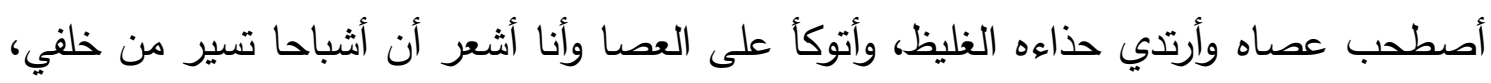

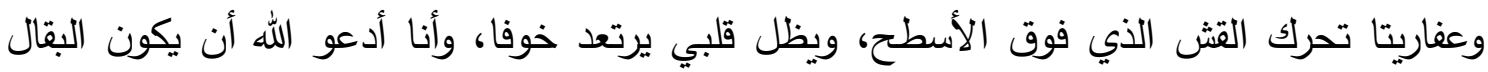

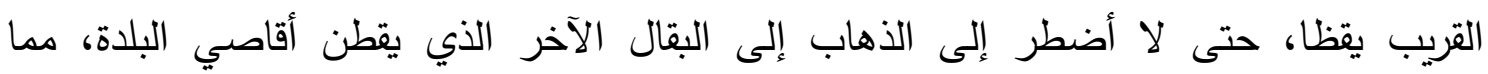


سيضطرني إلى المرور على المكان الذي قالوا بأن (زوج بثينة) قد قتل فيه، مما سيجعل شعري

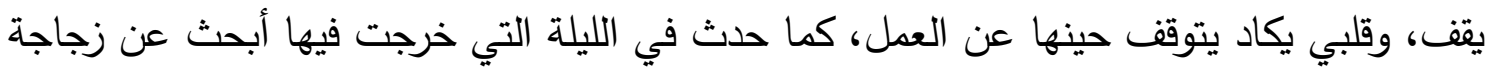

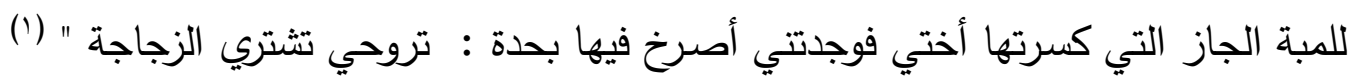

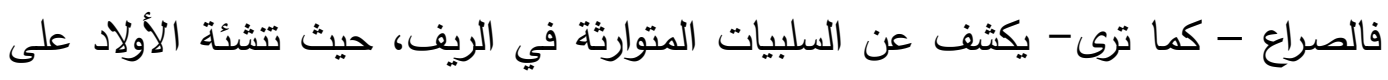

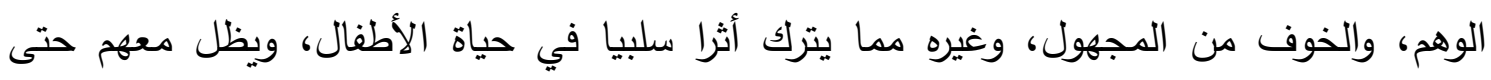
يصيروا رجالا؛ إذ لا يزال الكاتب يذكرها حتى الآن. ومن هذه الصور صراعه مع عالم الأحلام والكوابيس، وهي التجربة التي وقعت لأحد أولاده

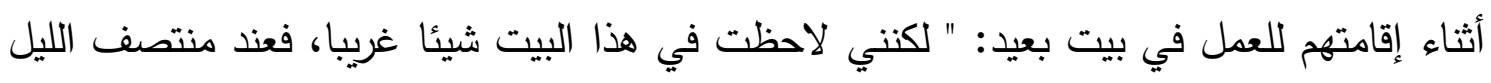

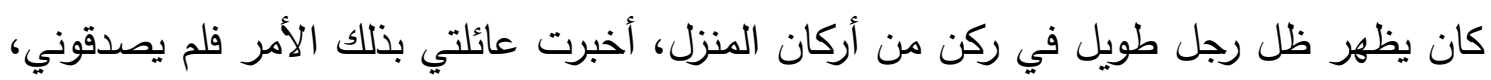

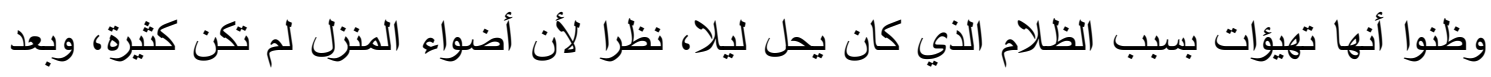

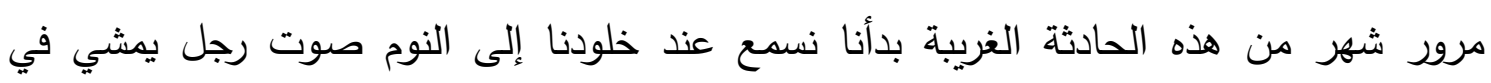
طرقات المنزل، حتى لم يكن أحد منا يجرؤ على الذهاب إلى دورة المياه.

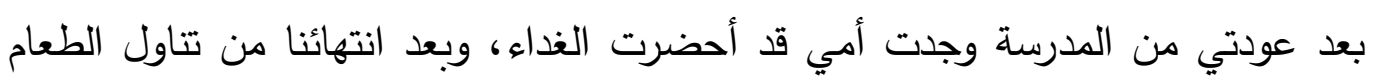

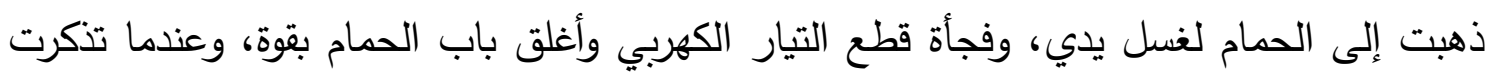

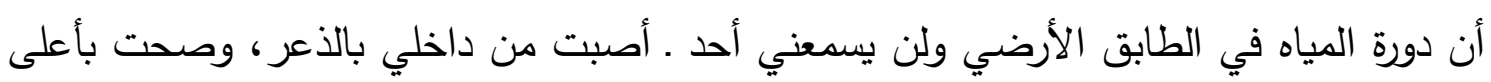

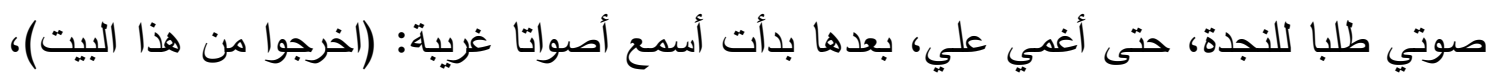

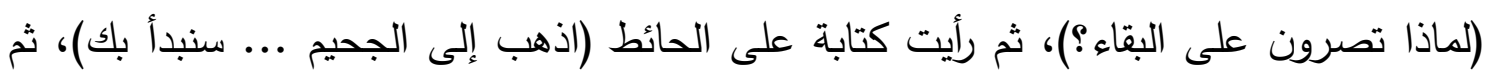

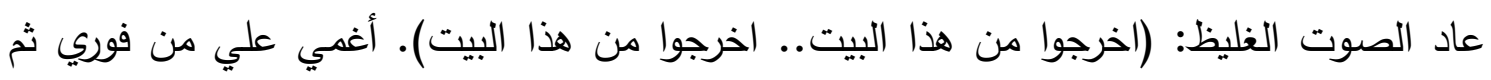

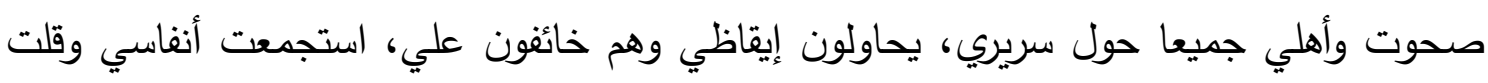

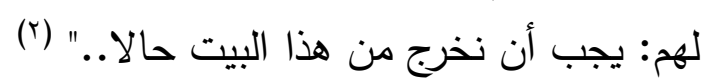
ومن هنا بدأ الاضطراب والقلق يسيطران على الكاتب وأسرته؛ حتى أصيب أحد أولاده

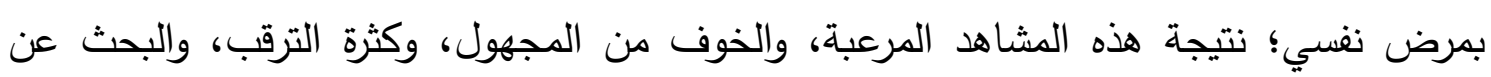

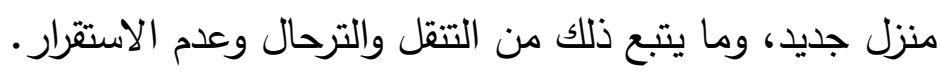

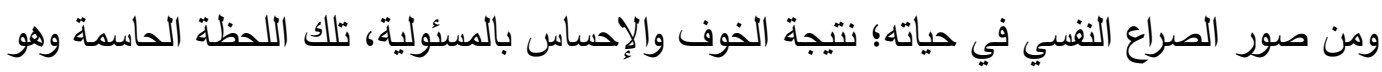

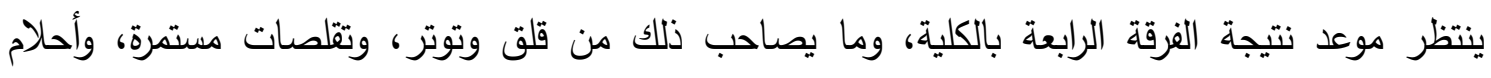

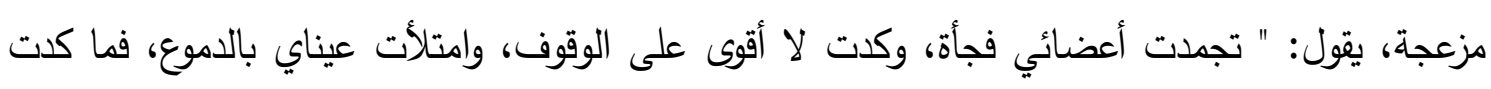

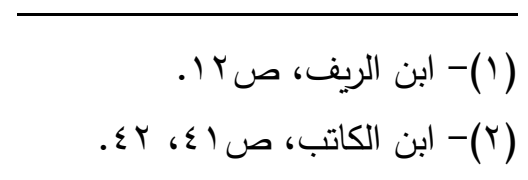




\section{تلداخل النوع الأببي بين السيرة الثاتية والرواية في أدب الدكتور عبد الحميد بلدان}

\section{د/محمد عبد المطلب محمل جودة

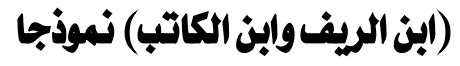

أبصر طريقي إلى منزلي، وسط حفر التليفونات الكثيرة التي تملأ الثوارع، وتناسيت مرة واحدة آلام المذاكرة

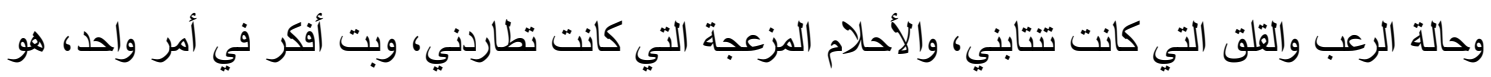

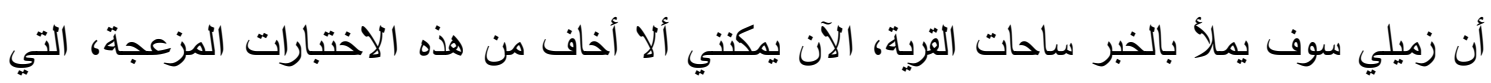

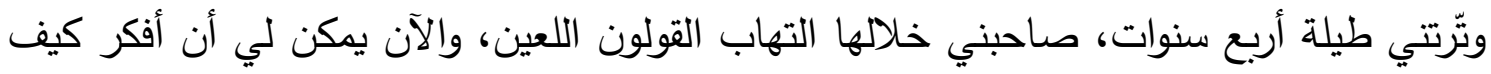

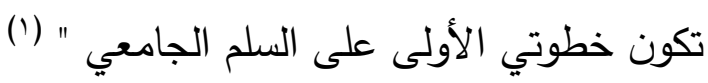
فالصراع هنا صراع تحديد المسار، وما يترتب عليه في المستقبل، والخوف من القادم والتفكير فيه بصفة مستمرة، بطريقة تكاد تتهك العقل والبدن؛ إذ هو صراع لازمه سنوات وليس صراع يوم وليلة.

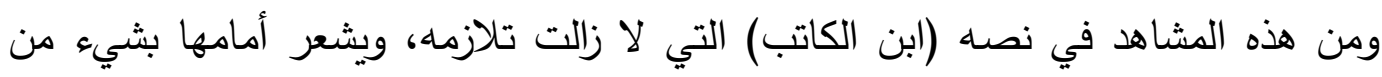

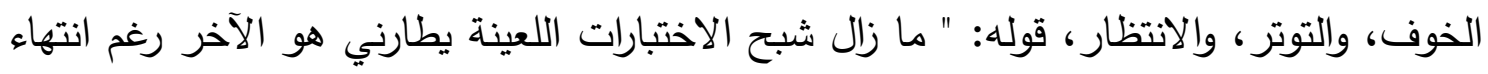

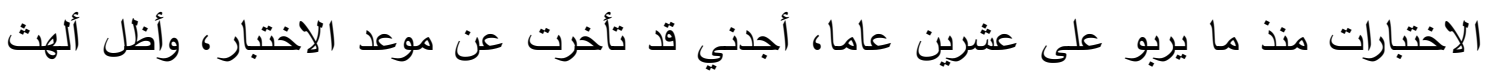

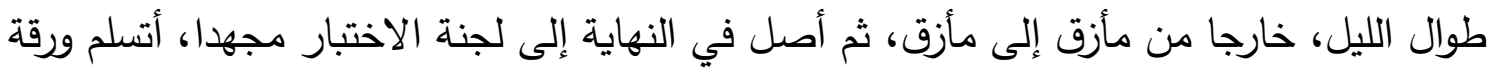

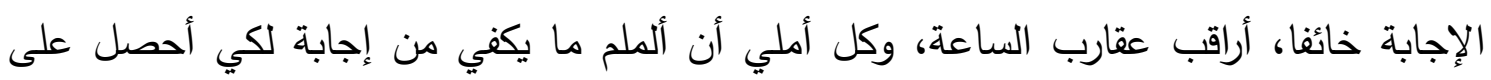

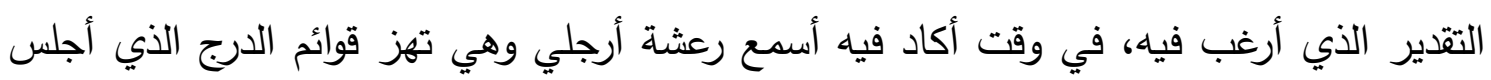
عليه.

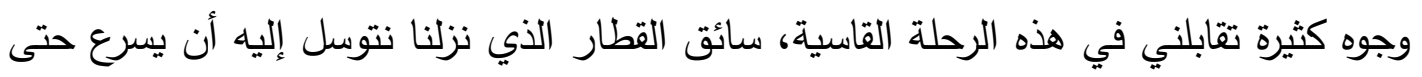

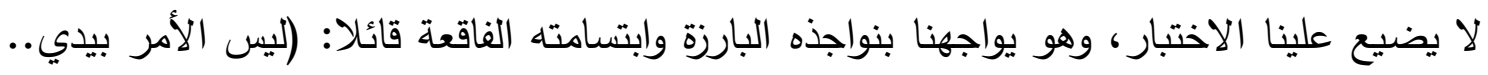

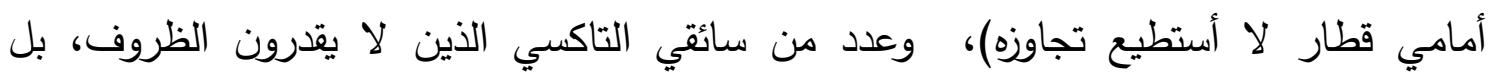

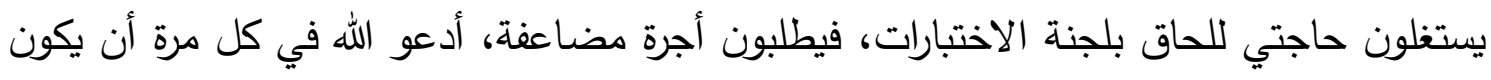

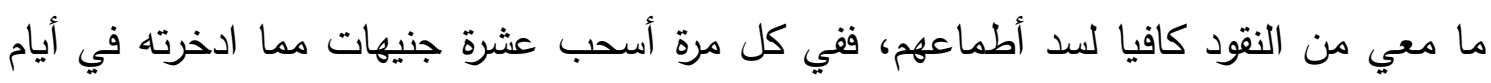

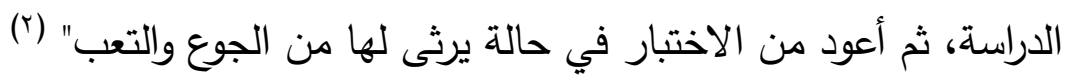

فالصراع -كما تلاحظ- يعكس حالة اللاوعي التي تتأجج قلقا، واضطرابا، وتوترا لدى الكاتب، كما تشعر فيها بلمسة إبداعه وهو يجعل القارئ في نفس حالة توتره وترقبه لما ستؤول إليه

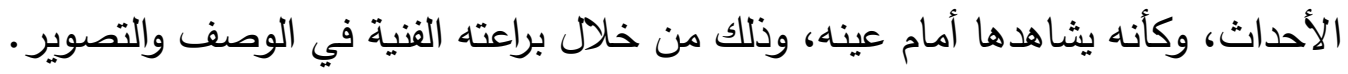


ثالثا: صراع العادات والتقاليد:

ويأخذ الصراع هنا مظهرا مغايرا، حيث صراع العادات والتقاليد في أمور الزواج والحب، والثاء

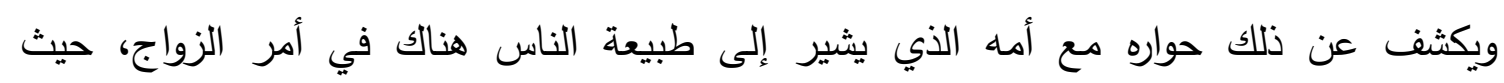

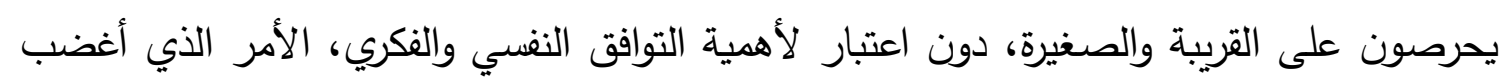

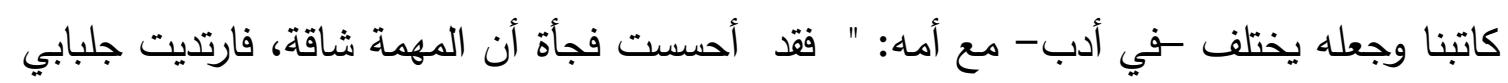

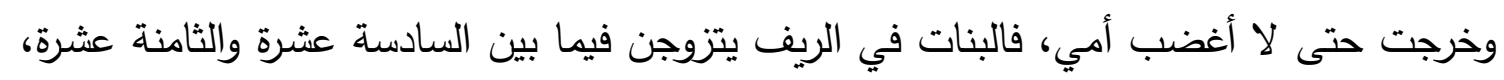

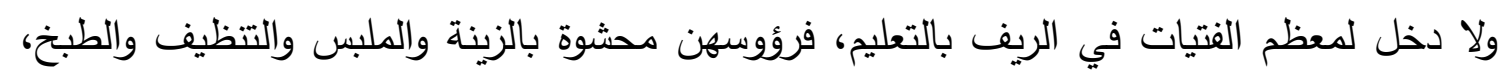

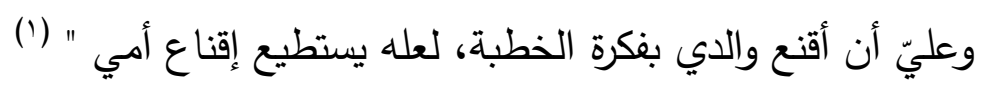

ومن ذلك أيضا تألمه لما أصاب زميله (يحيى)، الذي كاد يفقد روحه منتحرا؛ نظرا لعدم

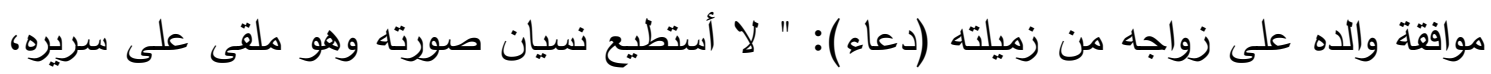

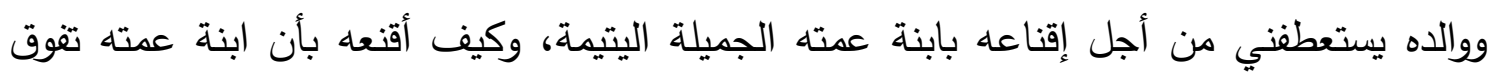

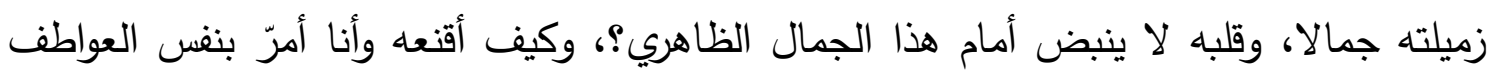

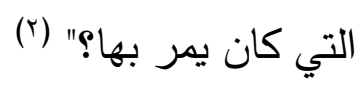
فالصراع - كما تلاحظ - في النصوص السابقة، يكثف عن طبيعة التركيبة الاجتماعية في

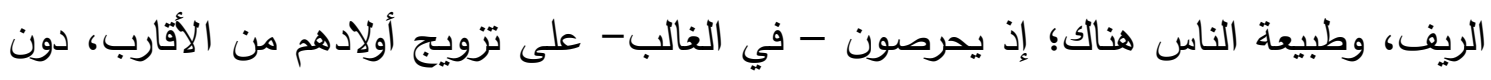

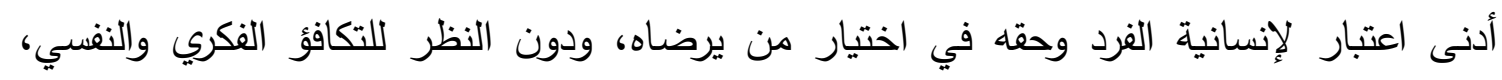

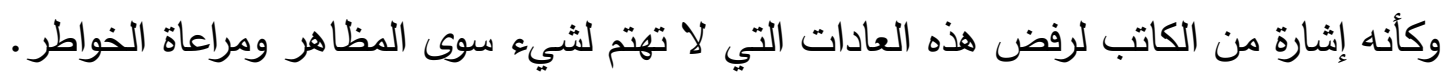

وينتج الصراع في حياة كاتبنا؛ نتيجة تسلط بعض كبار السن في المساجد، وهي صورة

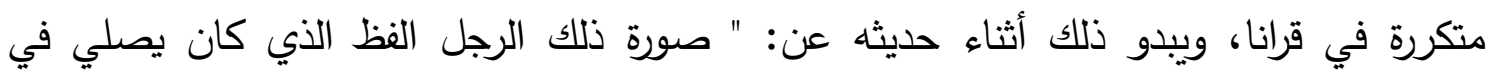
المسجد القريب من بيتنا، ويصر على تأخيري عن الصف الأول، حتى لو كان غير مكتمل، وكأنه

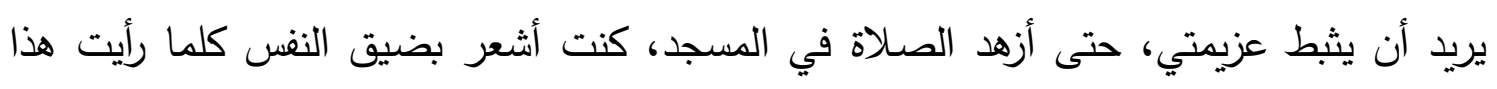

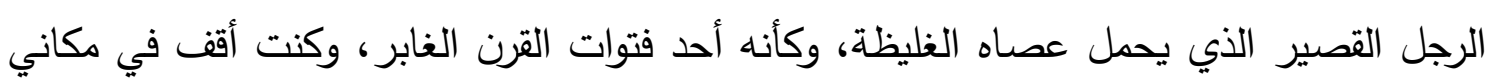

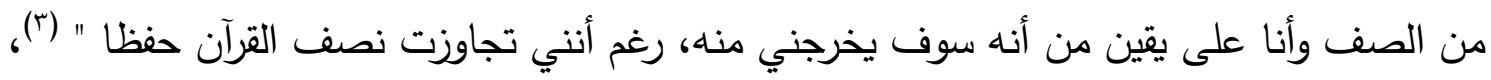

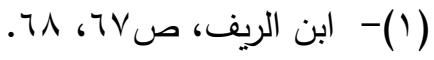

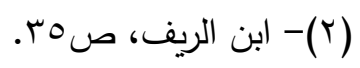

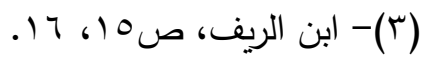




\section{تلداخل النوع الأببي بين السيرة الثاتية والرواية في أدب الدكتور عبد الحميد بلران \\ دمحمل عبد المطلب محعل جودة \\ (ابن الريفوابن الكاتب) نموذجا}

وهذه مشاهد تكثر في الريف -في الغالب- وتتكرر؛ بصورة استفزت الكاتب وآلمته، وتركت أثرا سلبيا في ذاكرته، وإثارته إليها إثارة رفض واستهجان؛ مخافة أن يغادر أطفالنا بيوت الله إلى بيوت أخرى.

وفي هذا السياق، يأتي الصراع في سيرة كاتبنا أيضا؛ نتيجة مؤثرات خارجية، كسلطة الأب البات

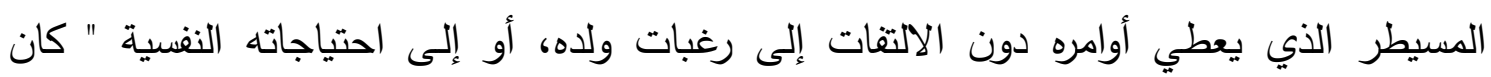

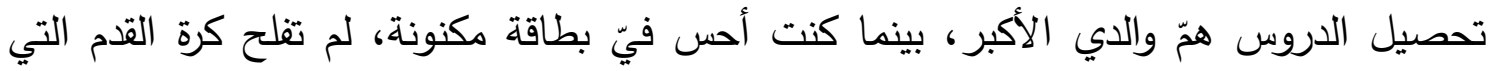

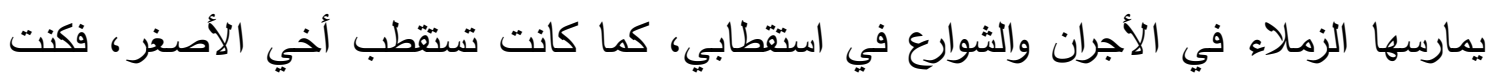

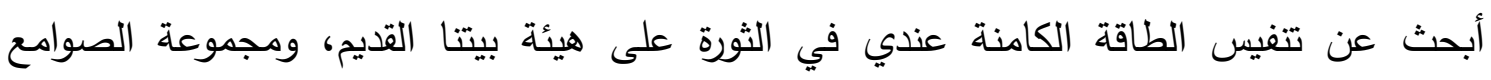

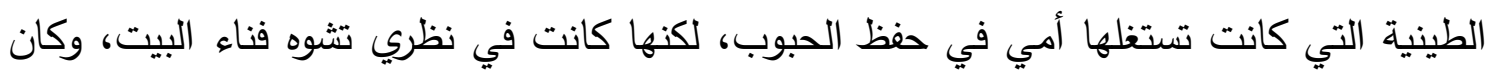

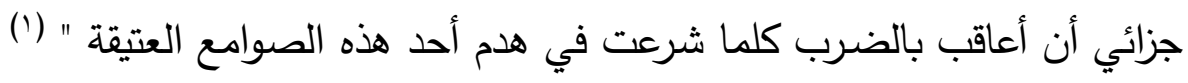


رابعا: صراع الفقد وإلغربة:

ويمثله تألمه لفقد أمه التي لا يزال يذكرها، يقول: " إن حدثتك يا بني عن الذكريات

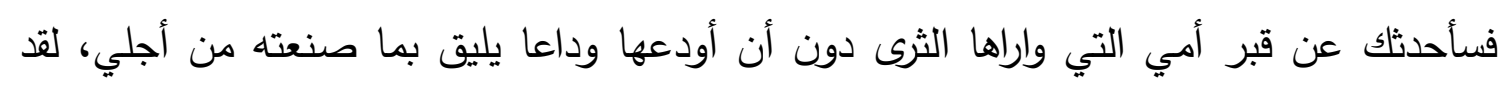

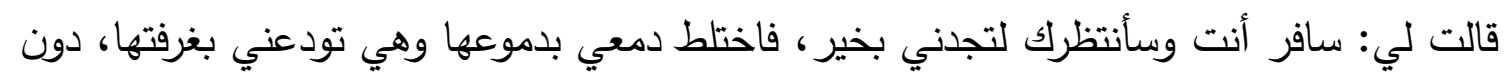

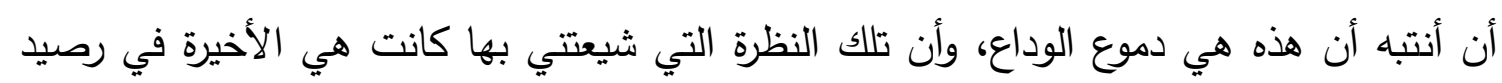

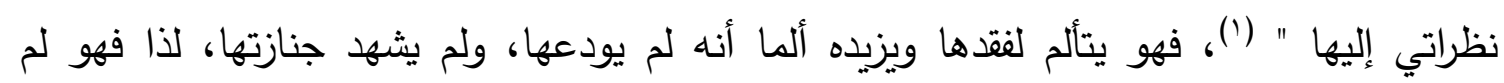
يصدق أنها فارقت الحياة.

وفي هذا السياق تألمه وصراعه النفسي لفقد زميلة الدراسة (هدي)؛ إذ لا يزال يذكرها: "

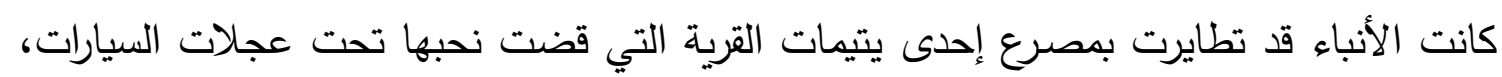

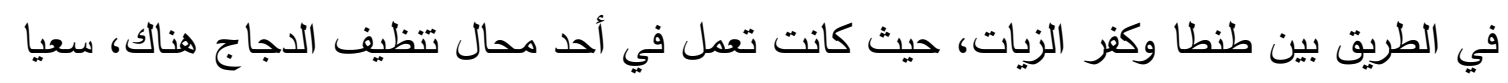

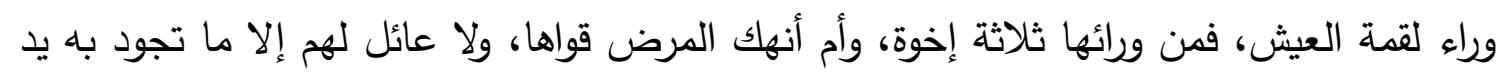

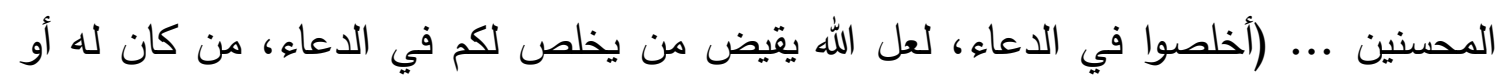

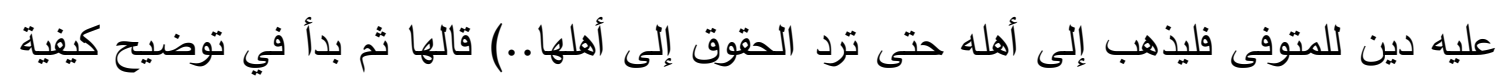

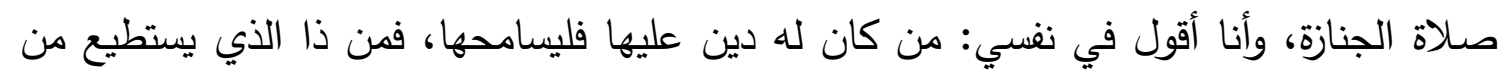

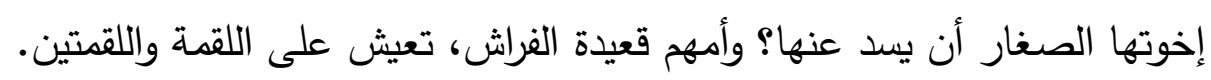

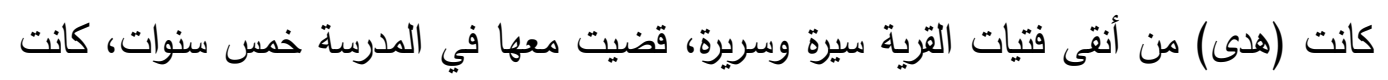

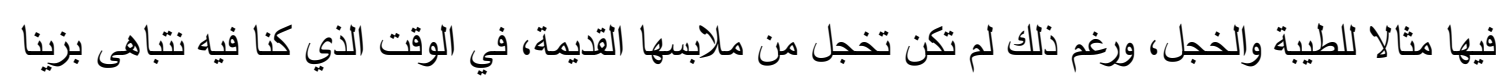

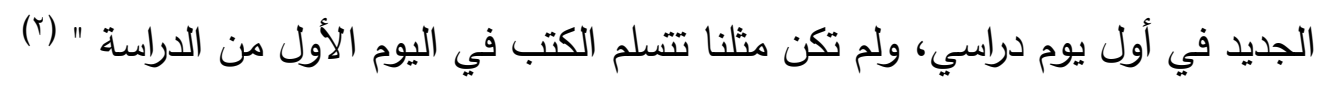

ويبدو صراع الغربة في قوله: " فكم كانت تقسو الرحلة كلما ذكرت الوطن، بأرضه

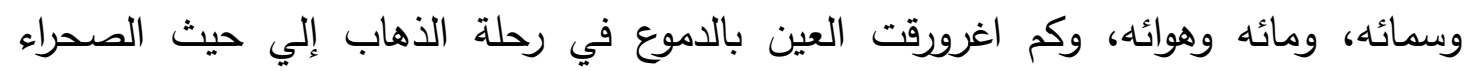

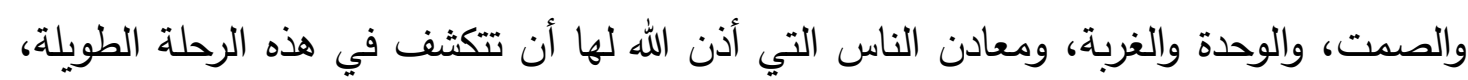

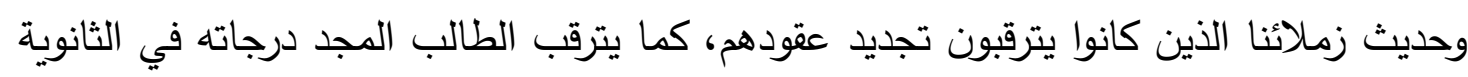

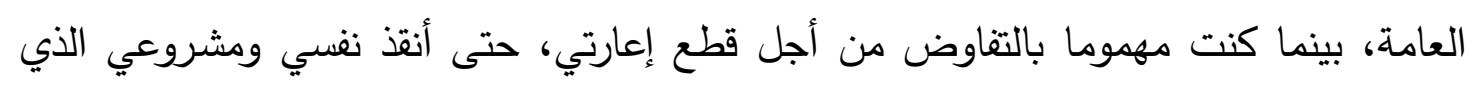

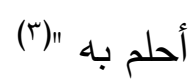

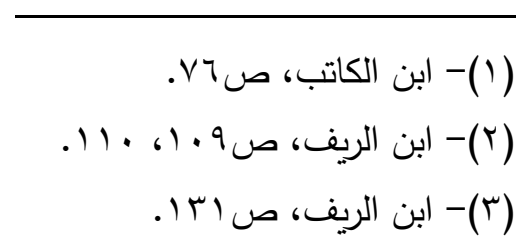




\section{تلاخل النوع الأببي بين السيرة الداتية والرواية في أدب الدكتور عبد الحميد بلدان}

\section{د/محمل عبد المطلب محمل جودة}

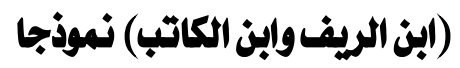

خامسا: صراع التجربة والإبداع:

ويبدو هذا الصراع بوضوح في نصه (ابن الكاتب) كما يوحي بذلك عنوانه؛ إذ يقدم فيه

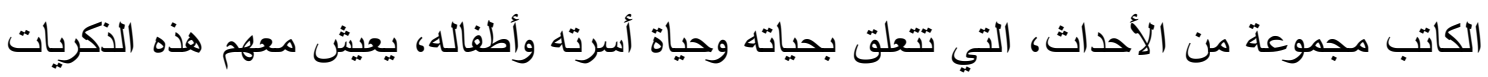

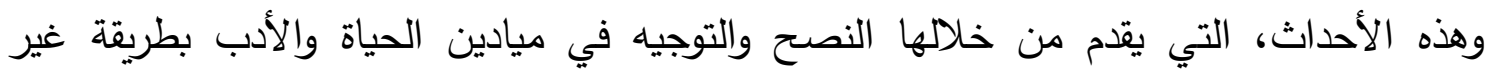

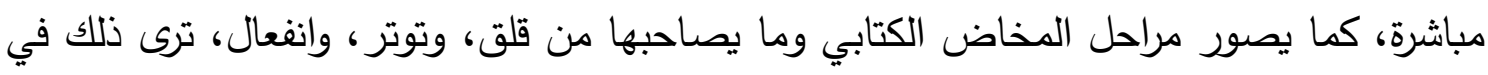

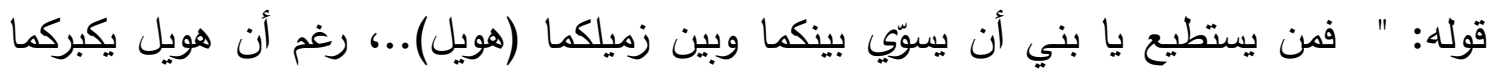

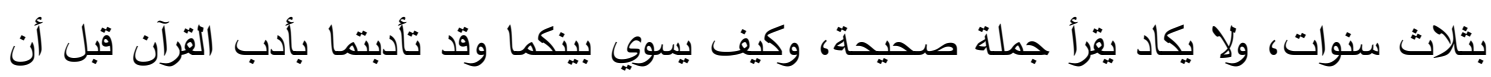

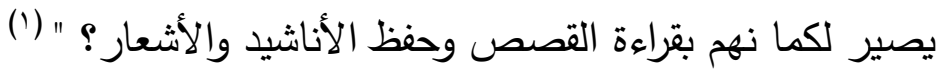

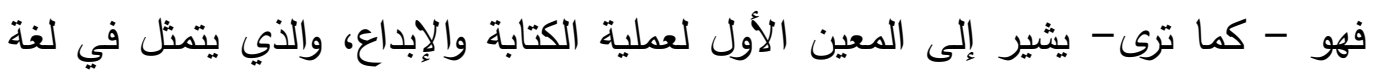

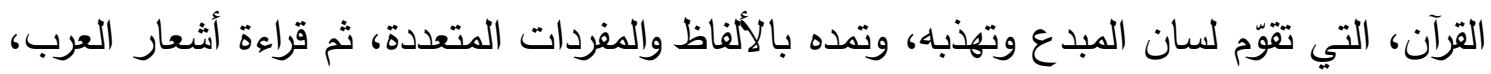
والقصص التي تتمي خيال المبدع وتزكيه.

وتراه يقول: " إنني أنظر إلى بيانك الخصب يا بني فأرى أنه قد توفر لله من الجودة

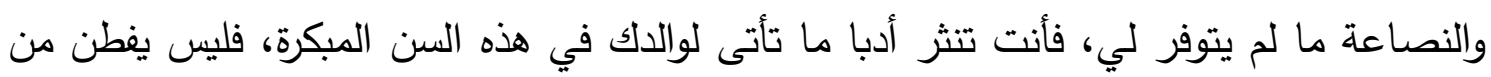

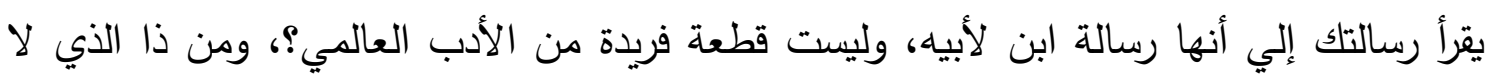

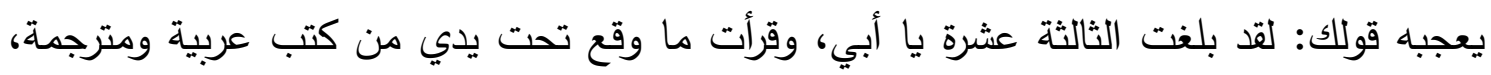
وأعجبت بكثير من الكتابات التي حاكيت بعضها دون أن أشعر أنها يمكن أن تمثلني تمثيلا

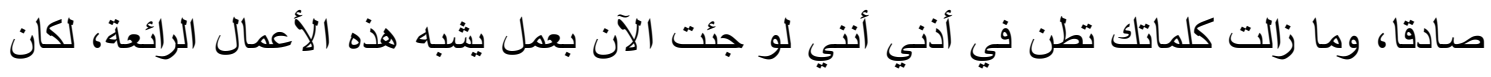

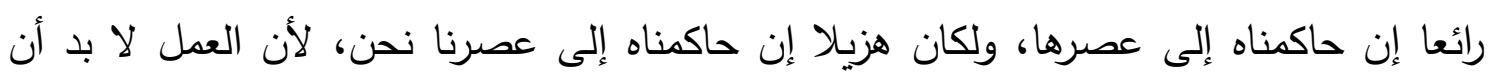

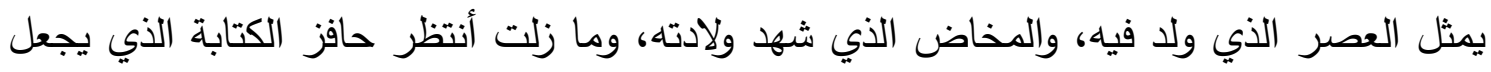

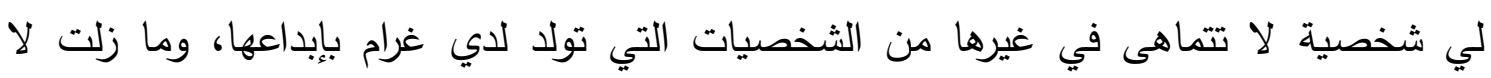
أستطيع التنقل بين الأفكار كما تتنقل أنت في رشاقة ولطف، حتى لو لو تباعدت الأفكار وتعددت

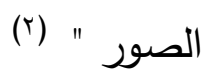

ولا زال يصور مظاهر القلق الفني وتجاربه المتفاعلة داخل نفسه؛ إذ يرى أن: " الأدب

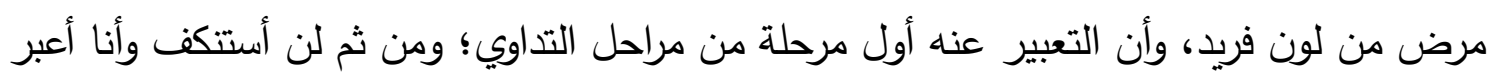

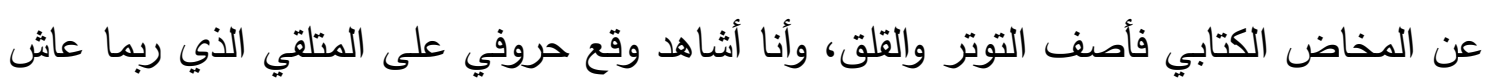

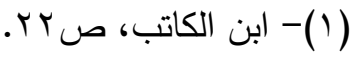

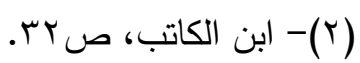




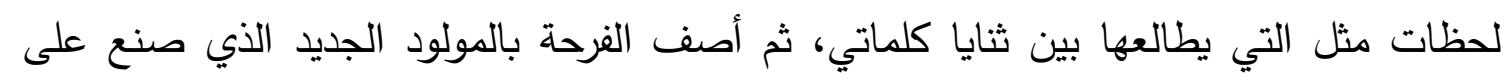

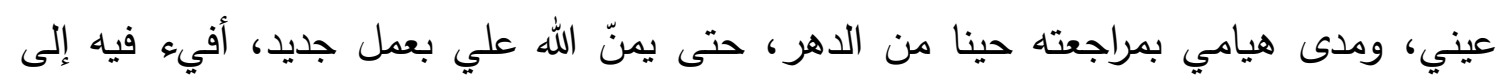

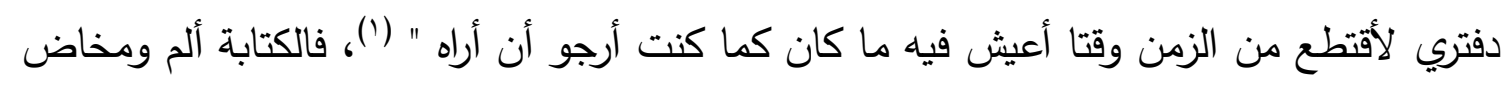

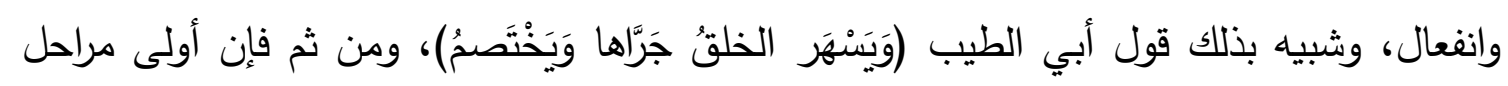

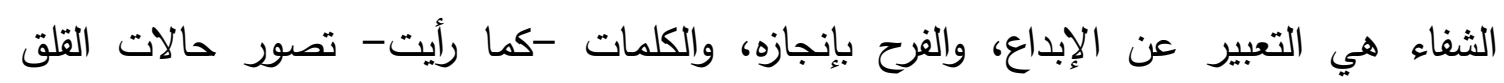

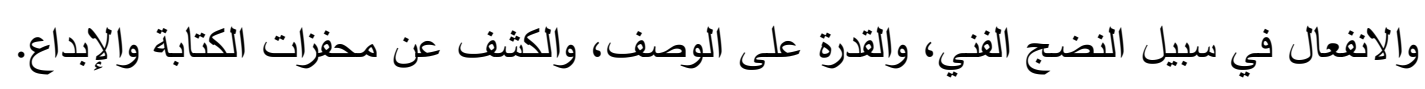

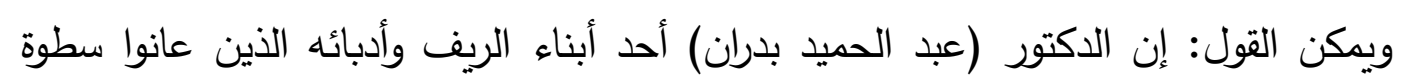

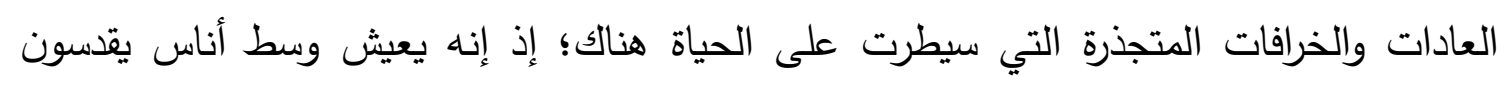

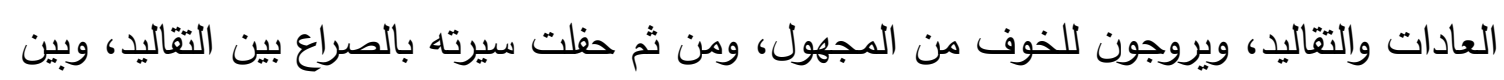

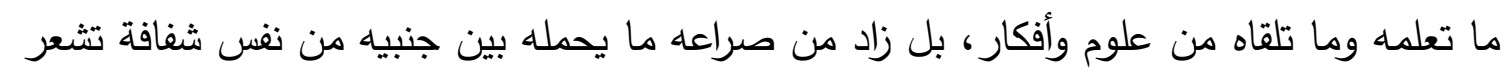

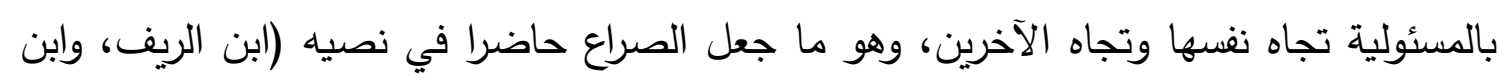
الكاتب) فابتعد إلى حد بعيد عن الكتابة العشوائية، والذكريات المتقطعة. 


\section{تلاخل النوع الأدبي بين السيرة الداتية والرواية في أدب الدكتور عبد الحميد بلدان \\ د/معل عبد المطلب محمل جودة

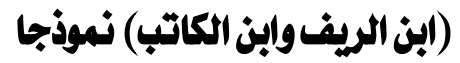

الصدق والصراحة

يختلف كاتب السيرة الذاتية عن كاتب السيرة الغيرية، فالأول يغوص داخل نفسه، ويقف منها

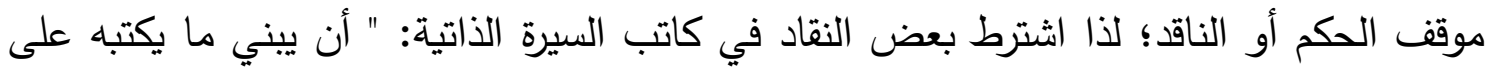
أساس متين من الصدق التاريخي، فإذا ضعف عنصر الصدق في السيرة لم تعد تسمى سيرة، لأن

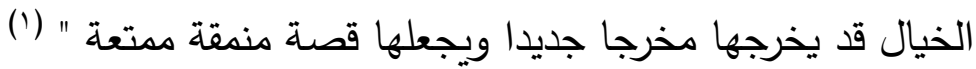

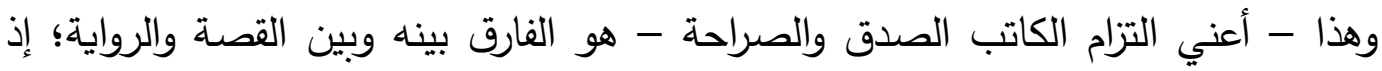

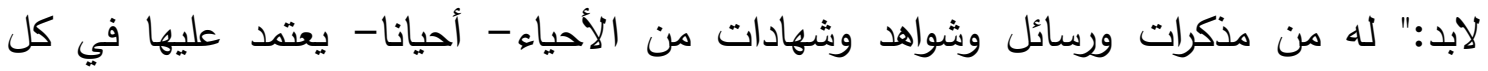

خطوة" (r)

لكن السؤال إلى أي مدى يمكن أن يلتزم كاتب السيرة الذاتية بالصدق والصراحة؟ و"

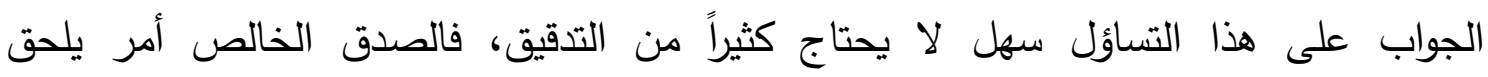
بالمستحيل، والحقيقة الذاتية صدق نسبي، مهما يخلص صاحبها في نقلها على حالها؛ ولذلك كان التئل

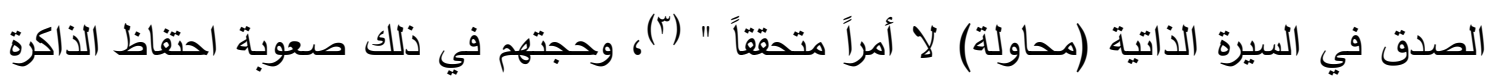
بجميع الأحداث، فهناك النسيان الطبيعي، والنسيان المتعد للأشياء التي يستحي الإنسان من فئن

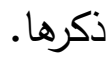

ف" الصدق المصض في الترجمة الذاتية - رغم أنها أصدق الفنون الأدبية تصويراً للإنسان هو مجرد محاولة، وهو صدق نسبي... لأن هنالك عوائق تعترض سبيل المترجم لنفسه، وتحول

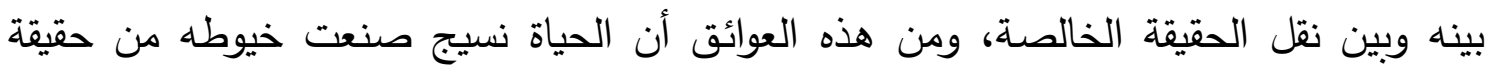

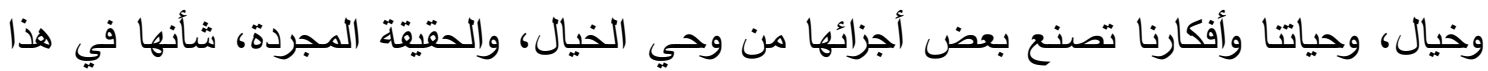

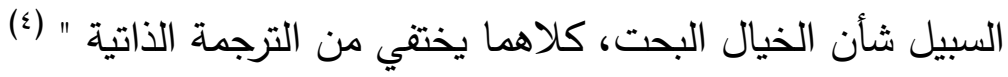
ولصاحب السيرة التي نحن بصدد دراستها، رأي في قضية (الصدق)، فهو يرى أن الصدئه

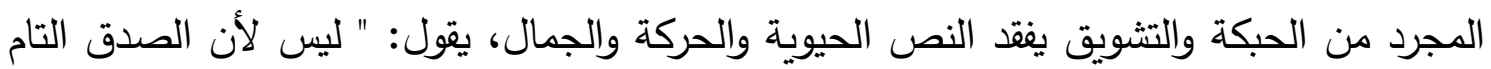

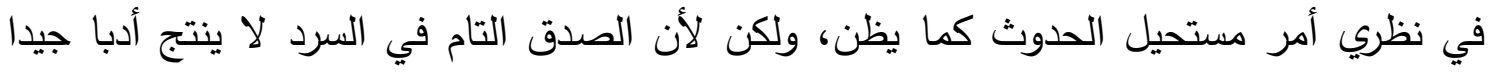

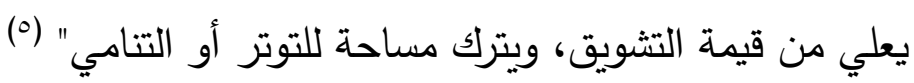

$$
\begin{aligned}
& \text { (1)- فن السيرة، إحسان عباس، صع V. } \\
& \text { (Y) }
\end{aligned}
$$

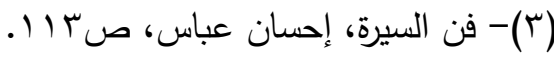

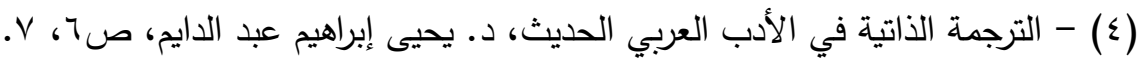

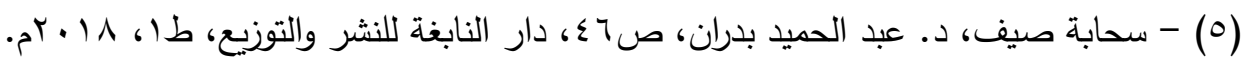


فهو يرى أن المزج بين الحقيقة والخيال يمنح الكاتب مساحة يتحرك فيها كيف شاء، كما أنه

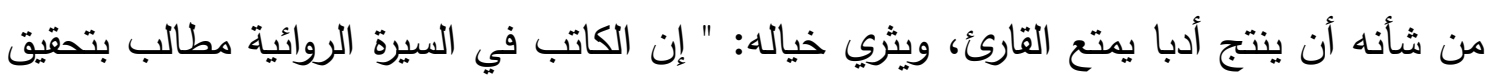

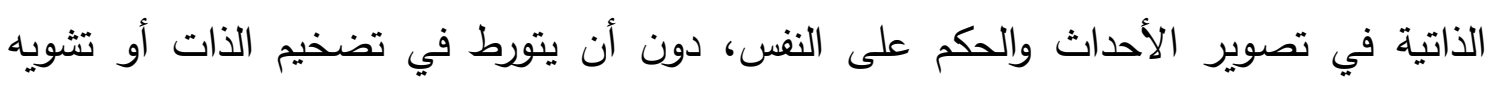

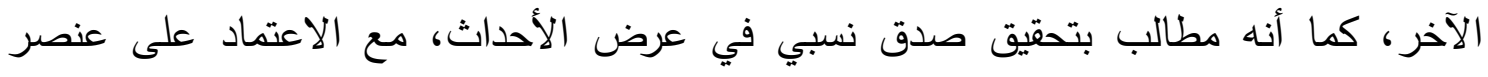

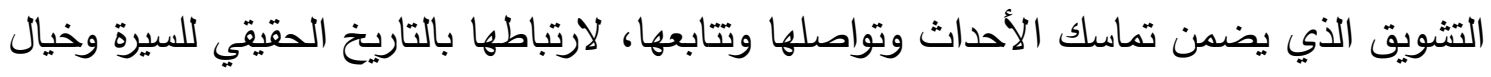
الكاتب" (")، فهو يرى أن الخيال المعتدل لا يتعارض مع الصدق في السيك السيرة الذاتية.

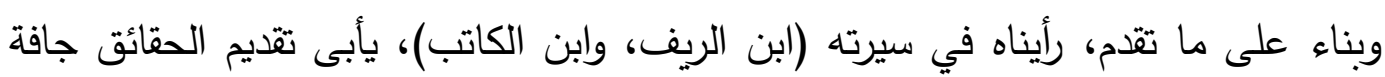

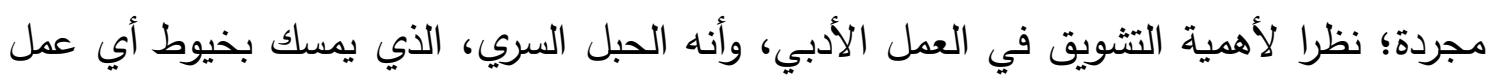

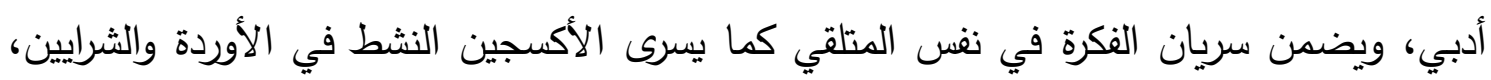

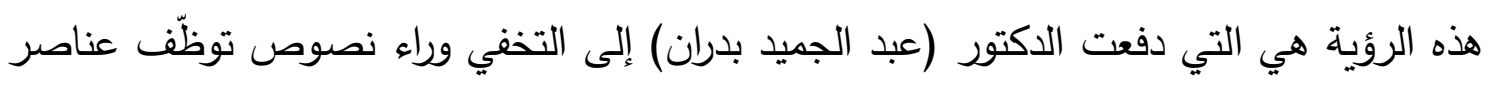

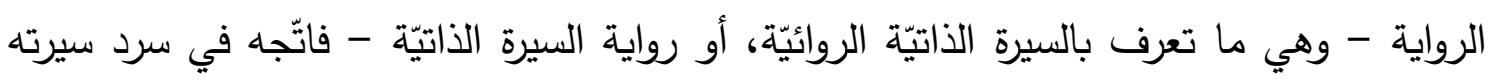

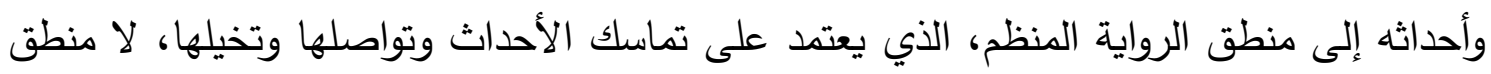

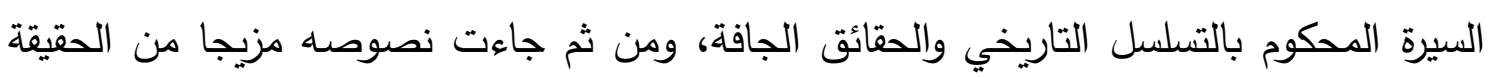
والخيال. وعلى الرغم من ذلك، فإن المشاهد التي جمّدت الصدق والصراحة في سيرة الكاتب كثيرة،

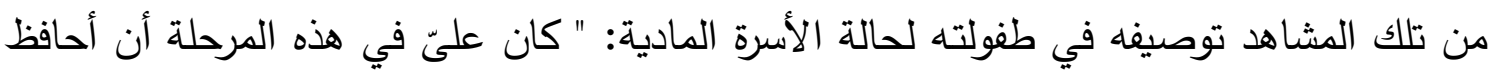

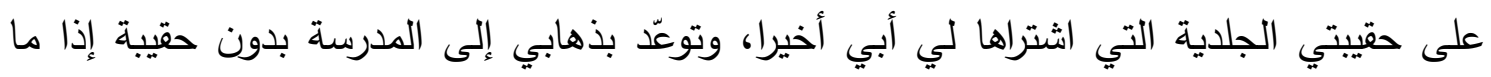

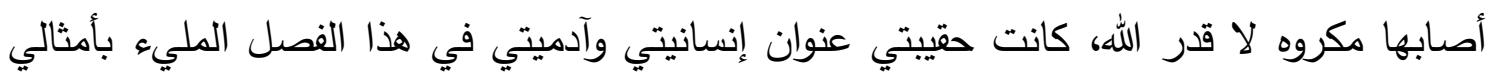
من غير ميسوري الحال وكان الحفاظ عليها عقيدة مثل المحافظة على الصلوات تماما بتمام، فأنّى إنى

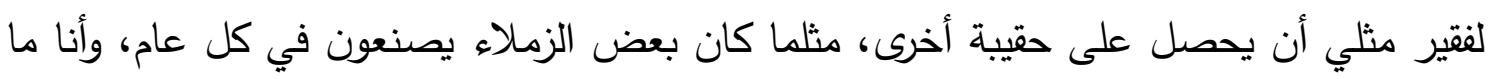

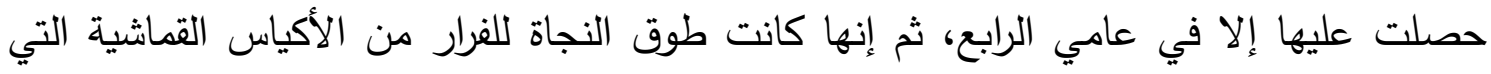

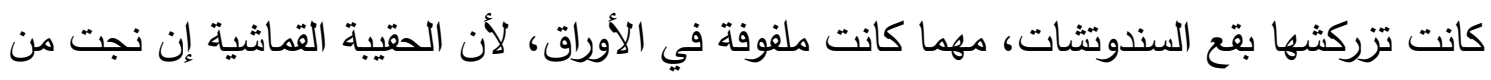

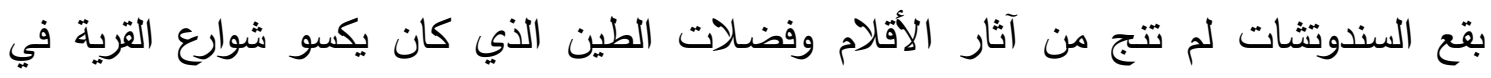

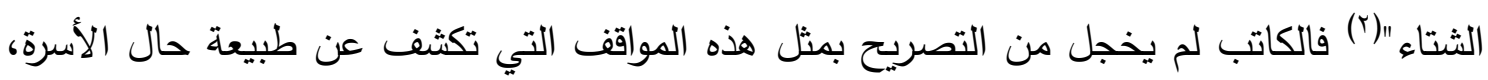

ومحدودية دخلها.

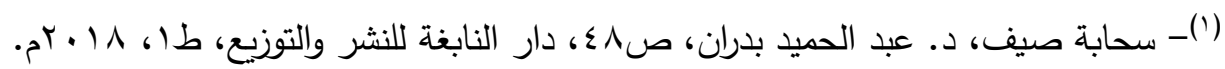

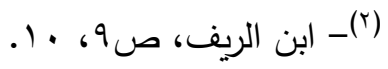




\section{تلداخل النوع الأببي بين السيرة الثاتية والرواية في أدب الدكتور عبد الحميد بلدان}

\section{د/محمد عبد المطلب محمل جودة \\ (ابن الريف وابن الكاتب) نعوذجا}

ويأتي في هذا السياق استرجاعه لأحاديث أحد أعمامه، و: " كيف كان يقضي ليله وهو يذاكر في ضوء مصباح الثارع، كي لا يضيء مصباح البيت وهو ينجز واجباته، فيضطر البيت

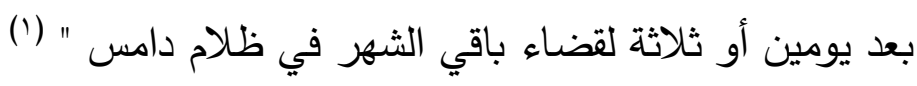

كذلك تسنطيع أن تدرك شفافية الكاتب، أثناء تصويره لبيت أسرته في السابق، وهو ماض

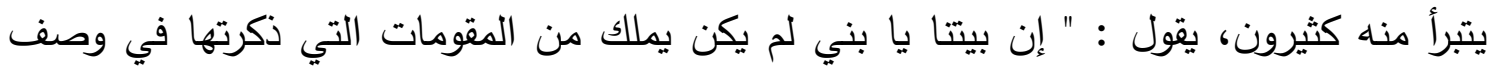

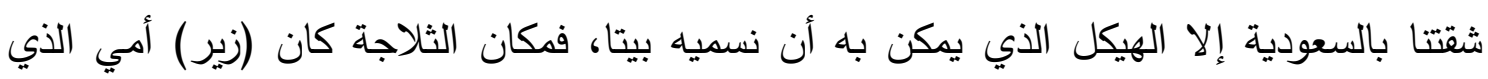

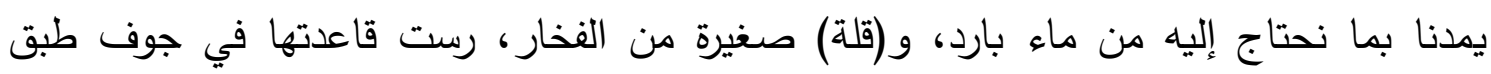

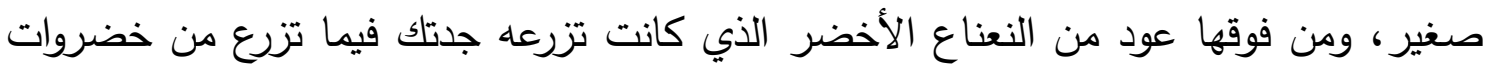

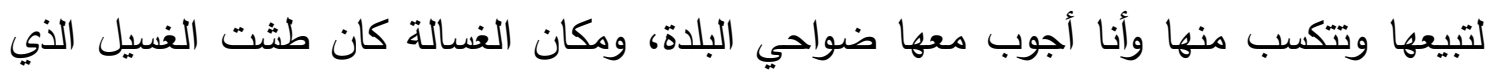

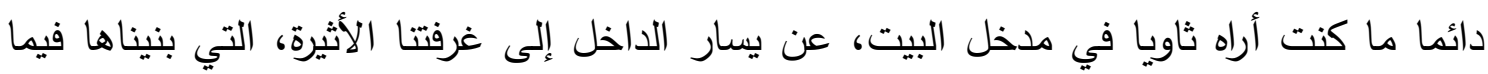

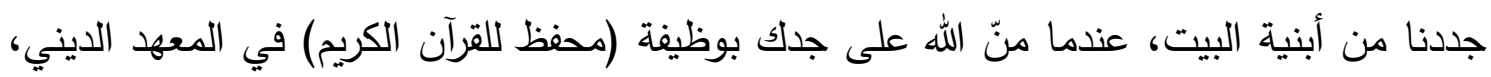

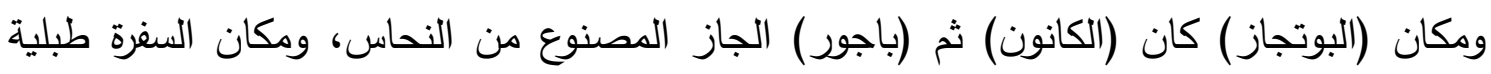

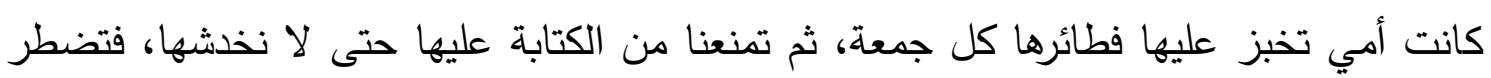

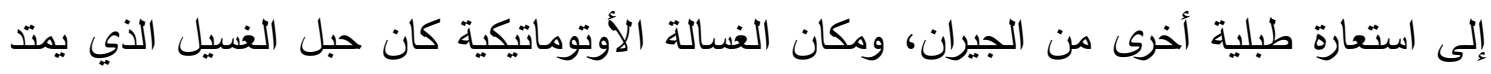

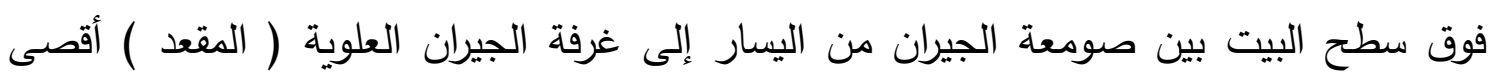

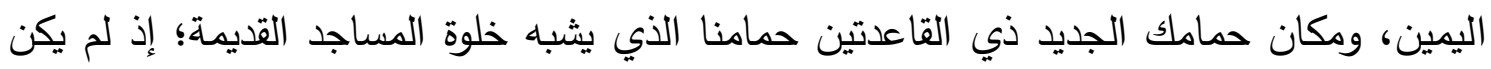

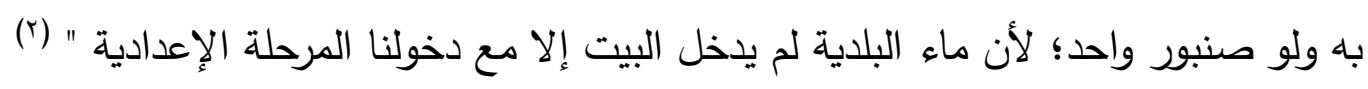

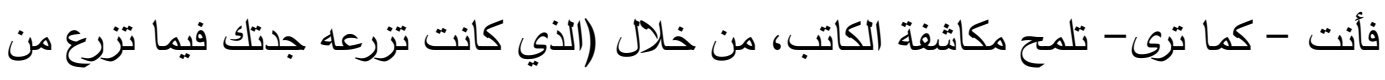

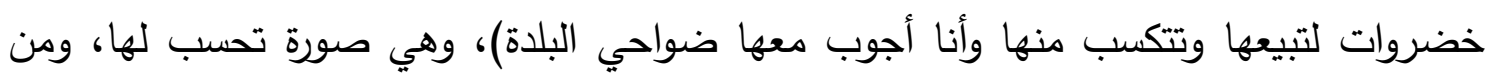

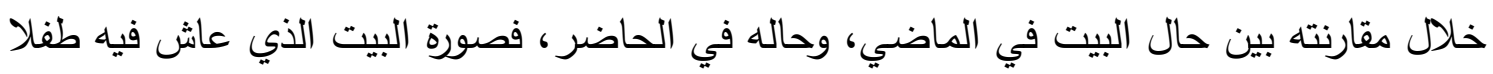

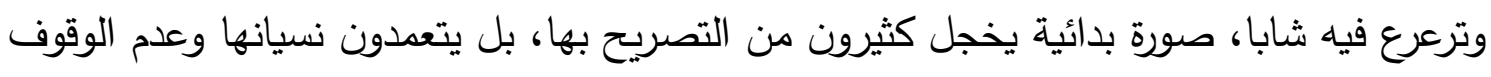

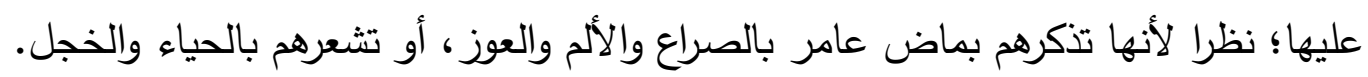

ويزيد هذه الصورة وضوحا، فيقول: " وكانت الدواجن تجوب البيت، فلا ينجو من مخلفاتها

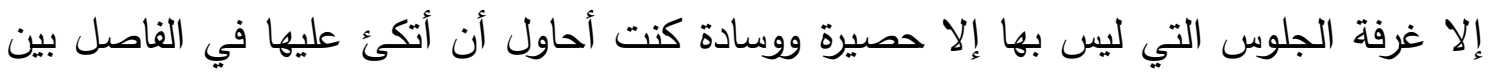
ساعات المذاكرة، فياتيني صوت البط المزعج، معلنا ثورته اليومية المشروعة في البحث عن طعام.

$$
\begin{aligned}
& \text { (')- ابن الريف، صاس" (1) }
\end{aligned}
$$

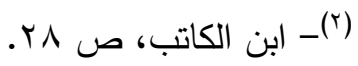


لقد عدّلنا من هيئة البيت كثيرا يا بني، فكانت أقفاص الحمام معلقة فوق باب غرفتي، ولم

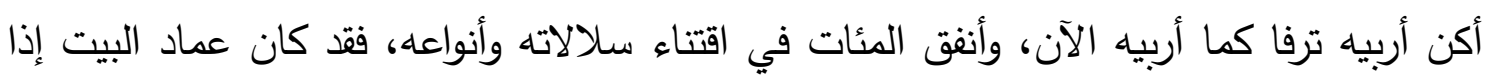

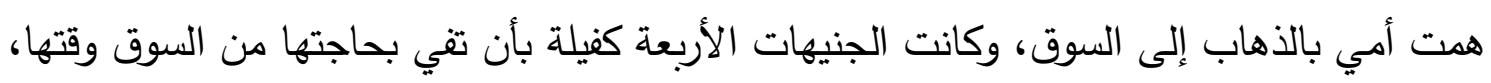

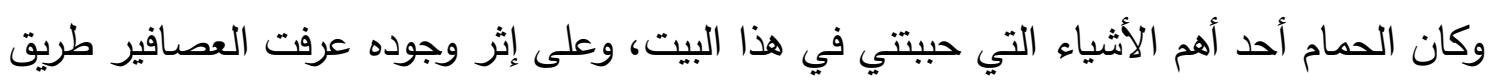

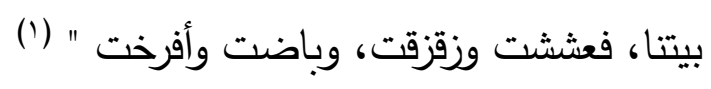

وتبدو صراحة الكاتب في تسجيله لسيرة حياته وانتقائه لمواققها، يقول: " ومرت كل اللحظات

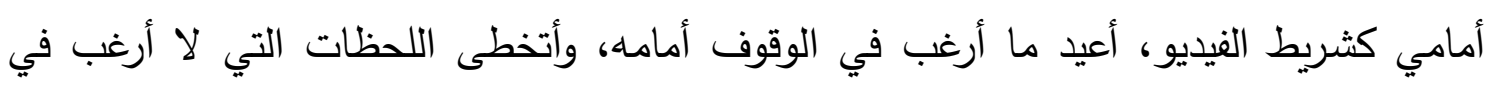

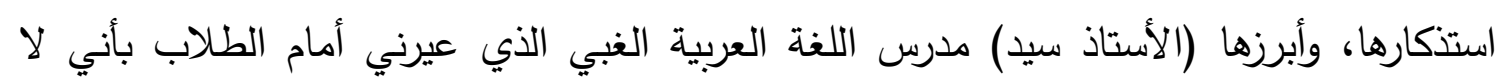

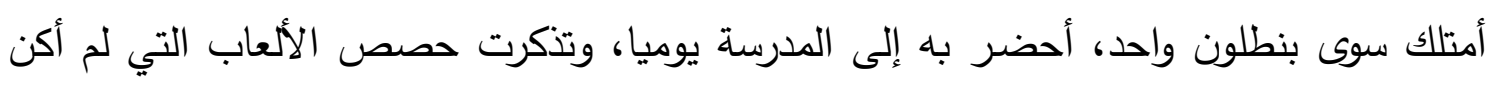

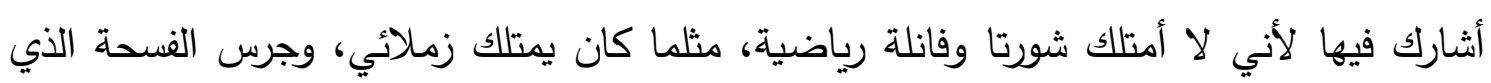

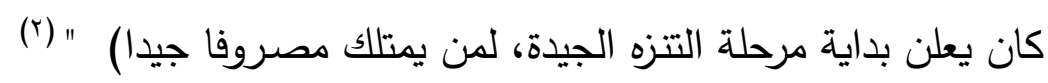
فعلى الرغم من تصريح الكاتب باستيائه من بعض المواقف، والرغبة العارمة في عدم

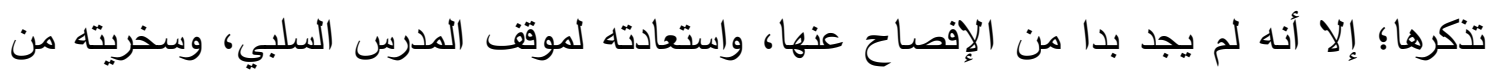

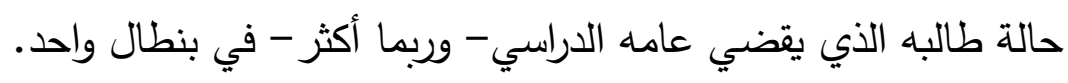

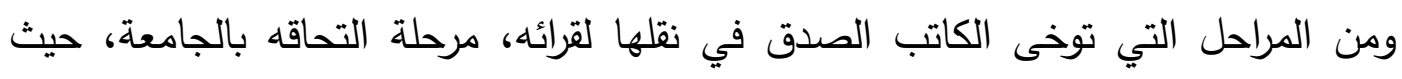

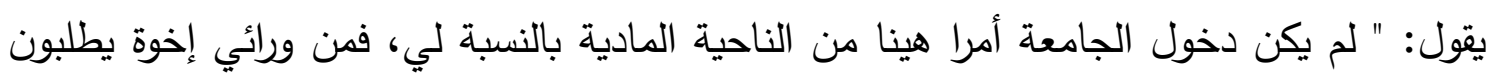

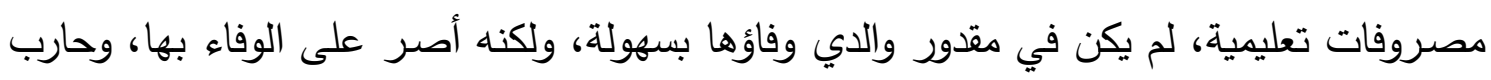

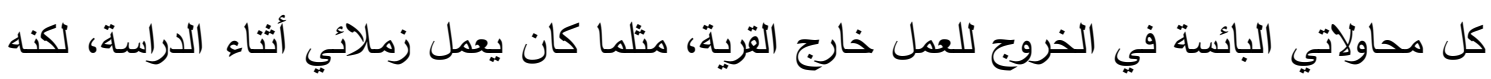

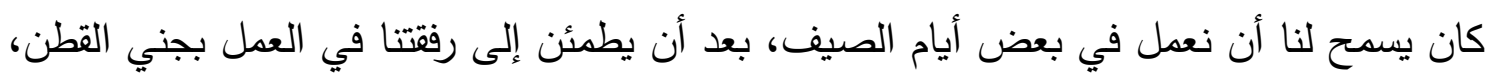

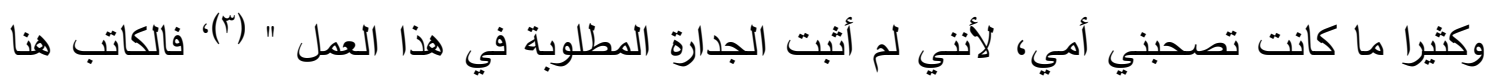

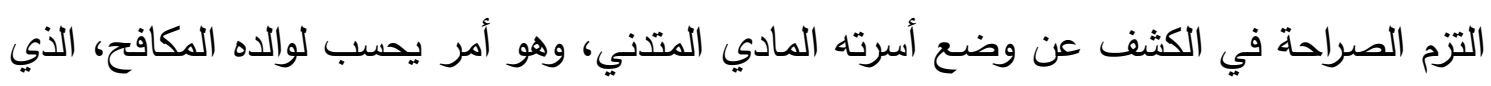
أصر على مواصلة تعليم أولاده، بالرغم من تردي حالته المادية.

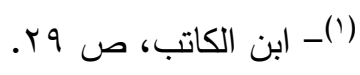

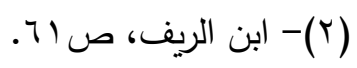

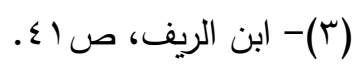




\section{تداخل النوع الأدبي بين السيرة الداتية والرواية في أدب الدكتور عبد الحميد بلدان}

\section{د/محمد عبد المطلب محمل جودة \\ (ابن الريف وابن الكاتب) نعوذجا}

كما لم يتحرج الكاتب من ذكره لمحاولات العبث الطفولي، التي كان يفرغ فيها طاقته الحبيسة: " وكنت أخنق الفراخ الصغيرة، وظني أنني ألعب معها " (')" وأظنني حدثلك يا بني عن لهن

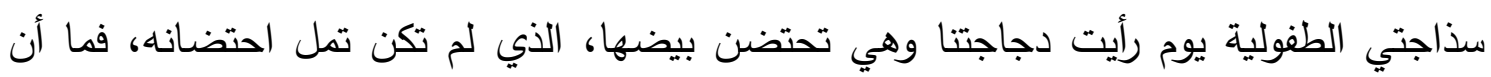

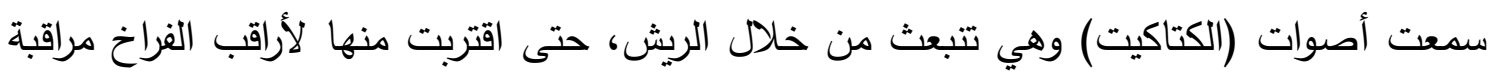
المشوق، ثم دفعني الفضول إلى نزع قشرة إحدى البيضات التي لم يخرج فرخها، وأنا لا أعلم أنها

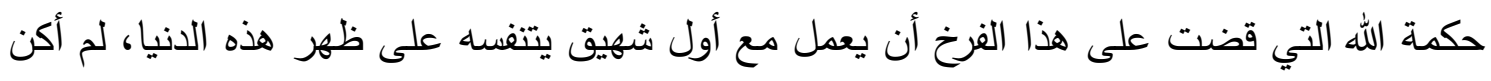

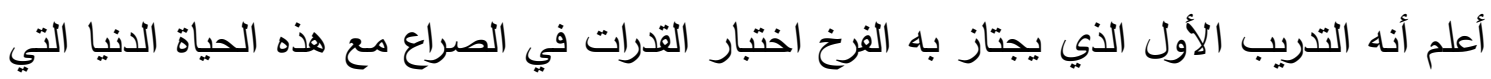

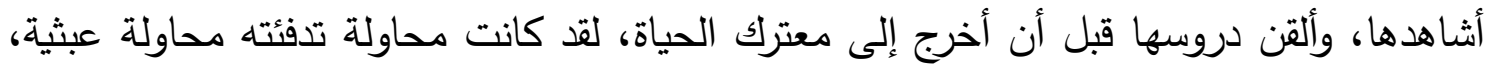

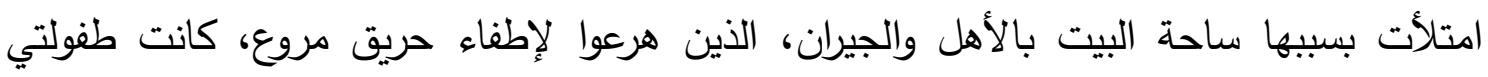

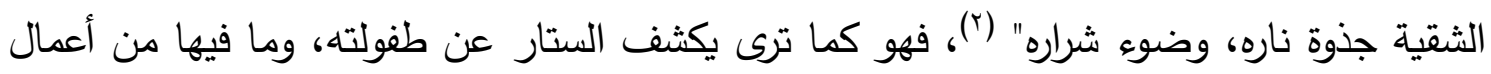
تخريبية، كادت أن تودي بحياة الأسرة.

ويقر كاتبنا ويعترف بعدم الوعي قائلا: " أما أنا فقد سطوثُ وأصدقاء الثارع على حقل بأطراف البلدة، كان يحوي العديد من الخضروات، ولم تكن هجمتنا إحدى ثورات الجياع الذين

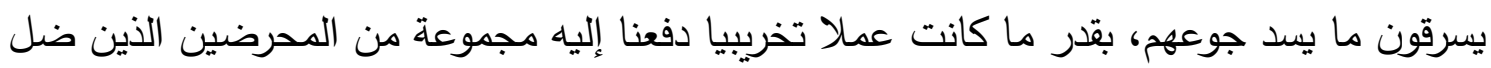

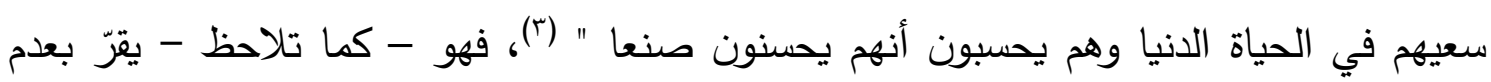
وعيه بالأحداث التي قام بها، ويوضّح أنه انساق وراء المحرضين والمخربين.

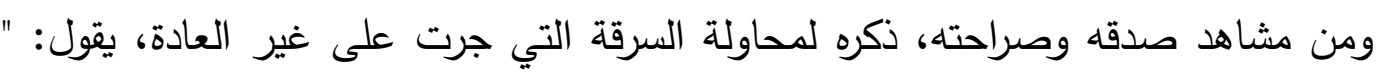

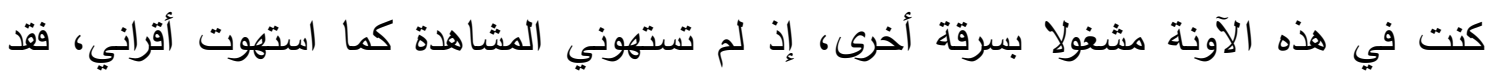

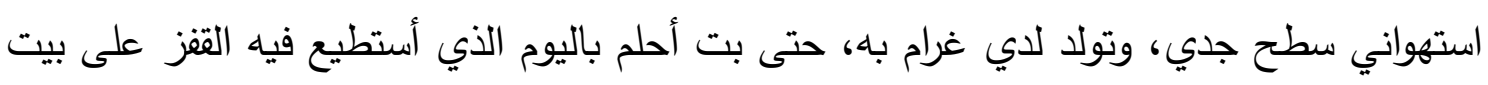

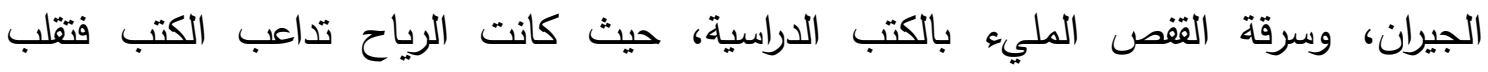
الصفحات، وتظهر الألوان الزاهية المصورة لملابس أمل وعمر وعمي حسن، فكان لا بد من فكرة

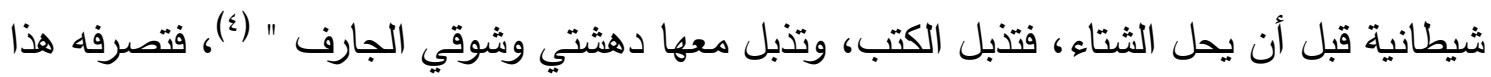

$$
\begin{aligned}
& \text { (1) (1) (بن الكاتب، ص00. }
\end{aligned}
$$

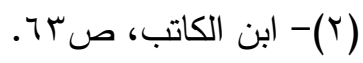

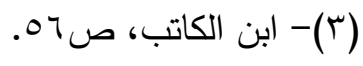

$$
\begin{aligned}
& \text { (ع)- ابن الكاتب، صهـ ـ 1. }
\end{aligned}
$$


- كما قرأت- تصرف طفل، لا يدري بحقيقة ما يصنع، لكنه في ذات الوقت يكثف عن حبه للعلم و وشغفه بالقراءة والاطلاع.

ولم يكتف كاتبنا بعرض حقائق ذاتيّة تتعلق به، بل تعدّى ذلك إلى الكثف عن وقائع تتعلق بأقاربه، فكثف عن: " الأحذية ذات النصف نعل التي كانوا يشترونها من سوق (الإثنين)، ورحلتهر لته

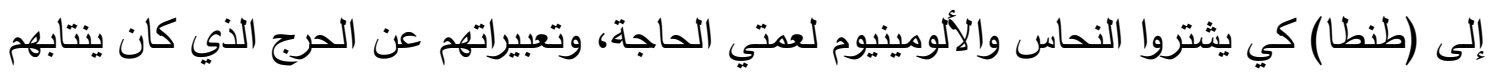
في سنوات الزواج الأولى، وهم يستحمون في (طشت) كائن في غرفة واحدة، كانت هي النوم

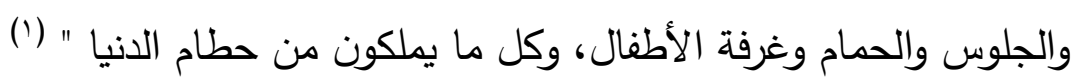

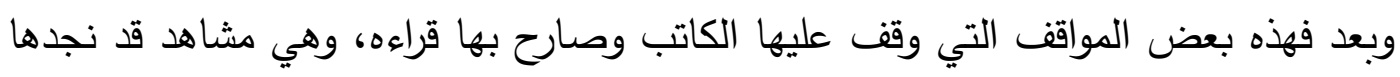

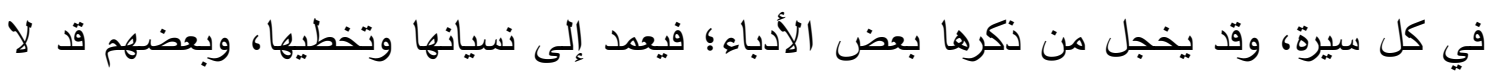

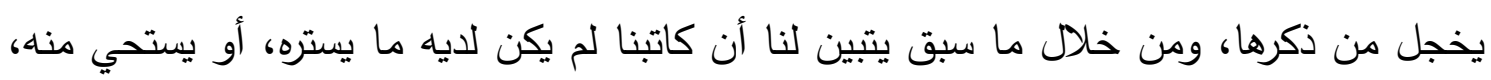
فالمواقف التي تحرى فيها الصدق والصراحة، تضيف إلى شخصيته ولا تتقص منها شيئا، وقد رأينا

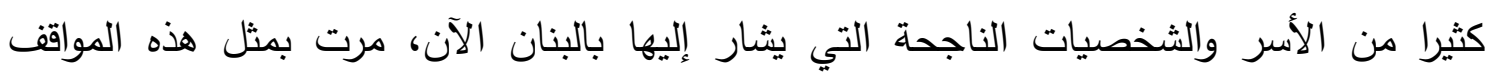

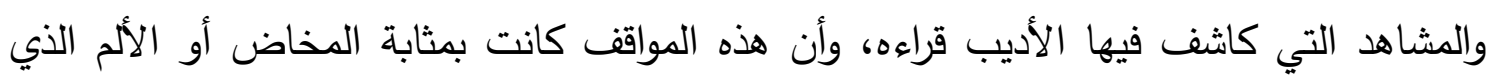
يسبق الإبداع.

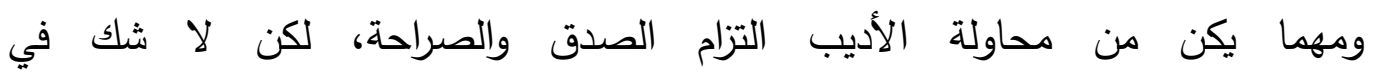

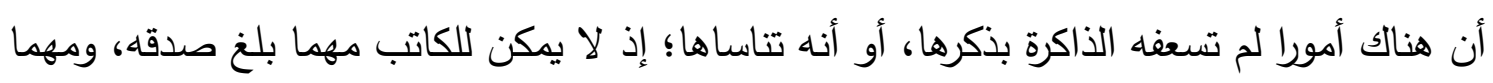
بلغت صراحته أن يكتب كل ما يعرض له في في عاله الهه الخاص. 


\section{تلاخل النوع الأببي بين السيرة الداتية والرواية في أدب الدكتور عبد الحميد بلدان}

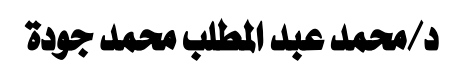

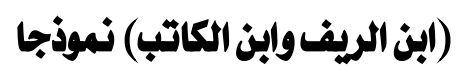

المبحث الثاني: الميثاق الروائي

إن تعبير الكاتب عن تجاربه الخاصة وبلورتها من خلال عنصر التخييل، وتغييره لبعض الوقائع والأحداث، وتمويهه بذكر أماكن وشخصيات بديلة، ليس معناه الانسلاخ من ميثاق السيرة

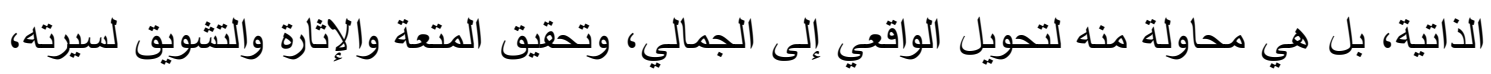

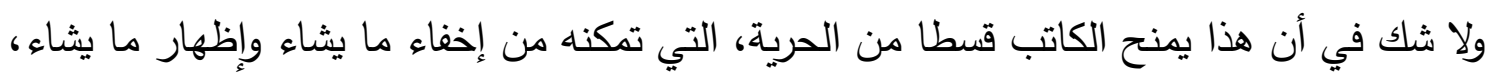

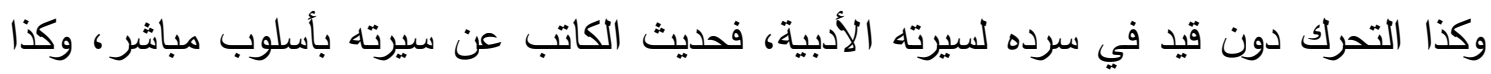

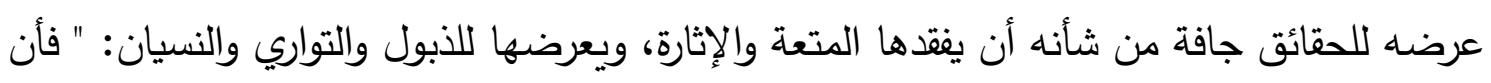
تتحول سيرته الذاتية وفق الانزياح الجمالي إلى ملحمة شعرية أفضل من أن أن تبقى تقريرية، وأن

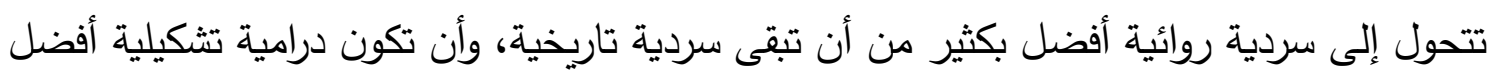

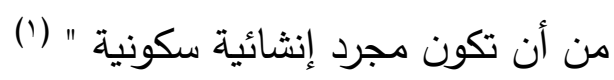

لذا فإن معانقة الخيال للحقيقة أمر محمود من شأنه أن يخفف من جفاف الحقيقة، ويساعد على تجاوز الفترات التي لا أهمية لها في حياة الثخصية، فسلاسة التعبير ، ورشاقة العبارة، وتتامي

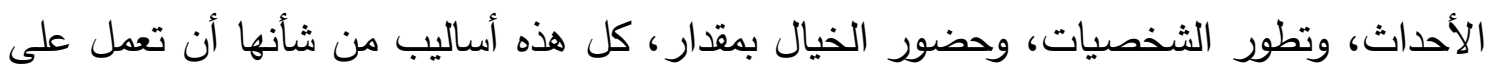
إغراء القارئ بالاستمرار في القراءة والمتابعة، وتسهم في بناء سيرة ذاتية أدبية، ناجحة ومؤثرة. والسؤال الآن: ما مدى التباس الرواية بالسيرة الذاتية في نص (ابن الريف، وابن الكاتب)؟ أو أو التوان

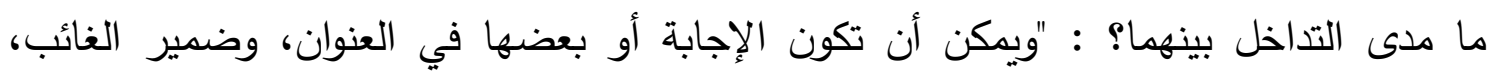
واختلاف اسم الثخصية، والخيال والانتقائية وما إلى ذلك؛ بكعنى الإبه أو بعضى أن تدخل السيرة الذاتية المجال

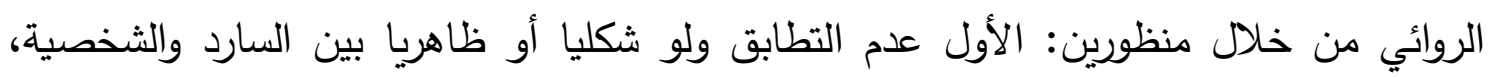

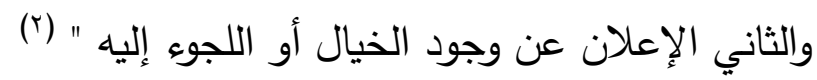

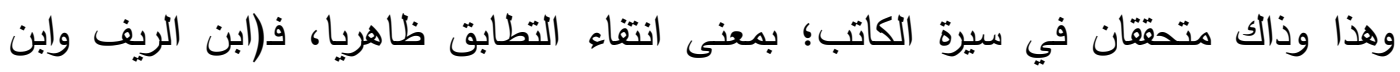

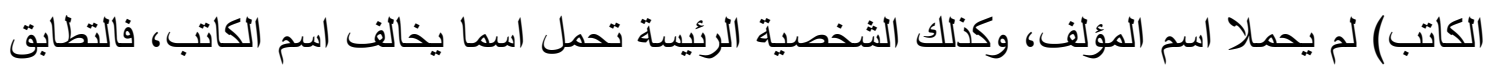
معدوم في الظاهر متحقق في الباطن، إذ هناك - كما سبق وبينا- في سيرة الكاتب آثار مباشرة

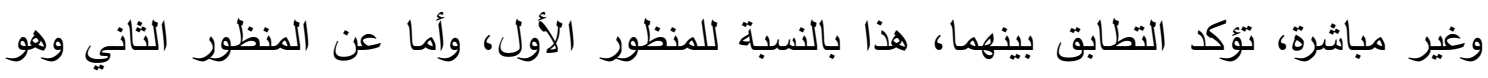

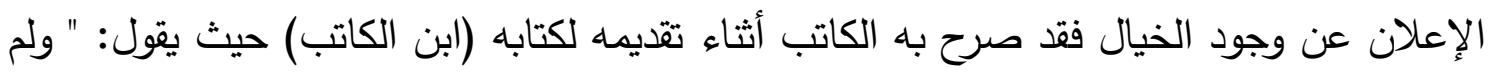
يدر في خلدي وأنا أخط أولى صفحات (ابن الريف) أنني في طريقي لإنجاز سيرة بطعم الرواية،

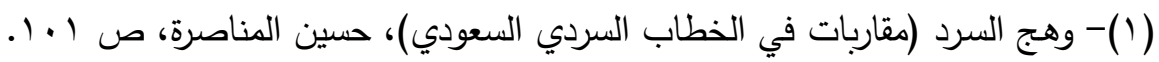

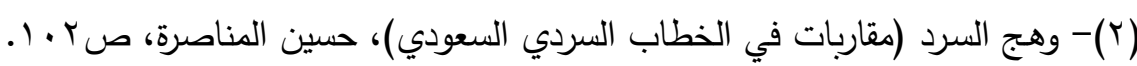


بعد أن أيقنت أن الصدق المطلق في سرد السيرة الذاتية يعد ضربا من ضروب الخيال، وأن كاتب

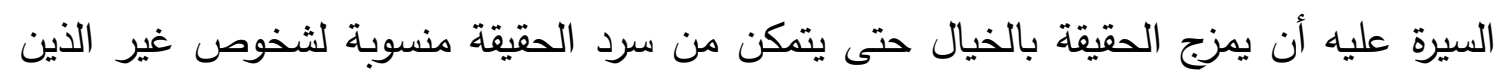

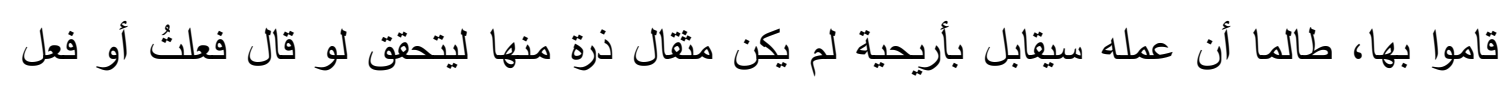
فلان.

إنني ما زلت أتساءل حتى اليوم، ماذا كنت أريد أن أصنع هناك؟، أكنت أحاول الرواية فجاء

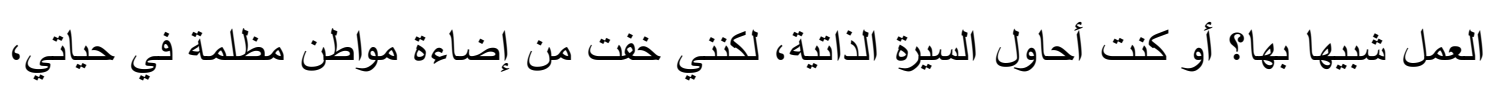

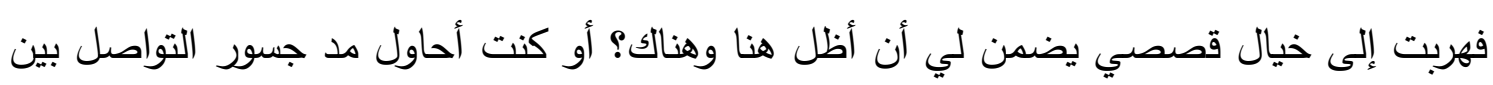

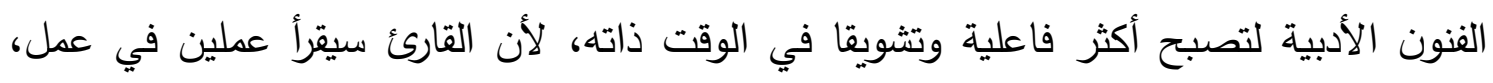

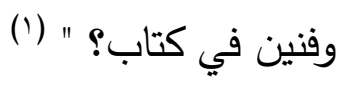

فالتواصل والتداخل بين السيرة والرواية متحقق في (ابن الريف، وابن الكاتب)، ومن ثم فهما

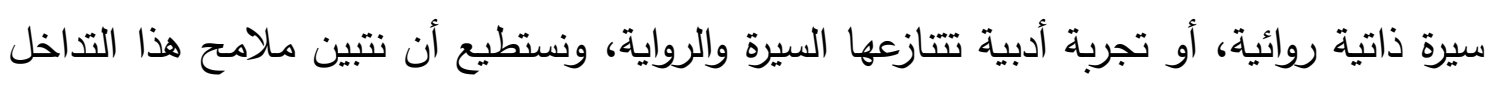

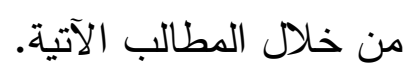




\section{تلداخل النوع الأببي بين السيرة الثاتية والرواية في أدب الدكتور عبد الحميد بلدان \\ د/معل عبد المطلب محمل جودة

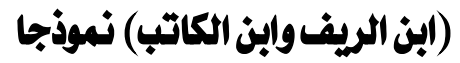

الحقيقة والخيال

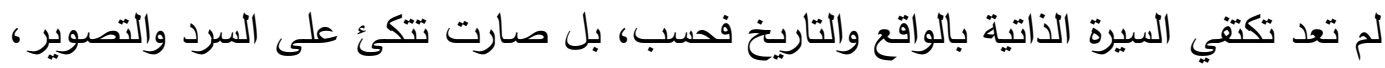

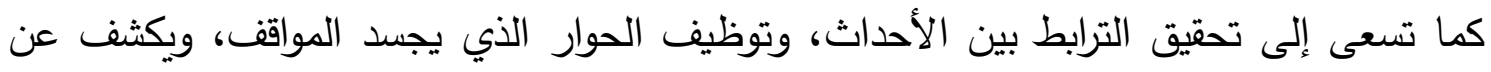
بواطن الثخصيات، وكذا استخدام الخيال الذي يحقق لها الإثارة والتثويق والمتعة الجمالية، حتى التى

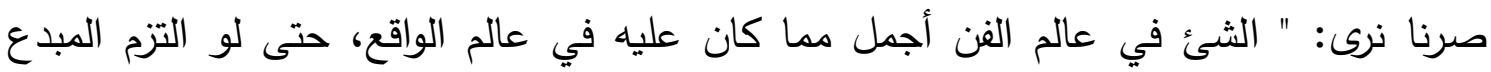

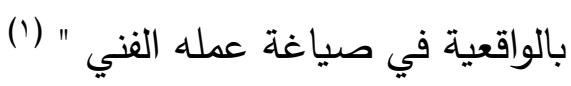

وإذا كانت السيرة الذاتية فنا يعتمد على الحقائق، والرواية فن يعتمد على الخيال، فإن للخيال

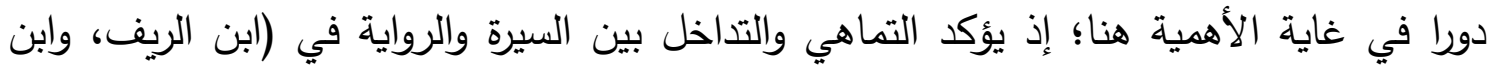
الكاتب)، كما يرقى بالسيرة الذاتية من مظاهر السرد التاريخي الرتيب، وتبعثر الأحداث وتنككها؛ مما يمنحها عنصر التثويق والجمال. ويلجأ كاتب السيرة الذاتية إلى الخيال؛ نظرا لصعوبة تذكره لأيام طفولته؛ إذ إن تذكر هذه: "

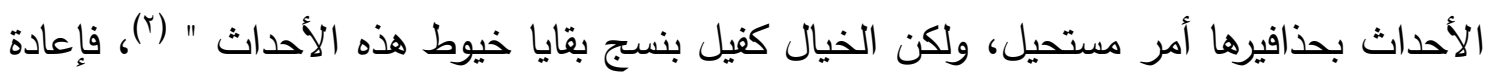
صياغة هذه الأحداث، وابتكار أسماء جديدة للشخصيّات، والاستعانة بأوصاف تختلف عن تلكن التكان

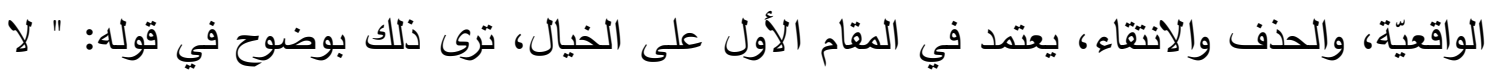

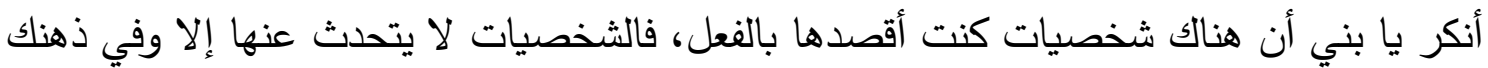

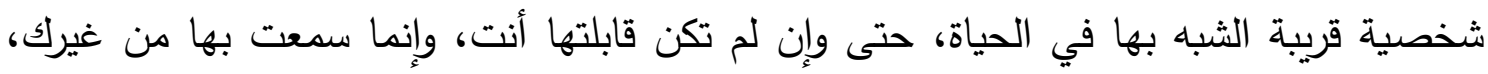

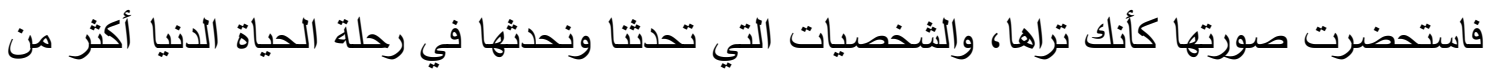
أن يحصرها عد، فهي تختلف هيئة وسلوكا ووظيفة، وطبيعة، ومزاجا، مما يجعل الفرصة أمامك

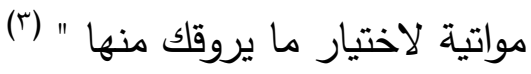

فهو - كما ترى - يسعى للارتقاء بسيرته بشكلها الواقعي الحقيقي بما تحتويه من أحداث

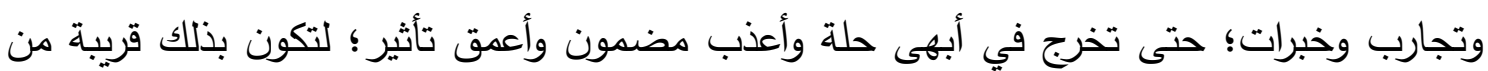

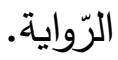

(1)- السيرة الذاتية في الأدب العربي الحديث (رؤية نقدية)، د. شعبان عبد الحكيم ححم، ص. • ا، مؤسسة الوراق

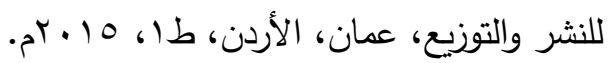

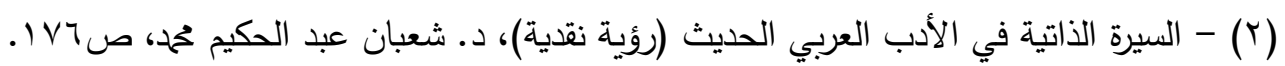

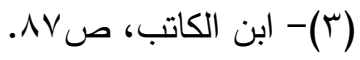


وتستطيع أن تقف على بعض مظاهر الخيال التي وظّفها الأديب في كتابيه (ابن الريف، ابن

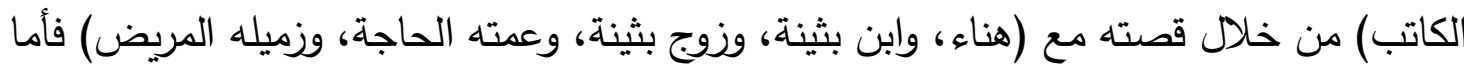

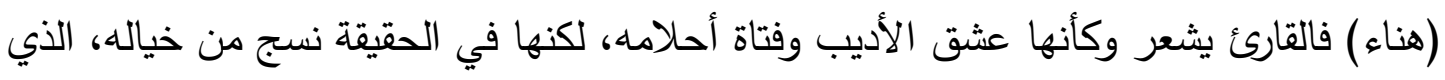

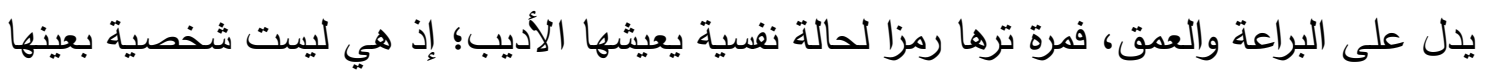
وترى ذلك في قوله: " ويعرفون أن (هنا) هي سلوى، ونجوى، ونداع ونوال، ورقية، وهالة، وكل الأسماء

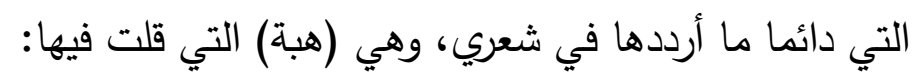

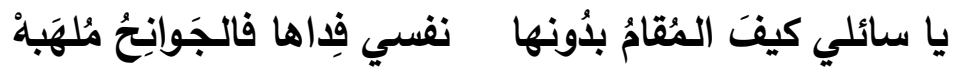

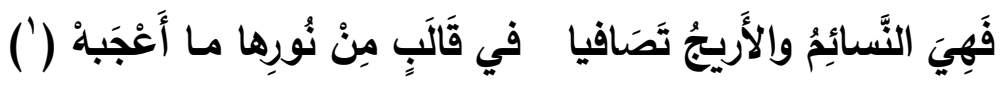

ومرة تراها رمزا لصفاء الريف وبساطته، يقول: " ربما كان ميلي لـ (هنا) سببا في ارتباطي

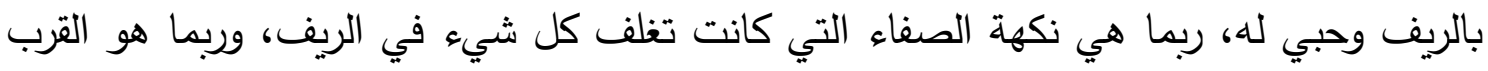
من مفردات الطبيعة أرضها وسمائها وحيوانها وطيرها، وعشبها وخضرواتها وحبوبها، وحطبها تهاتها

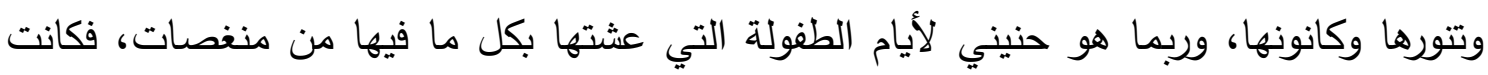

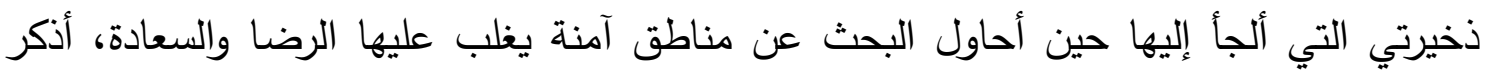

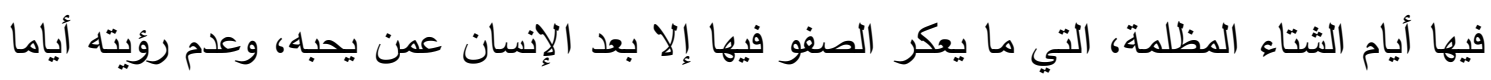

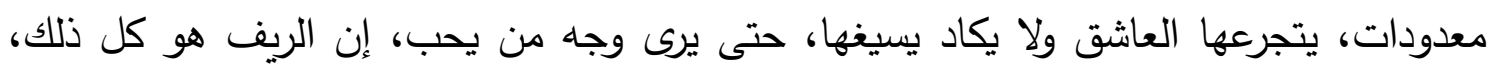

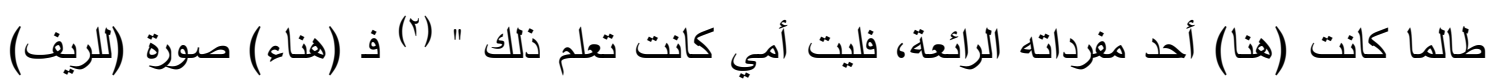
الذي يعيش في أعماقه، وطيفه الذي لا يفارق خياله، وينتقل معه في جميع مراحله.

وربما كانت (هنا) هي العاطفة والدافع وراء الكتابة، تلمح ذلك في قوله: " أتاني صوتها

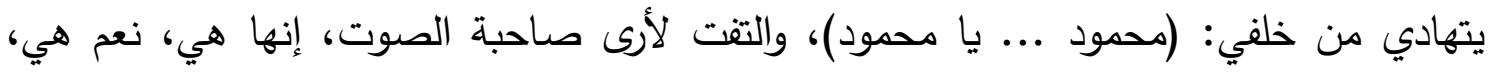

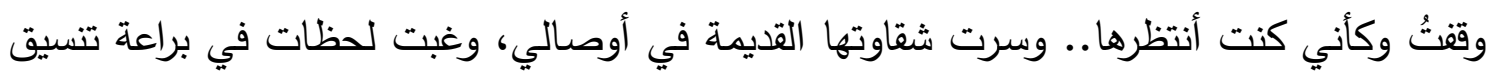

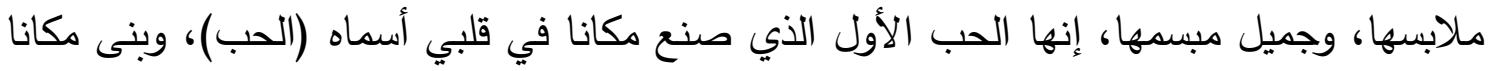

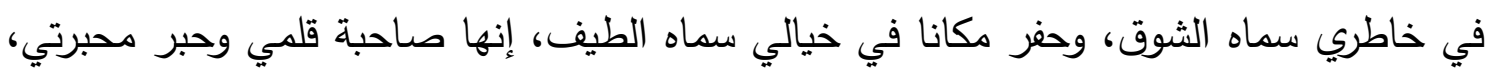

$$
\begin{aligned}
& \text { (1) - ابن الريف، صع 9،، } 90 . \\
& \text { (Y) - ابن الريف، ص • آن. }
\end{aligned}
$$




\section{تلاخل النوع الأدبي بين السيرة الداتية والرواية في أدب الدكتور عبد الحميد بلدان \\ د/محمل عبد المطلب محمل جودة \\ (ابن الريف وابن الكاتب) نعوذجا}

وقنديل ليلي" (')، ف(هنا) هنا هي دوافع الثاعرية والكتابة التي تناديه، وتهيئه للإبداع، وتحثه عليه، ومن ثم ف(هناء) هنا شخصية خيالية، استخدمها الأديب لدوافع عدة كما رأينا.

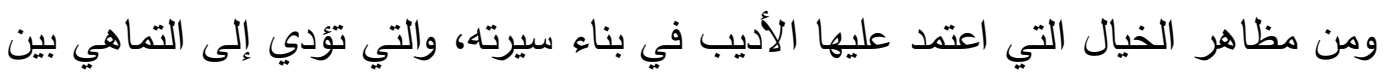
السيرة والرواية شخصية (ابن بثينة) التي نسجها من خياله وما صاحبها من أحداث وحكايات، أراد الأديب من خلالها أن يعكس صورة الثائعات، وسرعة انتثارها، ودورانها على ألسنة الناس -

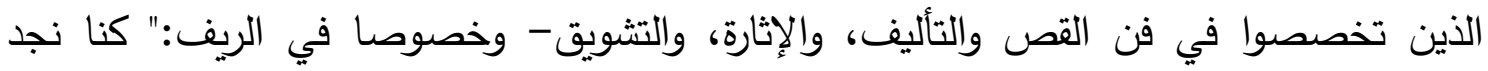

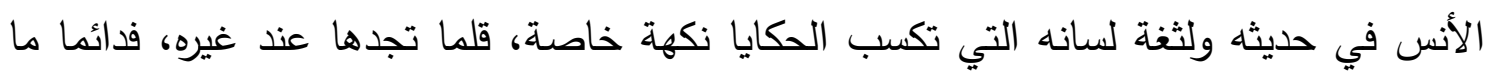
يصدر الخبر منه مشفوعا بأسانيده الواهية، التي ورثها عن أمه الخالة (بثينة)، كنا نتحمل تدخينه

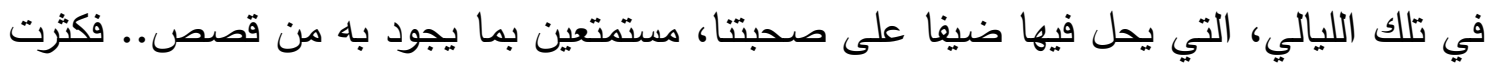
حكاياه وطابت أقاصيصه، فله في كل ليلة حديث، وفي كل حدث قصة، ولكل أمر تعليل محبوك"(()، فاختلاق الأديب لبعض الثخصيات، وتوظيفها، وإجراء الحوار بينه وبينها، وتحليله

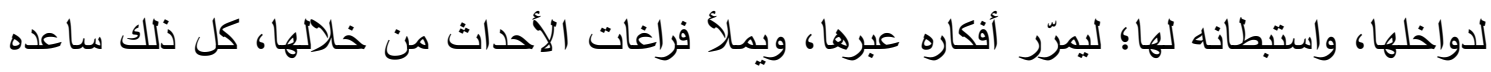

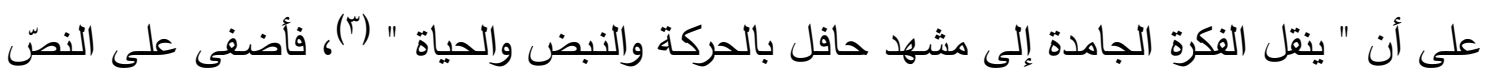

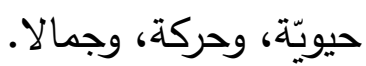

ومن الخيال أيضا اختلاقه لموقف الدكتور (حسن) زميله في السعودية: " وذهبت وزوجتي في

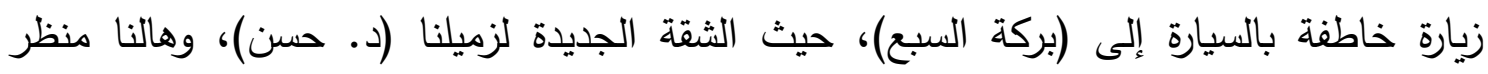

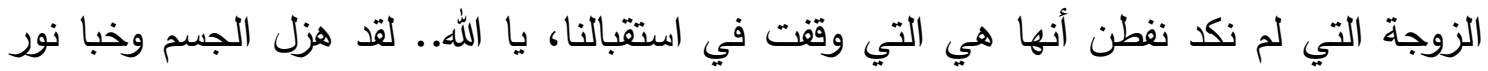

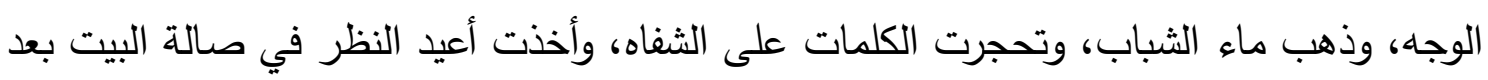
أن أخذت مجلسي على كرسي فخم، فوقفت عيني على لوحة كبيرة مكتوبة بخط ديواني يصعب أنساء

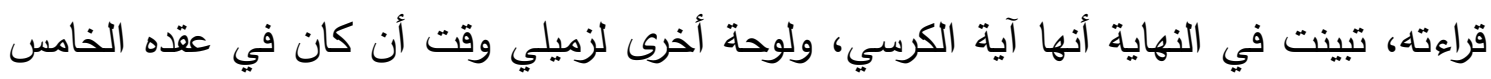

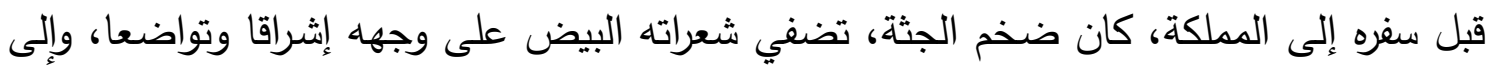

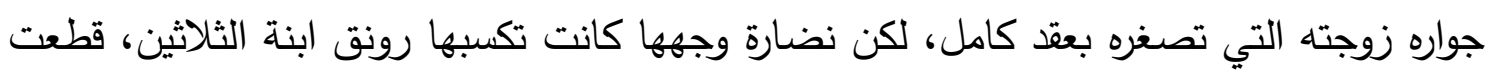

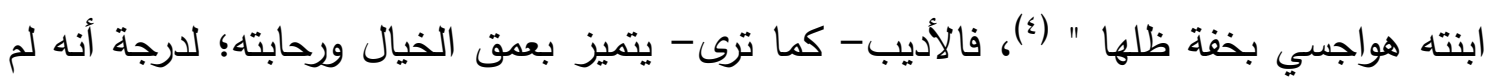
يفارقه حتى في توثيق سيرة حياته.

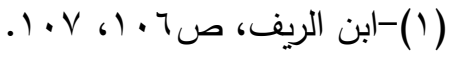

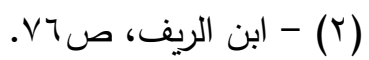

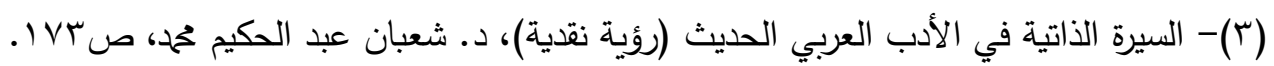


ولا يقتصر الخيال عند أديبنا على الثخصيات غير الحقيقية أو الختلقة، بل تعداها إلى

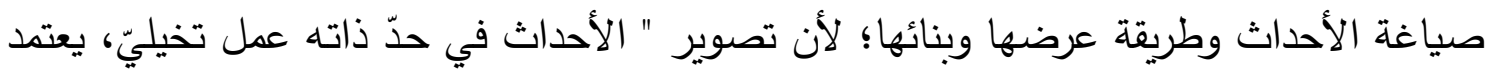

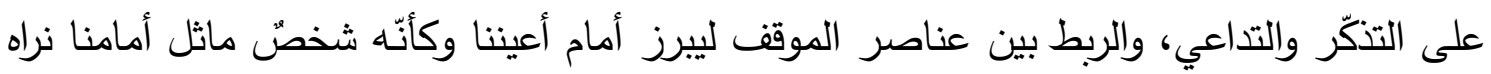
رأي العين، وفي استبطان الكاتب لمشاعره ولداخله، ولمشاعر غيره الباطنية "((') يلعب الخيال دورا

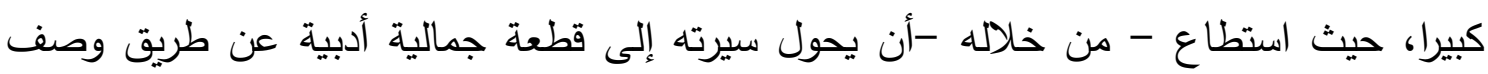

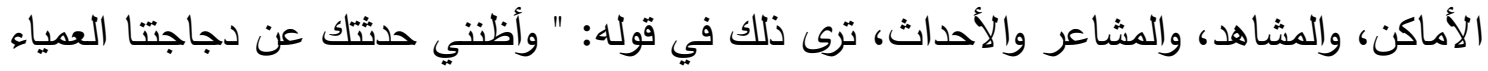

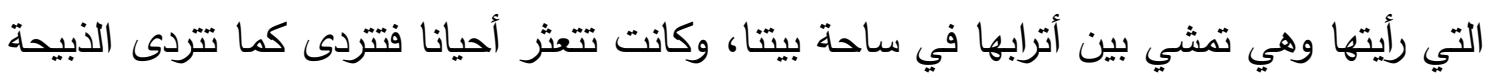

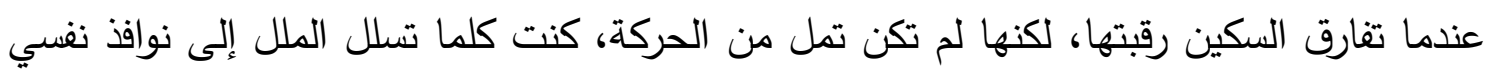

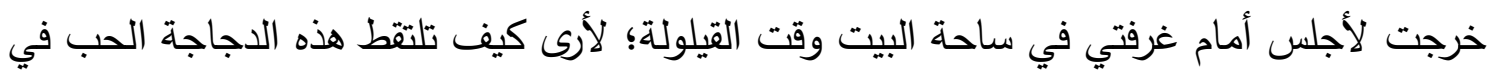

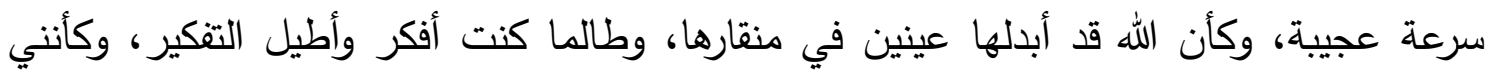
أحاول استدعاء بيت شعر من ذاكرة الثعر العربي التي طالما أسعفتني بكل طريف، وكأ وكأن ما أراه

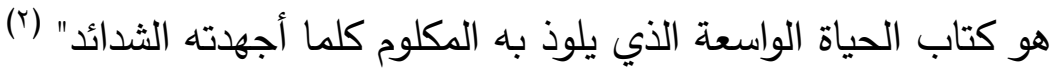

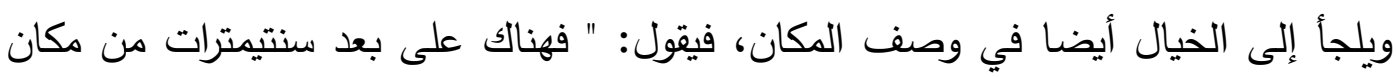
الوالد (أبو العز)، يستقر معبر طيني بسيط، يفصل الثجر العتيق عن غرفة نائية، معدة لاستقبال

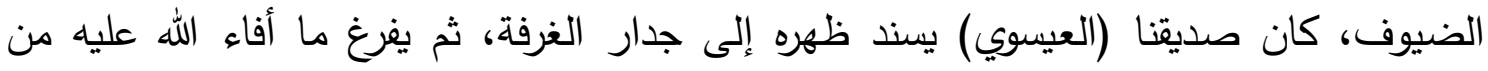

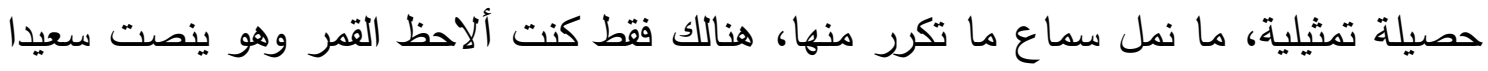

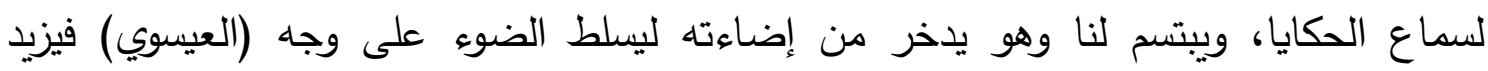

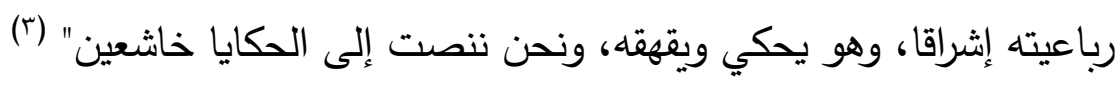

ومن ذلك أيضا استخدامه للخيال في وصف بعض المشاهد الريفية التي عايشها في طفولته "

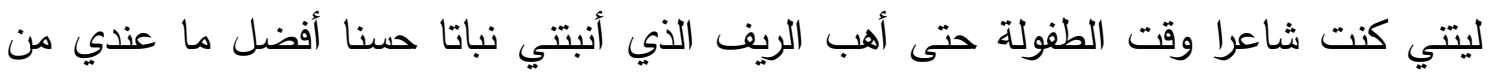

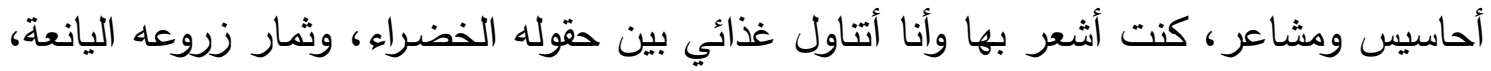

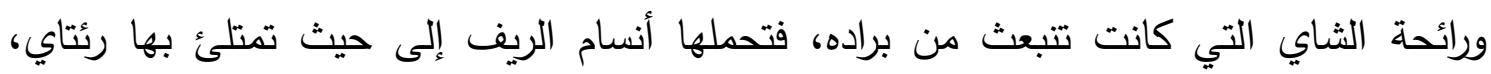

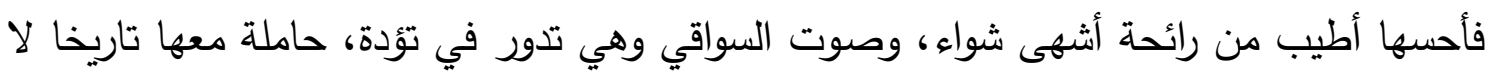

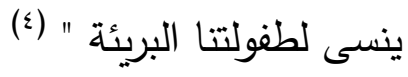

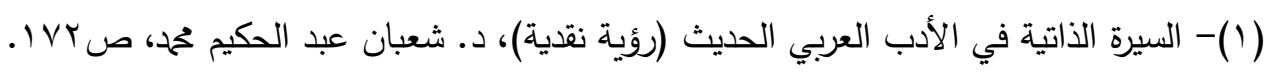

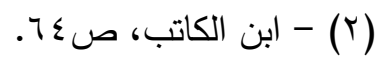

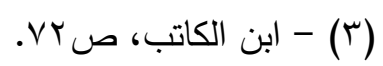

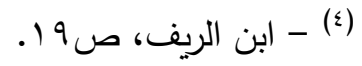




\section{تلداخل النوع الأببي بين السيرة الثاتية والرواية في أدب الدكتور عبد الحميد بلران \\ د/محمد عبد المطلب محمل جودة \\ (ابن الريف وابن الكاتب) نعوذجا}

ومن العناصر الخيالية التي تدني السيرة الذاتية من الرواية أيضا تلك القصص التي يجتمع

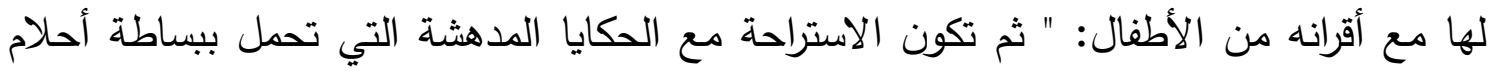

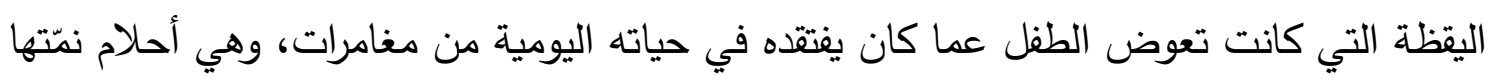

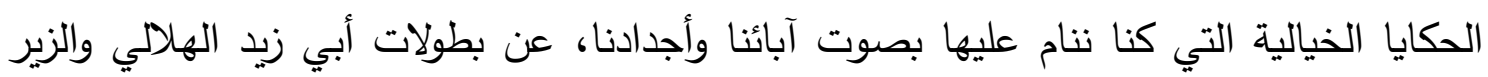

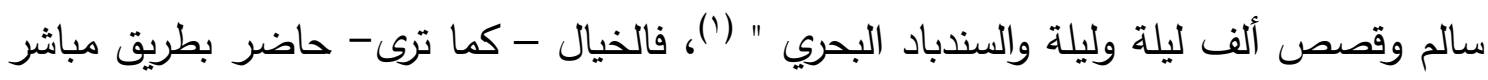
وغير مباشر ؛ إذ هي بلا شك قصص تعتمد على الخيال في المقام الأول. ومن ذلك أيضا، يذكر أولاده بما لذ وطاب من الأحاديث الثيقة، والحكايات العجيبة، يقول: " فأنت تذكر يوم قصصت عليك قصة البطلين (محمد وأحد) اللذين حاربا (التتين) اللعين، فصارا

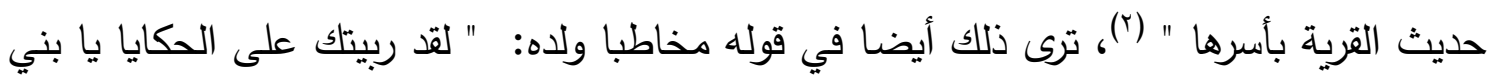
مذ كنت جنينا في رحم أمك، فقد كان لها في كل ليلة عرض سينمائي، أصنعه من خيالي، وأنتجه

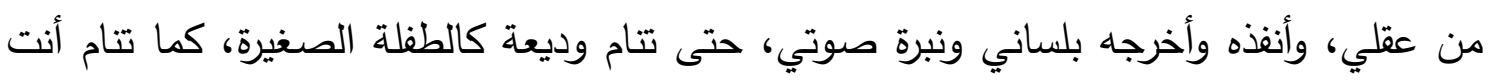

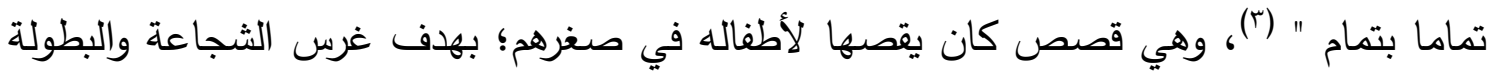

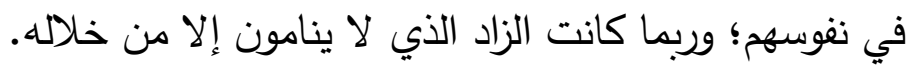

ناهيك عن توظيفه للخيال عند وصفه لـ (هناء)، أو لغيرها من المواقف والتجارب من خلال

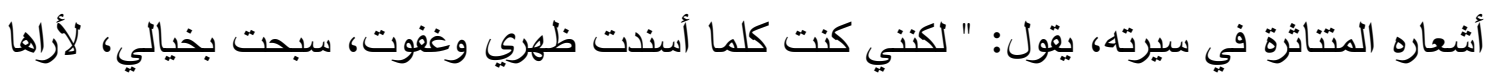
أمامي وكأن البعد قد فجر فيّ طاقات كامنة من الثوق، فكتبت وقتها:

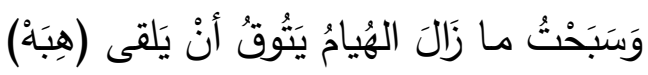

وَبِِيقَها المَعْسولِ يُروَى فَالأمَاني مُتَعَبْهُ

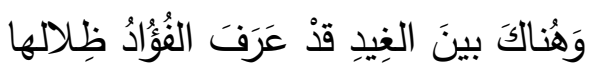

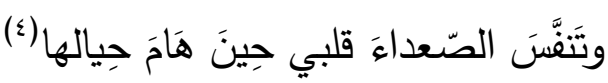

ومعلوم أن الثعر يستسلم فيه الثاعر لليلته التي تمده بالصورة تلو الصورة، والصشهد تلو

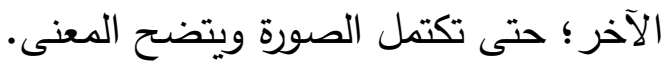

$$
\begin{aligned}
& \text { (') - ابن الكاتب، صعـ ـ (1) }
\end{aligned}
$$

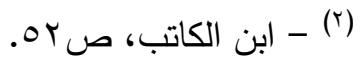

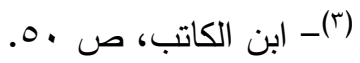

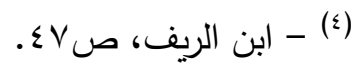


وصفوة القول إن الأديب هنا - وإن كان يحكي أحداثا واقعية تتعلق بحياته - قد استعان

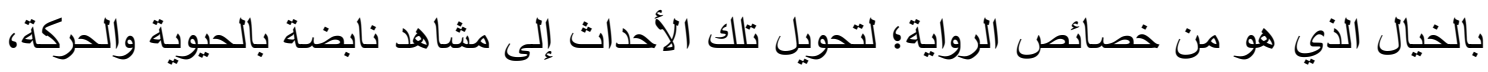

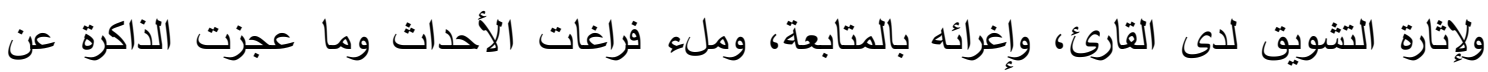
إدراكه؛ مما أحدث التماهي والتداخل بين السيرة والرواية. 


\section{تلداخل النوع الأببي بين السيرة الثاتية والرواية في أدب الدكتور عبد الحميد بلران}

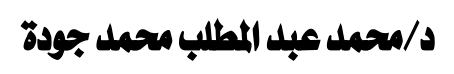

(ابن الريف وابن الكاتب) نعوذجا

الثخصية

إن الثخصية في السيرة الذاتية شخصية حقيقية تعيش الواقع في الغالب، أو قرببة منه،

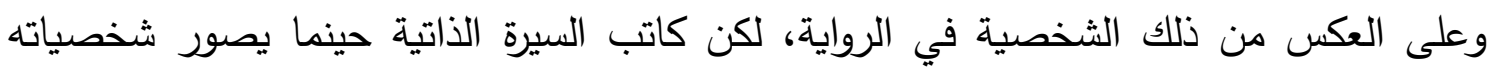

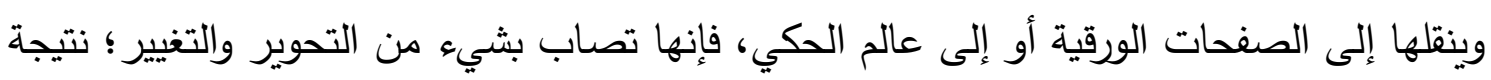
جعلها حية ومتحركة، وقوية الحضور والتفاعل، ولن يتيسر ذلك للأديب إلا إذا استبطن طواياها لهانيا

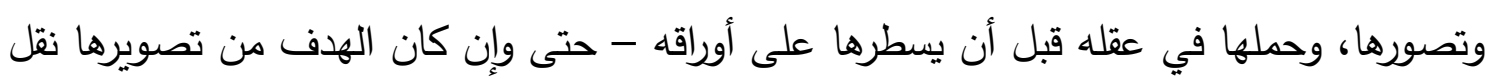

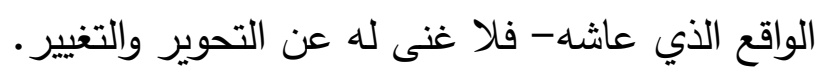
ومن ثم فإن هذا التغيير والتحوير والتصور لهذه الثخصيات، هو الذي يكسوها بجوار

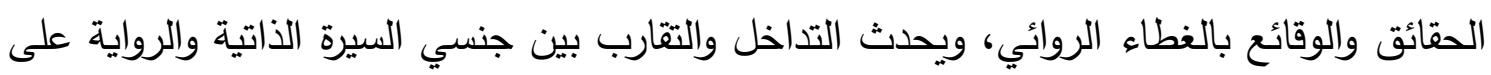
مستوى الثخصية؛ بما يخلعه عليها من موروثات ثقافية، وسلوكيات اجتماعية ونفسية وخيالية. وعند النظر في شخصيات السيرة الذاتية لاى الأديب (عبد الحميد بدران) نجد أنها تمتح من معين الرواية الكثير والكثير، فعلى سبيل المثال حينما نتأمل تصويره لثخصية (عمتي الحاجة)

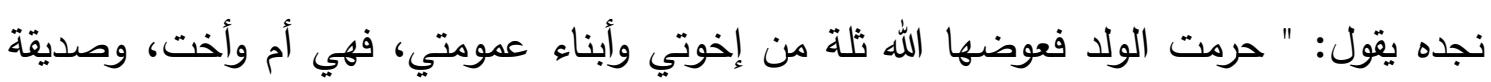

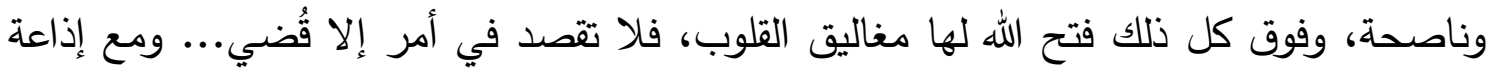

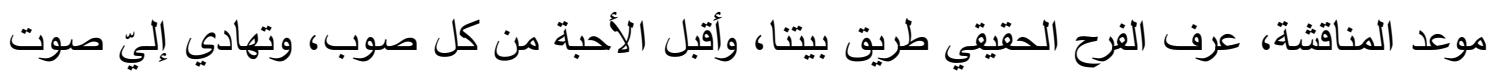

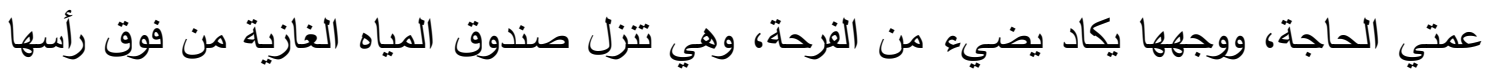
كفتاة عشرينية:

. ألف مبروك يا نور عيني.. ألف مبروك يا دكتور.. أنا نفسي في اليوم ده من زمان.. أنا

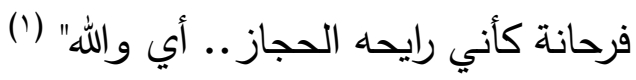

إن شخصية (عمتي الحاجة) من الثخصيات المحببة إلى نفس الأديب، وتبدو من خلال

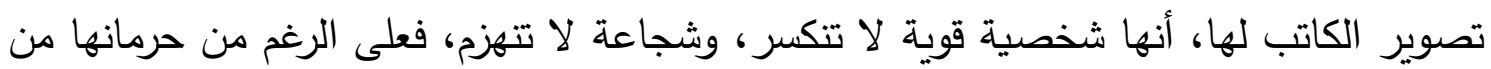

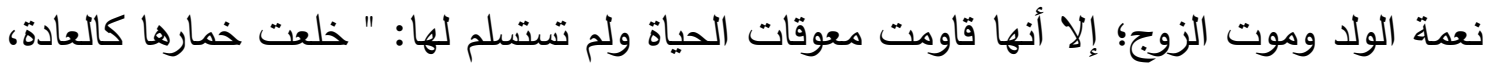

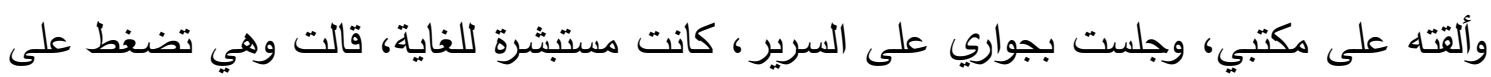

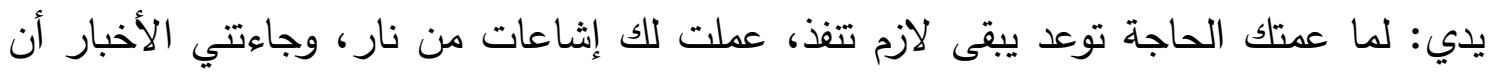

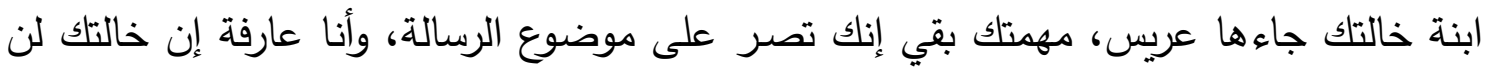

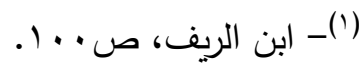


تطيق انتظار سنة واحدة " (1)، كما أنها شخصية مرحة وجريئة ومتحركة، فقد استطاع الأديب أن

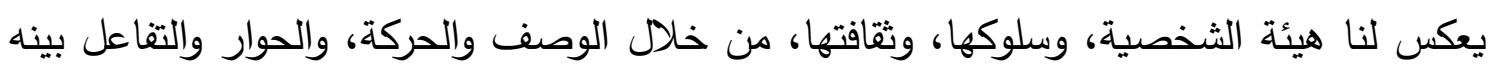

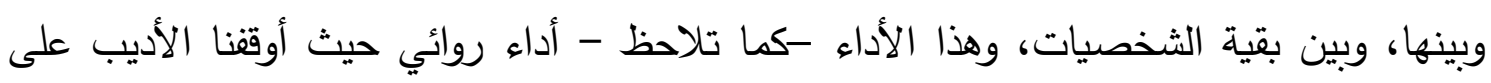

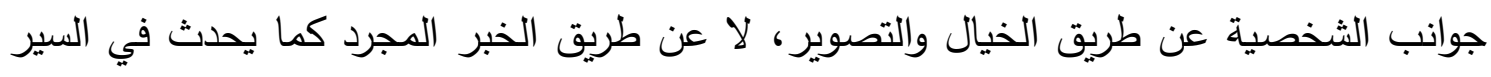
والتزاجم.

ومن هذه الثخصيات التي مزج فيها الأديب بين الواقع والخيال، فأخذت طعم الرواية وحسها،

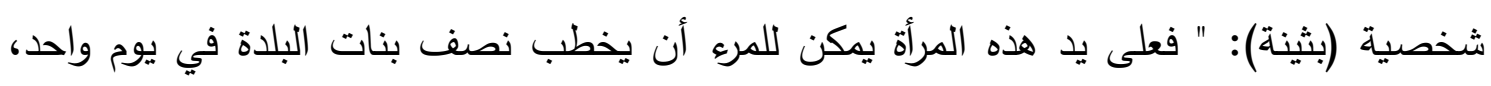

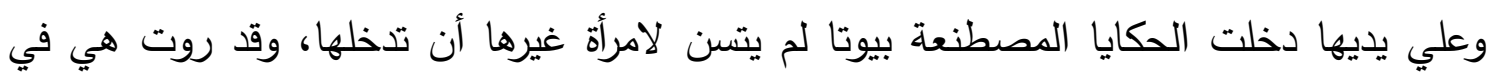

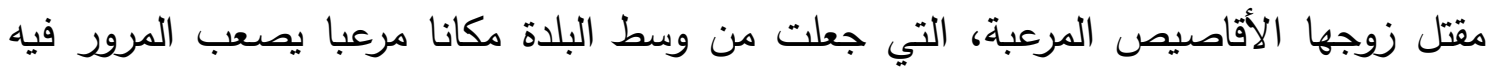

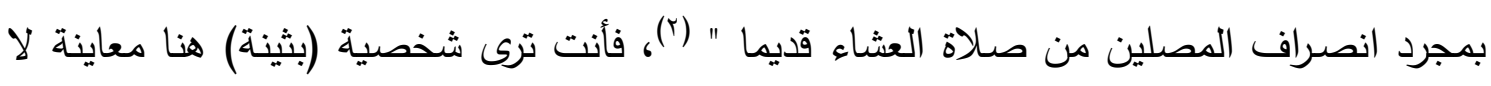

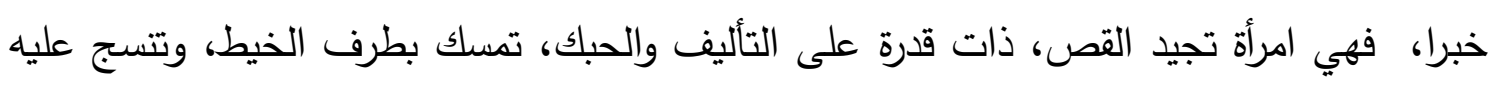
خيوطا.

ويمزج بين السيري والروائي فيصورها من خلال الحوار الذي يسهم في تطوير الأحداث،

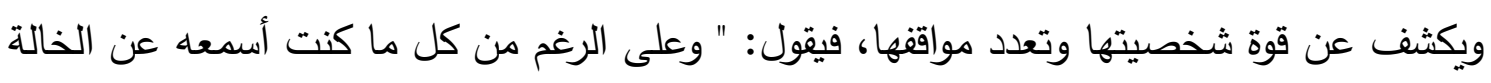

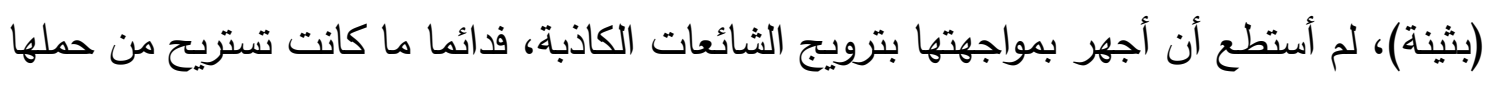
الثتيل في رحلة العودة من السوق على سلم بيتنا، من أجل مواصلة الرحلة إلى بيتها بأقاصي القرية، وبينما كنت أنتظر عودة أمي وأختي من السوق في أحد الأيام مرت الخالة (بثينة) واضطررت للنزول استجابة لإشارتها ففاجأتني بقولها:

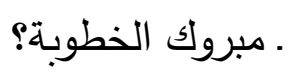

. مارك الله فيك، ومن العروس؟

. واحدة قريبتاك أكيد، عمك اسماعيل قال لي ليلة الحادثة.

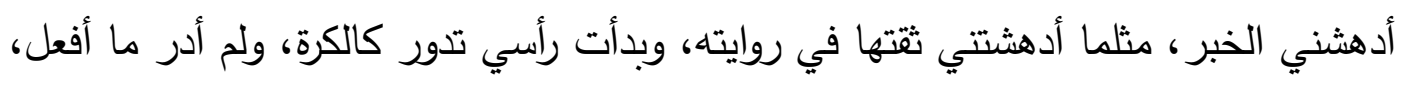

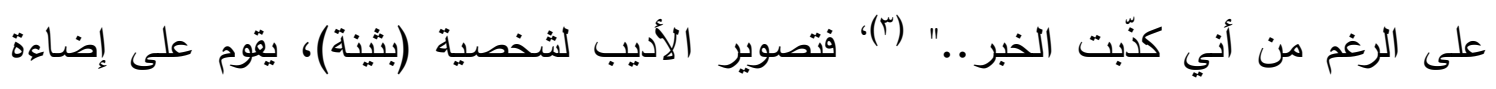

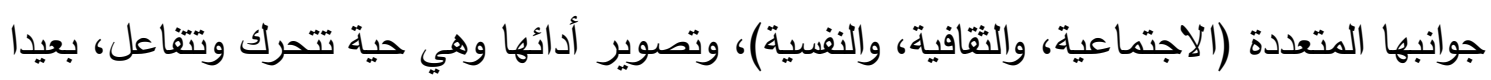

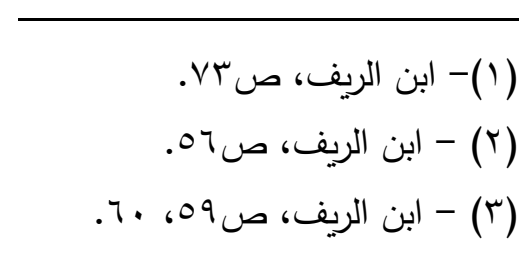




\section{تلداخل النوع الأببي بين السيرة الثاتية والرواية في أدب الدكتور عبد الحميد بلدان

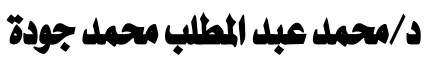

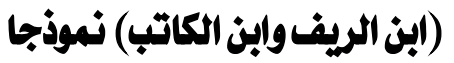

عن خبرها التسجيلي أو الدجرد كما يحدث في السيرة والتراجم، ومن ثم استطاع أن يصور ظاهرة انتشار الثائعات - في الريف خصوصا- من خلال هذه الثخصية، والتي كان أحد ضحاياها.

ومن هذه الثخصيات التي رسمها الأديب بالطريقة الدرامية أو بطريقة الرواية شخصية (جده

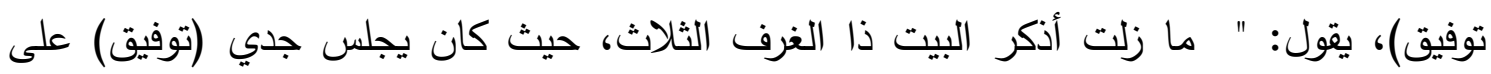

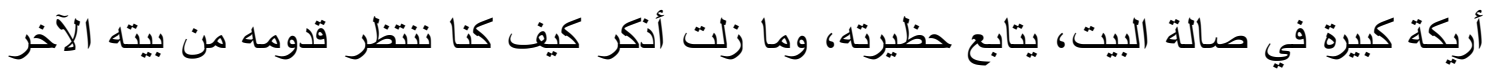

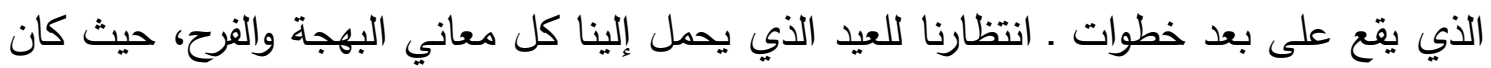

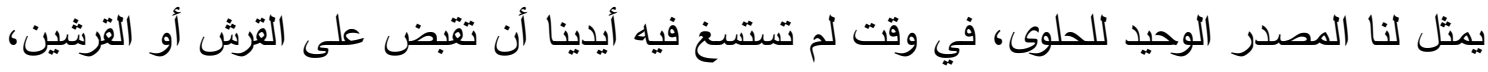

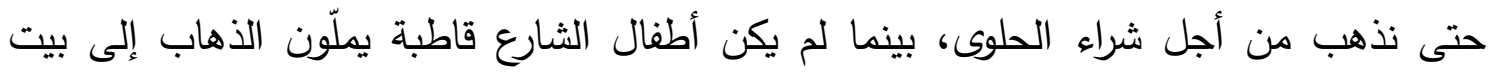

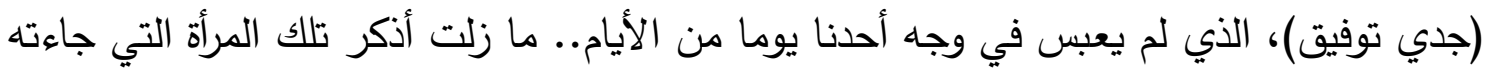

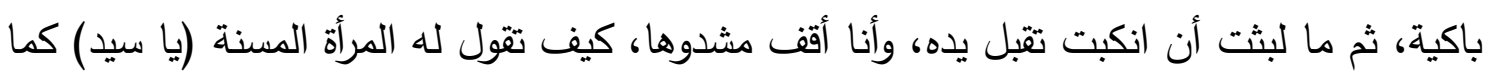

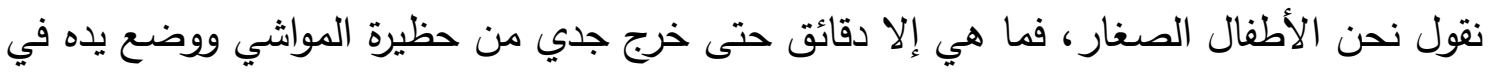

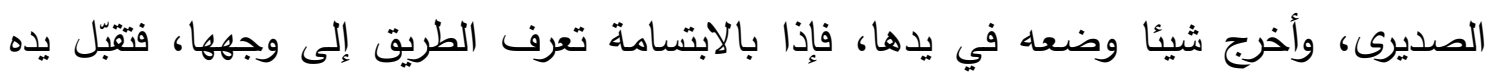

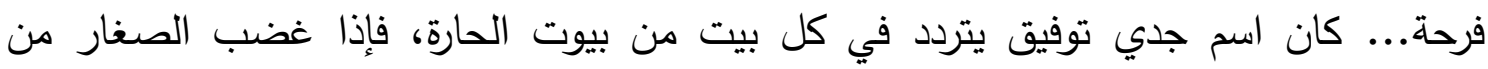

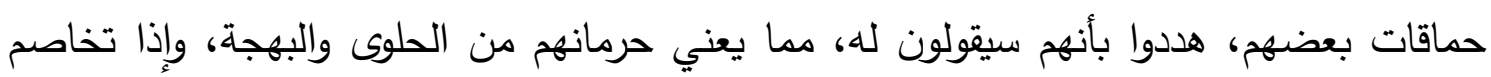

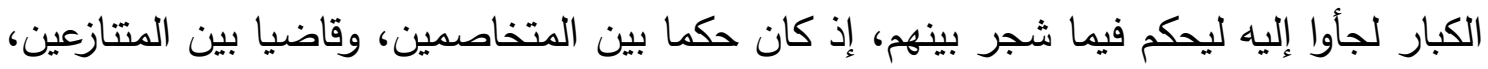

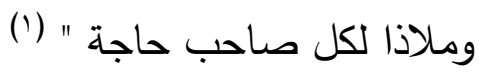

فأنت تتعرف على شخصية الجد (توفيق)، من خلال الحدث، حيث يقدم الثخصية - على طريقة الرواية - وهي تتحرك داخل عملها القصصي، وتتمو بنمو الحدث نفسه، وتتراكم دعلوماتنا عنها شيئا فثيئا، فالجد توفيق مرة (يجلس جدي (توفيق) على أريكة كبيرة في صالة البيت، يتابع

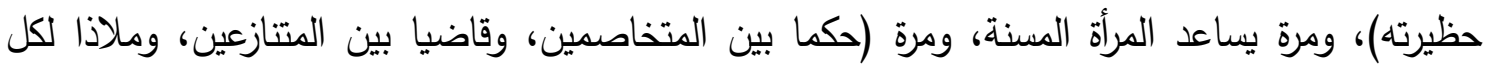

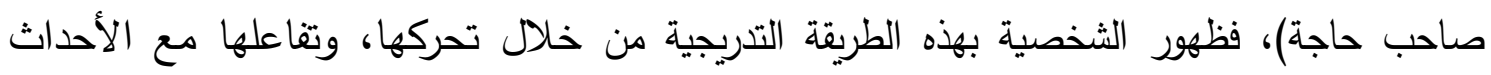

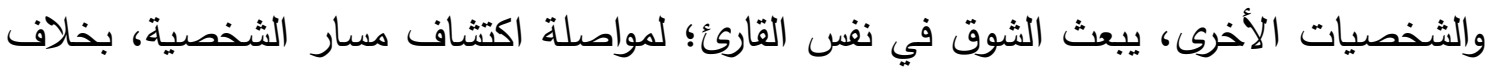

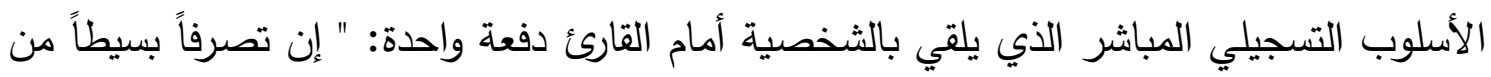

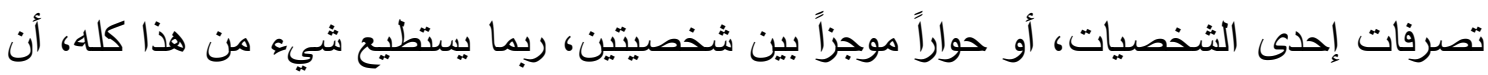

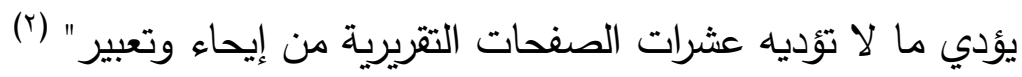

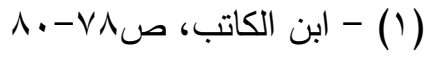

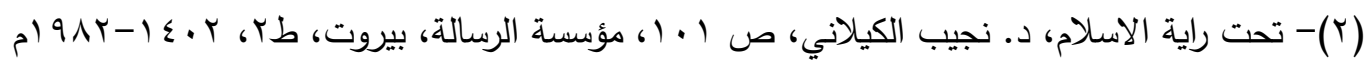


وعن طريق الحوار والحدث، يطلعنا على شخصية (هدى): " هرعت والدتي إلى الثارع كي

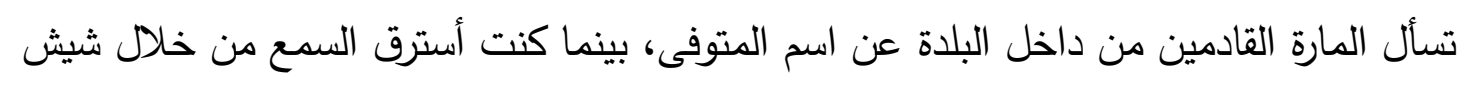

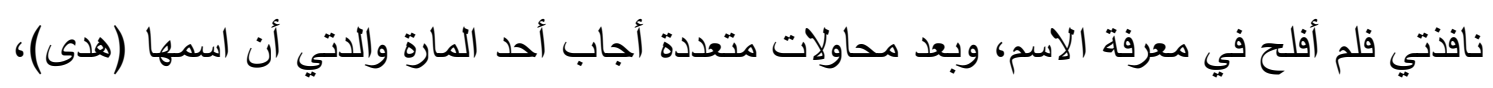

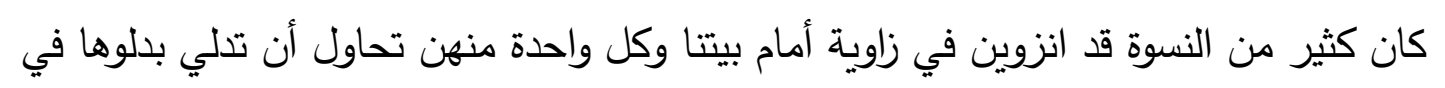

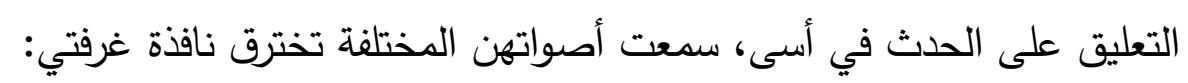

. هدى النجار .. يا لهوي.. أنا شيفاها امبارح.

. الموت بيختار يا أولاد.. دا عيّلة صغيرة.

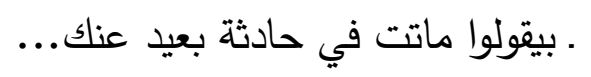

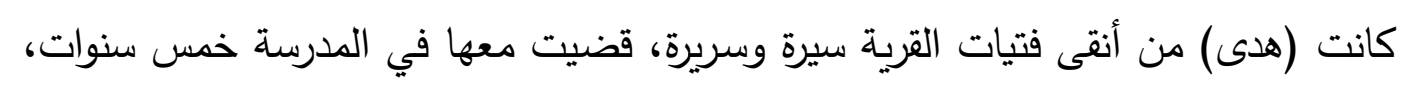

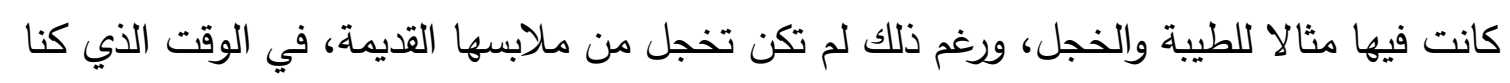

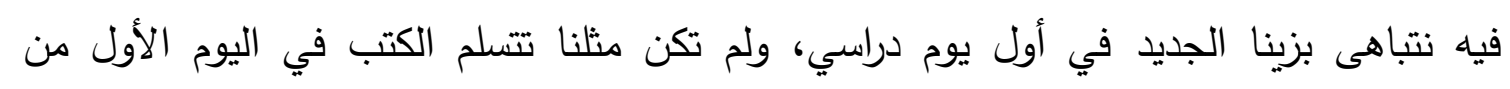

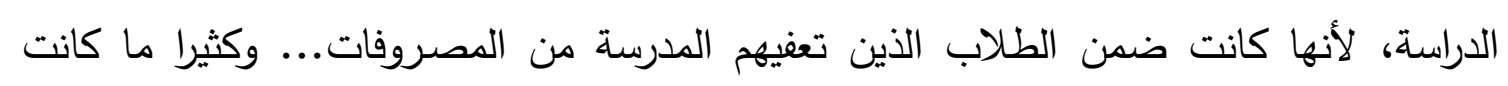

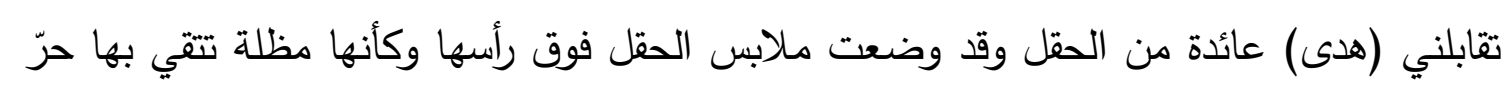

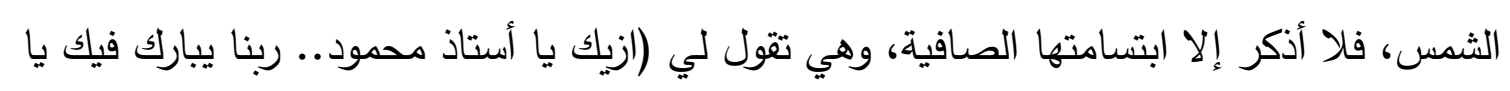

(1) " (رب) (1)

ومن خلال ما سبق يمكن القول إن تصوير الأديب لثخصياته هنا، تصوير وظيفي؛ فهو لم

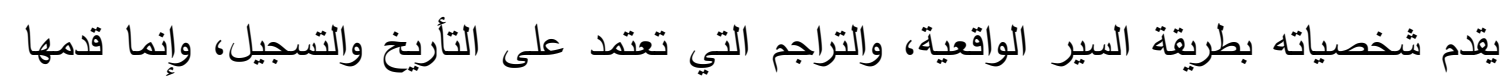

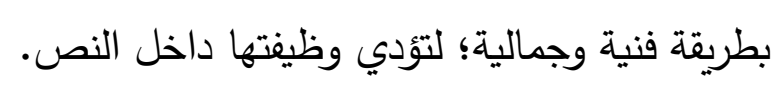

\section{الزمـــان}

الأصل في البناء الزمني للسيرة الذاتية، أن تلتزم الخط الزمني الدقيق في ترتيب الأحداث،

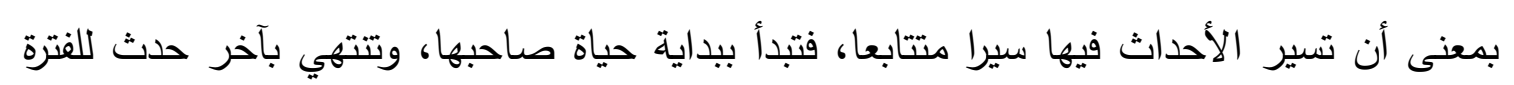
الزمنية التي يقف عندها الأديب.

وحينما ننظر إلى النص الذي بين أيدينا (ابن الريف، وابن الكاتب) نجد الأديب يجنح فيه

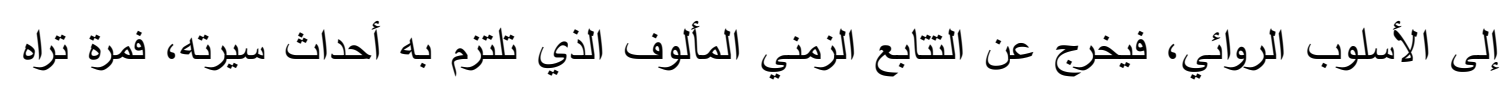




\section{تلداخل النوع الأببي بين السيرة الثاتية والرواية في أدب الدكتور عبد الحميد بلدان}

\section{د/محمل عبد المطلب محمل جودة \\ (ابن الريف وابن الكاتب) نعوذجا}

يتجاوز عن فترة زمنية معينة، ومرة تراه يتوقف عند فترة زمنية أخرى، ومرة يلجأ إلى الحذف (') والإسقاط وغير ذلك مما يفعله الروائيون من وسائل الخروج على المألوف، بقصد جذب القارئ، وكسر الرتابة، وذلك من منطلق الإحساس بالزمن والتأثز به والتقاعل معه، ومن ثم يأخذ الزمن هنا- شكلا من أشكال الرواية.

وتستطيع أن تلمح ذلك في استرجاعه وعودته إلى الوراء، في قوله: " وأذكر كيف كان الخوف يتملكني في ليالي الشتاء، عندما يقسو السحاب علينا، فيفرغ أثقاله على مباني قريتنا الهزيلة، وكيف لم يقو سقف بيتا الضعيف على حفظ الماء، فبتنا ليلتنا وقد رافقتا أوعية الطعام التي صفقناها كي تحتفظ بالماء النازل من السقف، مشوبا بالحمرة، من أثر الدخان الذي تشربه السقف، ولا أدري كيف قز إلى ذهني قول الله تعالى (فخرّ عليهم السقف من فوقهم) وكنت وقتها أحفظ في سورة (النحل) فأتخيل بعقلي الطفولي أن الآية نزلت في هذا المشهد الذي نحن فيه،

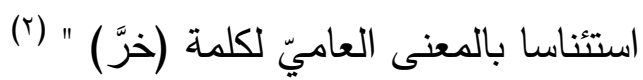

فالسيرة وإن كانت تقوم على الاسترجاع (ّ) والتذكر في الأساس، لكن صورة الاسترجاع الزمنية -هنا - صورة روائية بكل ما تعنيه الكلمة، من الإحساس بالزمن والإبداع في تشكيل صورته، والتخيل في رسم عناصره، فحديثه عن (ليالي الثتاء) ليس مجرد حديث عن زمن مجرد أو زمن سيري، بل هو حديث عن الانفعال الذي يتركه الزمن في نفس الأديب من مشاعر الخوف، والترقب، والألم - نتيجة هذا الشتاء القاسي- وليس مجرد تسجيل للزمن المجرد كما يحدث في السيرة.

وترى ذلك أيضا في قوله: " فكانت ذخيرتي التي ألجأ إليها حين أحاول البحث عن مناطق آمنة يغلب عليها الرضا والسعادة، أذكر فيها أيام الشتاء المظلمة، التي ما يعكر الصفو فيها إلا بعد الإنسان عمن يحبه، وعدم رؤيته أياما معدودات، يتجرعها العاشق ولا يكاد يسيغها، حتى يرى

(') يقصد به:" إسقاط فترة طويلة أو قصيرة من زمن القصة وعدم التطرق لما جرى فيها من وقائع وأحداث "

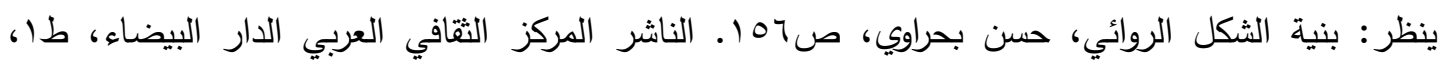
.0199 .

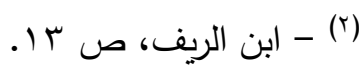

(ז)- وهو يعني: " الإثارة إلى حدث - بعد فواته- سابق للحظة القص التي نجد أنفسنا فيها " ينظر : مدخل إلى الى

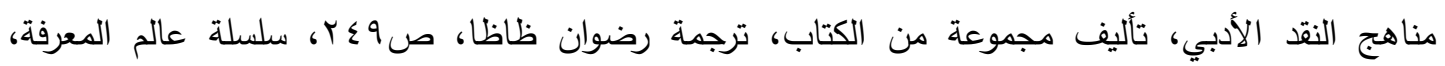

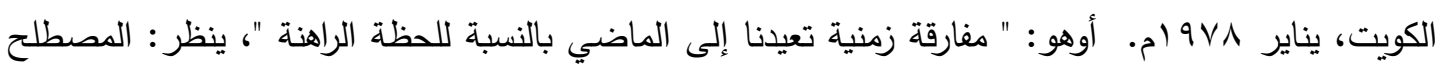

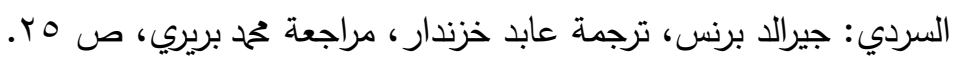


وجه من يحب، إن الريف هو كل ذللك، طالما كانت (هنا) أحد مفرداته الرائعة، فليت أمي كانت تعلم ذلك.

ثم أعود مرة أخرى فأذكر يوم نودي في القرية على حضور أول مناقثة لرسالة علمية

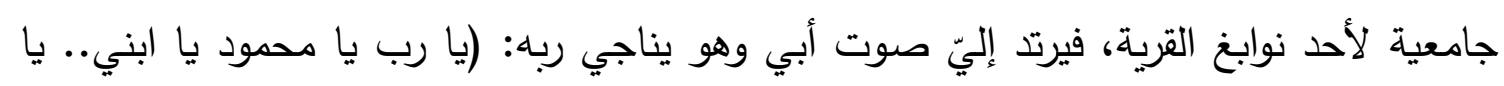

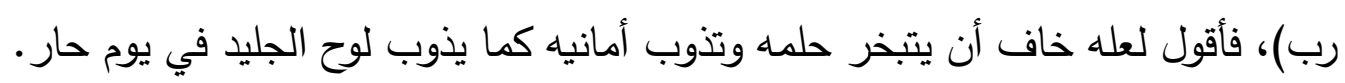

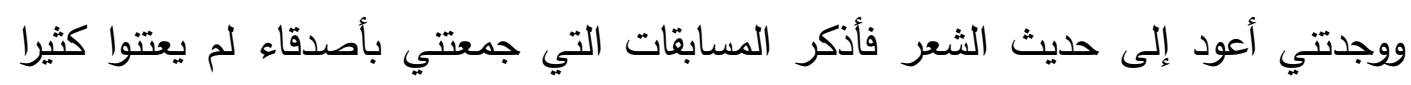

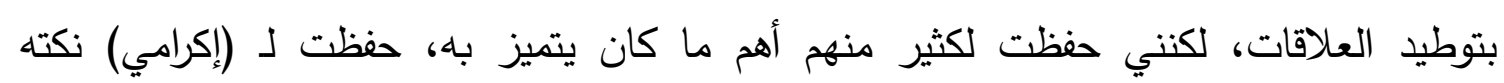

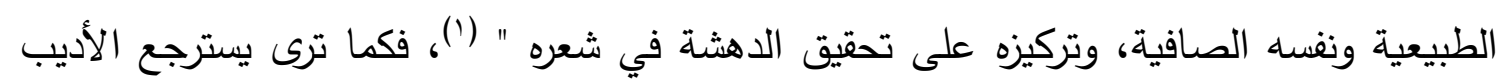

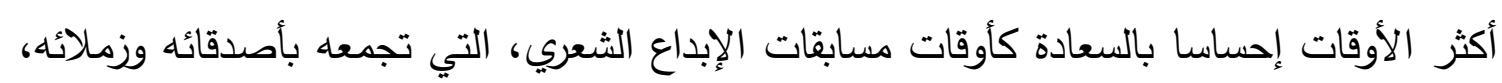

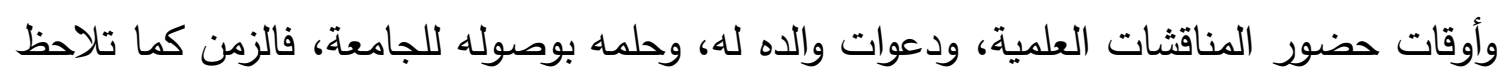
مبني على التفاعل والتأثر والتأثير والتوظيف.

كما كانت أكثر الأزمان التي يحتفي بها ويسترجعها، ويوظفها هي تلك الأوقات، التي يسعد

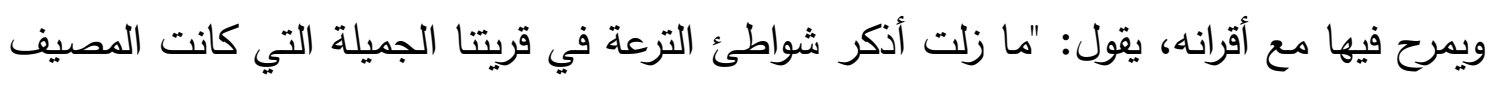

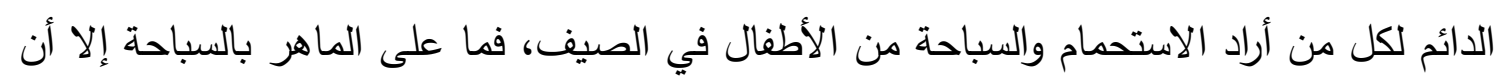

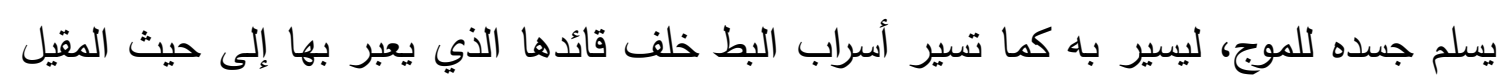

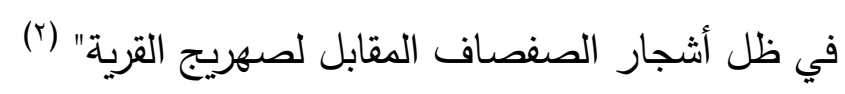

ولايزال الأديب يلح على التوظيف الدلالي للزمن: " لقد كنت طفلا حين كان أبي يردفني

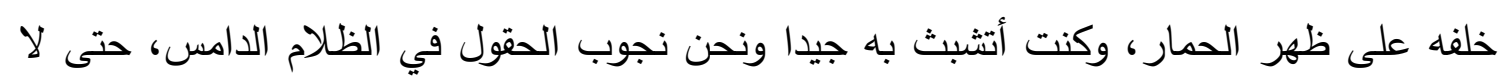

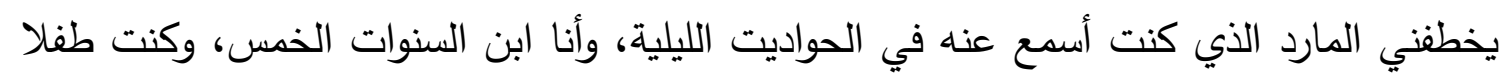

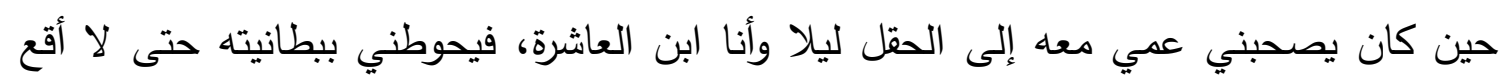

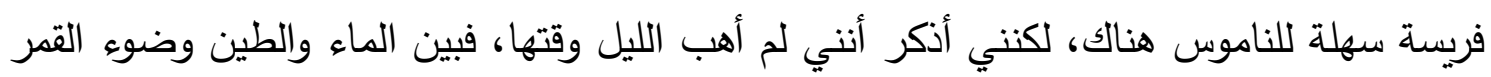

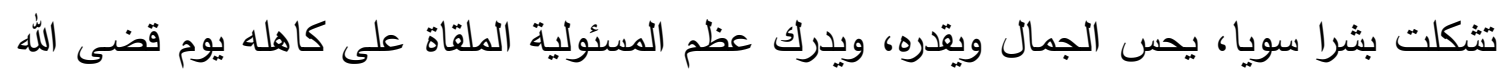
عليه أن أكون أكبر إخوة، ينظرون إليّ بعين المثال، ويتطلعون إلى محاكاة جميع ما أفعل " (")،

$$
\begin{aligned}
& \text { (')- ابن الريف، ص. • با }
\end{aligned}
$$

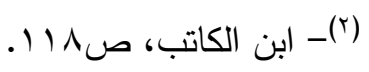

$$
\begin{aligned}
& \text { (r) }
\end{aligned}
$$




\section{تلداخل النوع الأببي بين السيرة الثاتية والرواية في أدب الدكتور عبد الحميد بلدان

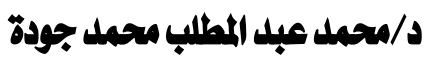

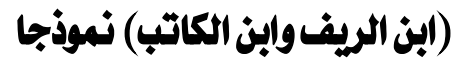

فاسترجاعه لزمان الطفولة، استرجاع له دلالته ووظيفته؛ إذ يشير من خلاله إلى تحمله للمسئولية وتصدره لها، وقد أخذ ذلك على عاتقه؛ نظرا لكونه أكبر إخوته واتخاذهم له قدوة في الأقوال والأفعال.

ولا يقتصر الزمان عنده على الاسترجاع والعودة للوراء، فبجانب هذا الاسترجاع الذي سيطر

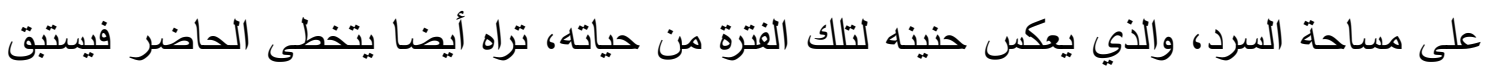

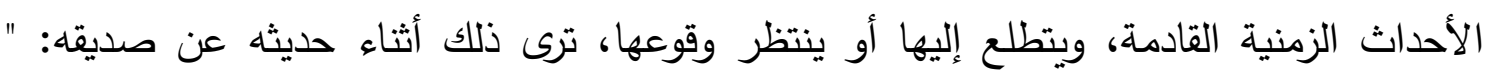

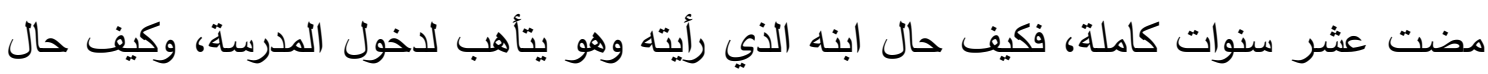

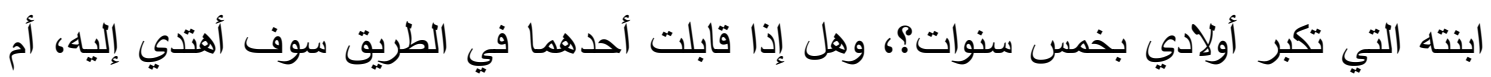

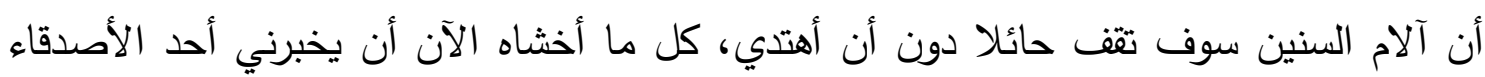

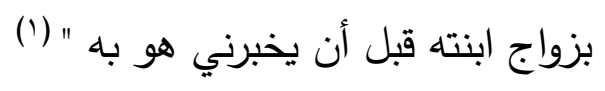

ترى ذلك أيضا في حواره مع زميله (أحمد) الذي تضمن حديثا عن المستقبل: " أتاني صوته عاليا هذه المرة، وكأنه يحاول أن يوقظني من بحر الذي ريله الكريات الذي غرقت فيه:

$$
\text { ـ أملي أن تكون معيدا في الكلية. }
$$

وبابتسامتها المعهودة طوقتني (هنا) بعبارتها الذهبية، لتدلل على أنها تتابع حوارنا:

• إن شاء الله ستكون معيدا " (ז)، فالحوار كما تلاحظ تخطى الزمن الحاضر ؛ لاستشراف المستقبل، المتعلق بمستقبل الأديب عبد الحميد بدران.

ومن ذلك أيضا وصيته لأولاده حول ما ينبغي أن يكونوا عليه الزمن القادم: " وأظنك ما زلت

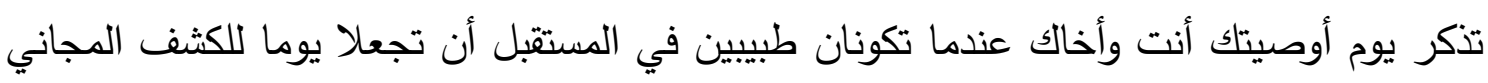

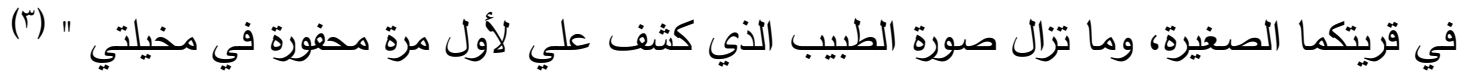

$$
\text { (') }
$$


ويأخذ الزمن عند الأديب-هنا- حس الرواية وطعمها من خلال التقنيات السردية التي

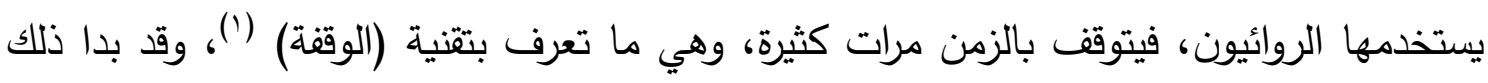

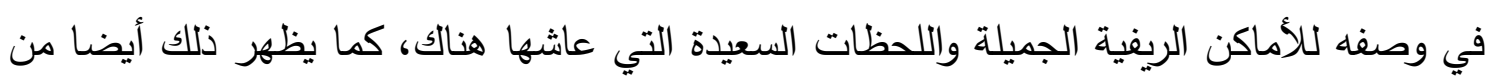

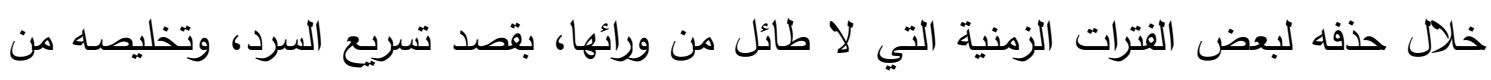

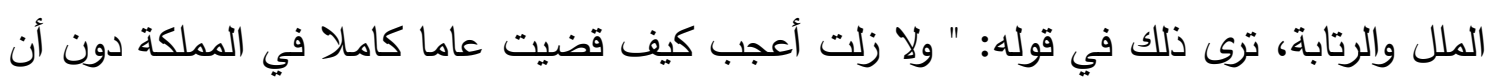

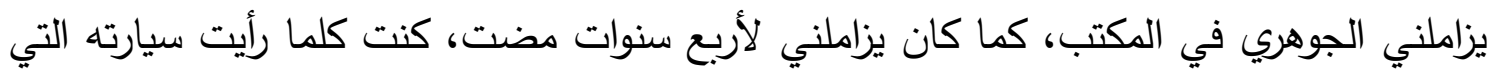

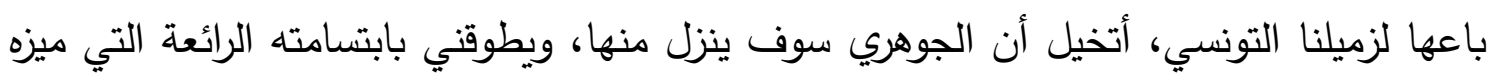

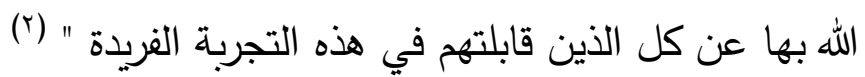

فالأديب - كما تلاحظ- صرح بمرور الأعوام (عاما كاملا.. لأربع سنوات مضت)، متجاوزا

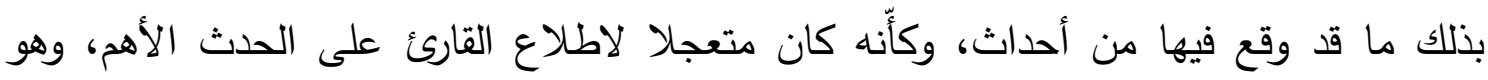
الكثف عن طبيعة هذه الثخصية (الجوهري) المبتسم، المتسامح، ومدى شوقه لذه له، وألمه لفراقه. وترى ذلك أيضا في قوله: " إنه أنفس كتاب صاحبني في حياتي الجامعية، لقد مضت عشر دان

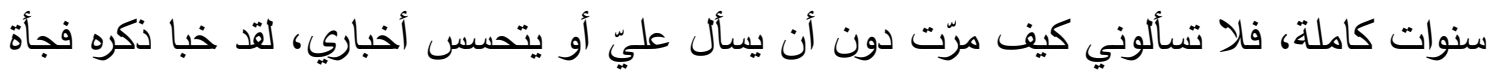

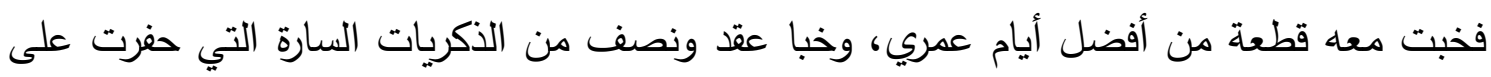

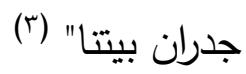

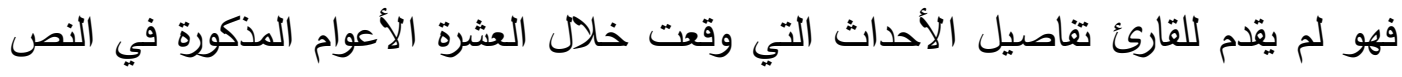

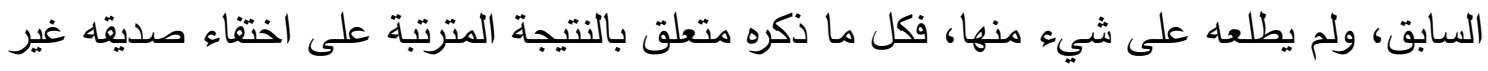

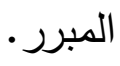

ويمكن القول إن الأديب-هنا- لم يقدم الزمن مجردا كما يقدم في السيرة، وإنما مزج في تقديمه

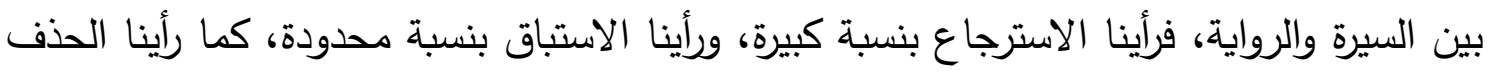

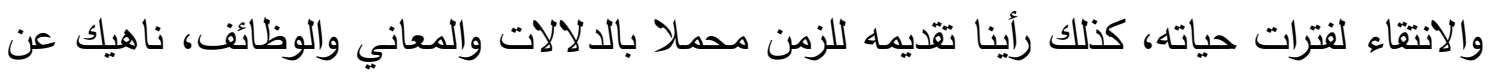

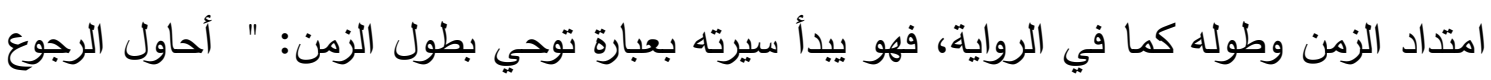

(1) ـ و: " تمثل الوقفة أقصى بطه يصيب السرد؛ إذ تتعطل حركته تماما، وتتوقف القصة عن التنامي، وتعلق

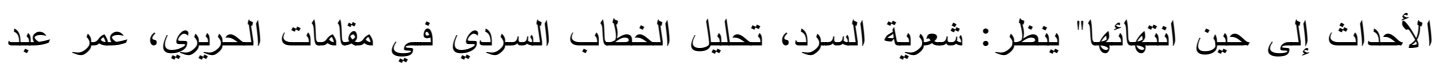

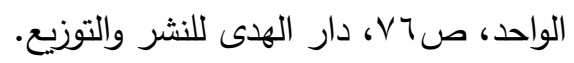

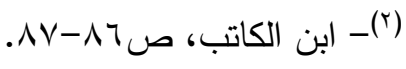

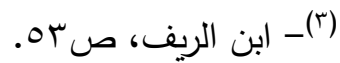




\section{تلاخل النوع الأدبي بين السيرة الداتية والرواية في أدب الدكتور عبد الحميد بلدان \\ د امحمد عبد المطلب محعل جودة \\ (ابن الريف وابن الكاتب) نموذجا}

بذاكرتي إلى الوراء حيث المدرسة الابتدائية ذات الطوابق الثلاثة، إلى حيث زملائي الذين نحتت صورهم بجميع تفاصيلها في مخيلتي، على الرغم من أننا لم نجتمع بعدها في أي فصل دراسي، لقد كان هذا المكان أول عهدي بالدنيا التي تمثل لي ما بعد الحارة التي ولدت فيها " ( ) فالنص كما ترى يعكس مساحة الزمن بين الزمن الفعلي الذي كتب فيه المؤلف سيرته، والزمن الذي وقعت فيه الأحداث ويبدأ بالميلاد والحارة والمدرسة الابتدائية... وتتتهي بلحظة سرد المؤلف لهذه الأحداث وهي مدة تزيد على الأربعين عاما. 
المكان

يعد المكان المسرح الذي تدور عليه حياة الثخصية وسيرتها فهو: " يؤدي دورا بالغ الأهمية في تثكيل السيرة الذاتية بوصفها فنا سرديا ينهض على استيليلاد مكان معين ومحدد له مرجعية

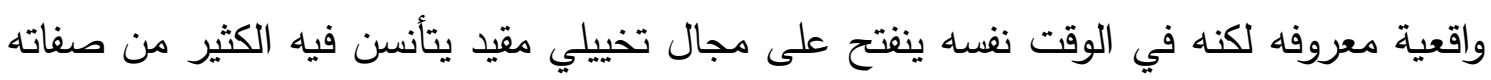

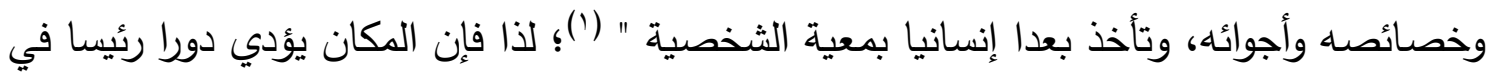

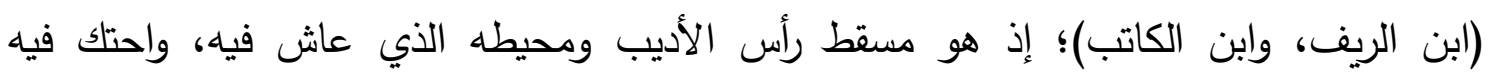

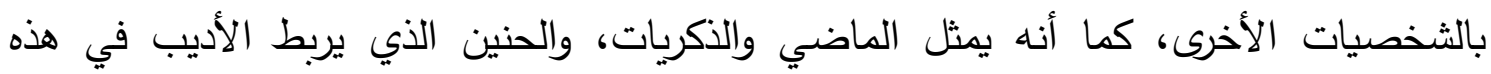
السيرة، بهذه البقعة وتلك الثخصيات والأحداث، التي تظهر من خلال هذا العنوان الدكاني الدال

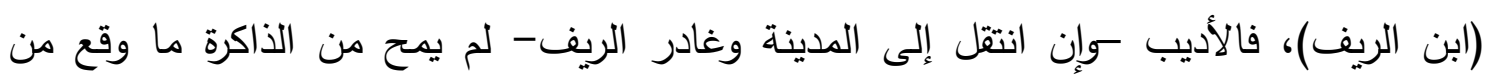

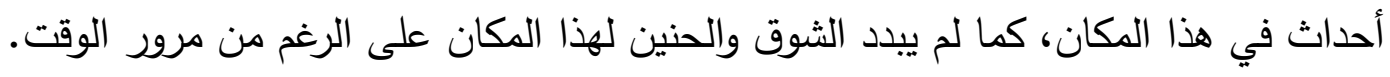

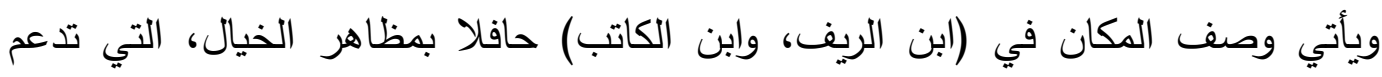
الميثاق الروائي؛ مما يؤدي إلى تراجع سلطة الجانب التسجيلي التاريخي لهذه السيرة، فالمكان

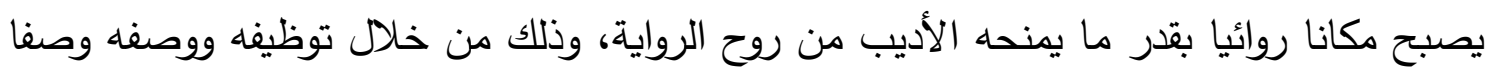
جماليا عن طريق اللغة الثاعرة التي تتبض بروح المكان وحضوره الفاعل، بمعنى أن يتحول

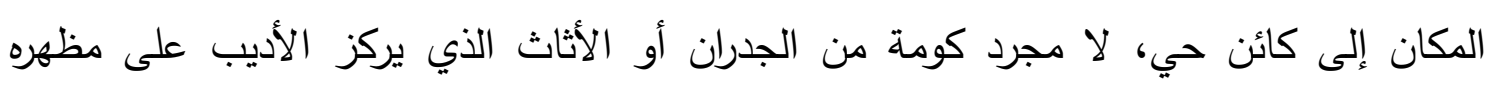
الخارجي دون سواه، أو الوصف التسجيلي الذي يفرغه من كل دلالة ومحتوى.

ومن ذلك وصفه للمكان - مسقط رأسه وملعب صباه - في ثوب روائي : " كان الفجر قد تنفس بعد أجازة العيد، ونفحت القرية مصابيح ربانية، أضاءت الكون شيئا فثيئا، وكانت العصافير

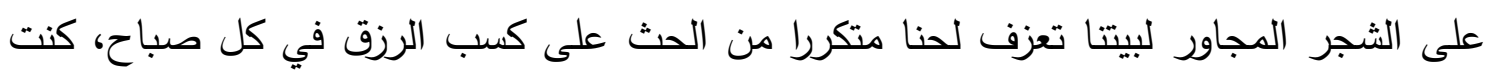

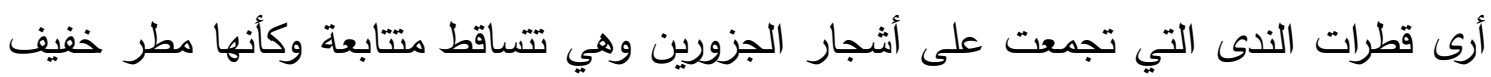

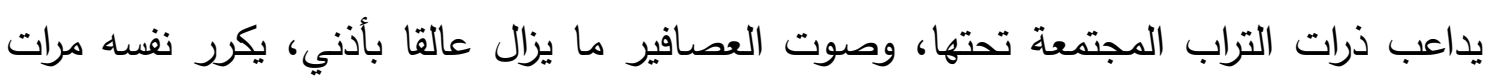

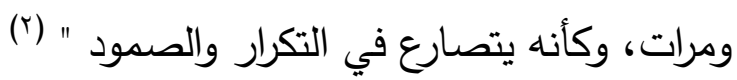

فحين تقرأ تجد نفسك أمام لوحة فنية، توضح هيئة المكان الذي نشأ فيه الأديب، وتبعث فيه الحياة والحركة، حتى تثعر وأنت تقرأ كأنك أمام شاعر رسام، لا لاميما وأنت تشعر بـ(تنفس الفجر )

(1)- التشكيل السير ذاتي، التجربة والكتابة، د ححمد صابر عبيد، ص و9، دار نينوي للدراسات والنشر والتوزيع،

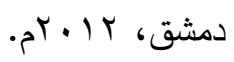

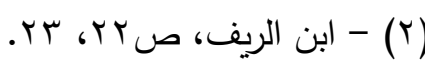




\section{تلداخل النوع الأببي بين السيرة الثاتية والرواية في أدب الدكتور عبد الحميد بلدان}

\section{د/معلد عبل المطلب محمل جودة}

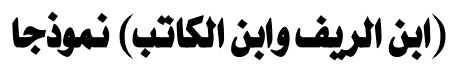

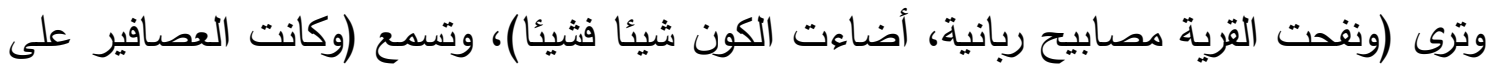

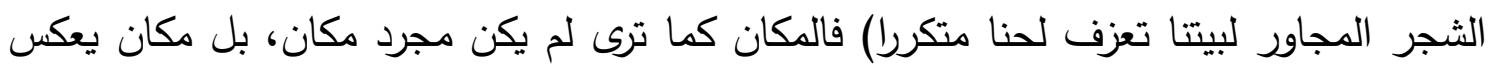
عشق الأديب لجمال الريف ومسقط الرأس البديع.

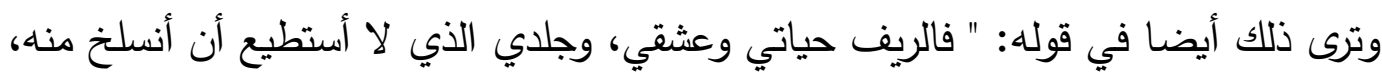
فيه لهوت ولعبت، وذاكرت وعشق، وسعدت وتنزهت، وراقبت زرعي وهو ينمو على سبحات

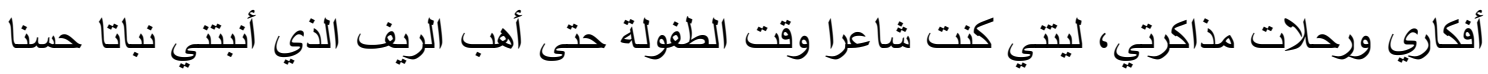

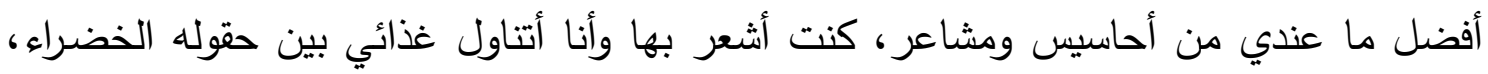

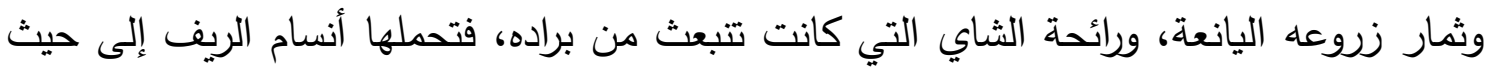

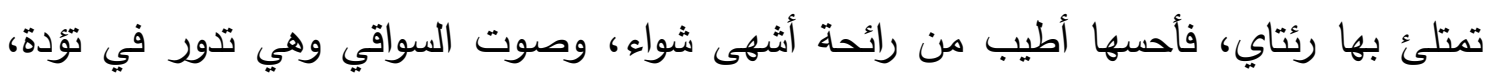

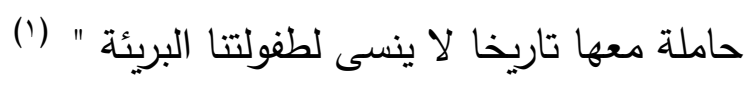

فوصفه المكان بهذا الأسلوب الراقي والأدبي، يعكس مدى الترابط بين الأديب وهذا المكان،

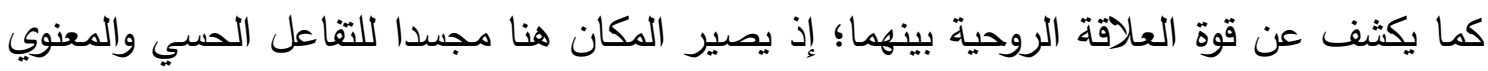

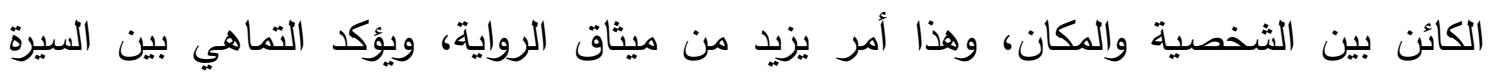
والرواية.

وحينما تحدث عن (المدرسة) لم يتحدث عنها بأنها مجرد مكان، بل دفعه حسه الروائي إلى : لصى

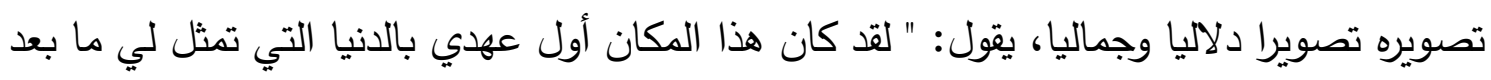

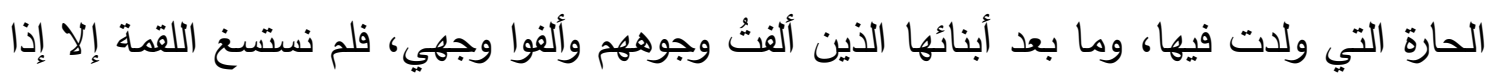

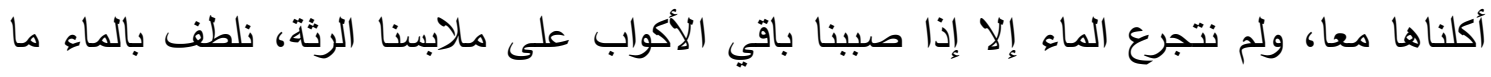
عسى أن تصنعه الثمس بأجسادنا الضعيفة.

كانت المدرسة الابتدائية شاهدا على أول اختلاط مشروع بين الطالب وزميله وزميلته،

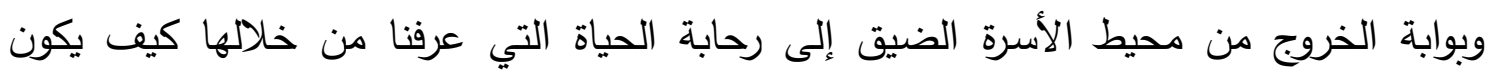

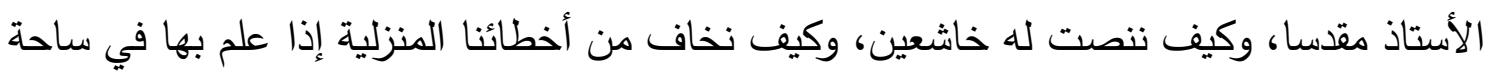

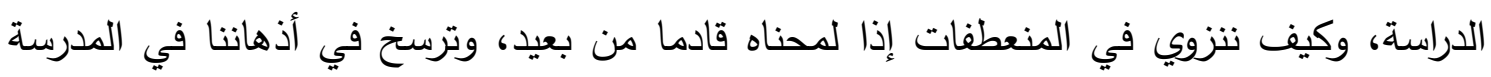

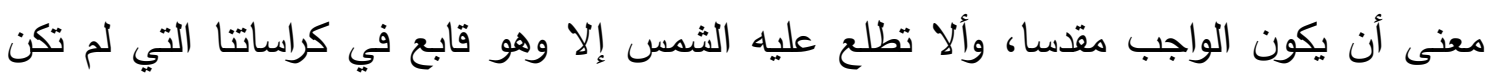

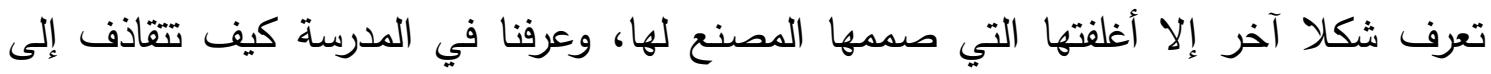
أذهاننا أسماء زملائنا مقرونة بصورهم وملابسهم وسماتهم وردود أفعالهم أمام مدرس اللغة العربية 
الذي كانوا يهابونه مهابة الأب " (')، فالمكان (المدرسة) هنا لم تكن مكانا لتسجيل الأحداث التي وقعت للأديب بطريقة السيرة، وإنما جاء ليؤدي وظيفة - على طريقة الرواية - وهي إبراز مكانة المدرسة ودورها الإيجابي في حياته وحياة زملائه.

وفي معرض مقارنته بين بيته الذي كان، وبيته الحاضر ، يقول: " لقد عدّلنا من هيئة

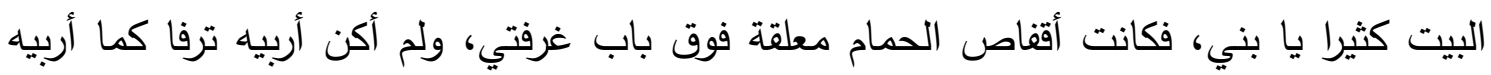

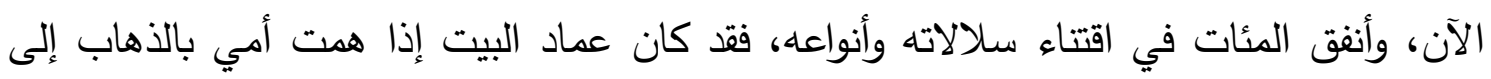

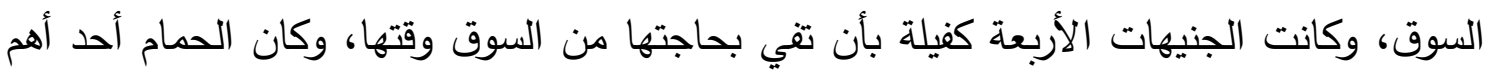

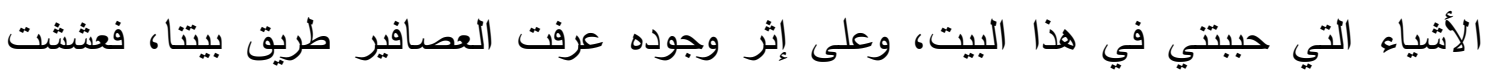

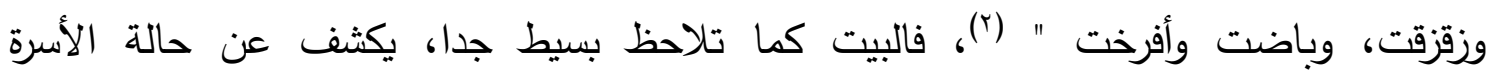

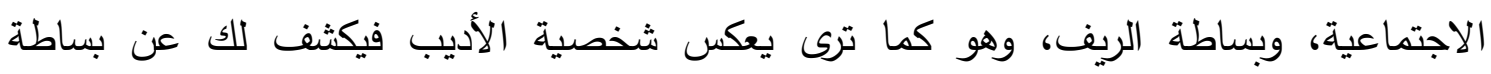
شخصيته ورهافة مشاعره؛ إذ المكان امتداد لصاحبه، ومن ثم فرسم المكان رسم لصاحبه وتكبه وتعبير عنـه.

وتبدو جماليات المكان المغلفة بروح الإحساس الروائي، أثناء حديثه لابنه عن تحمله

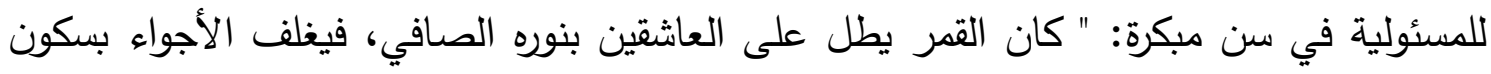

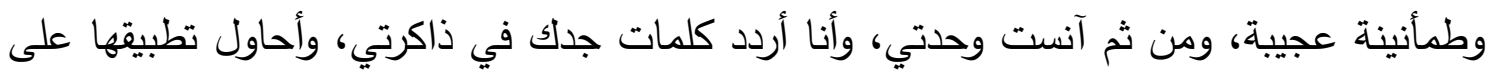

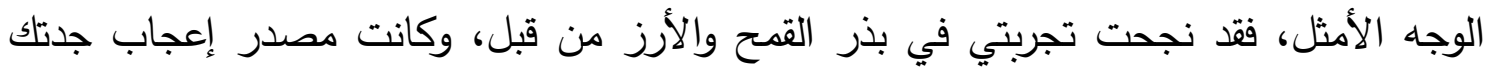

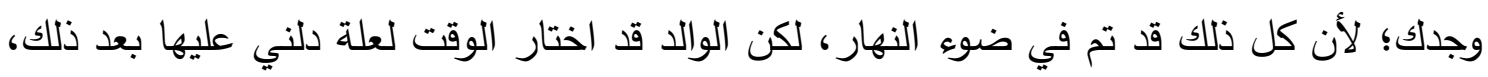

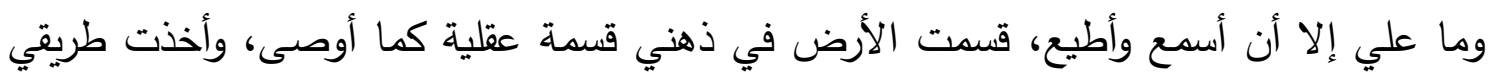

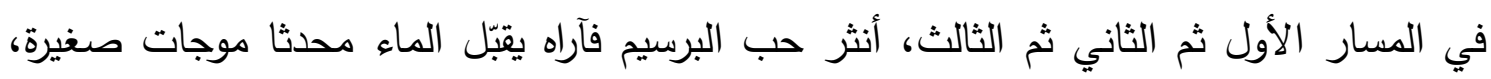

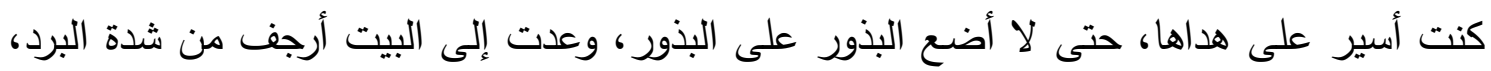

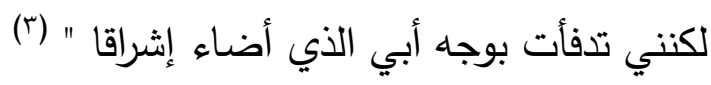
فأنت ترى هنا صورة شعرية للمكان، يغلب عليها الطابع الرومانسي الذي تحسه في قوله:

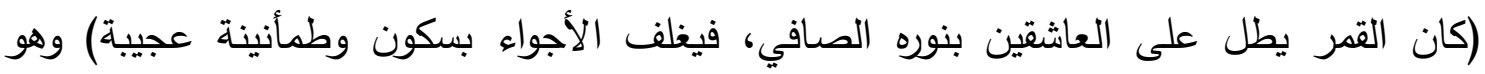
أسلوب لا يتوافر إلا لمن لله حس شاعري، يمزج من خلالها بين الواقع والخيال.

$$
\begin{aligned}
& \text { (') - ابن الريف، ص1ا7،0. }
\end{aligned}
$$

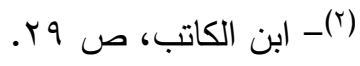

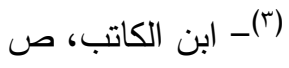




\section{تلداخل النوع الأببي بين السيرة الثاتية والرواية في أدب الدكتور عبد الحميد بلدان

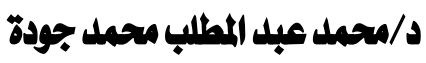

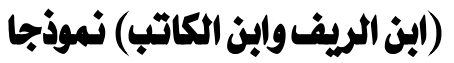

وتراه يعود بذاكرته لاسترجاع ما ترسخ في ذاكرته من تلك الأماكن : " وأذكر التتزه في

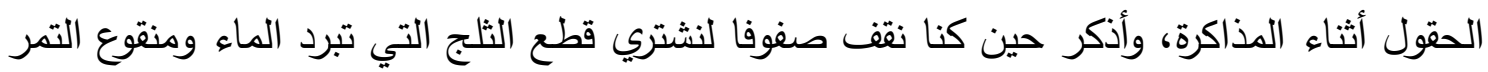
والعرقسوس، وأذكر أطباق المأكولات الثعبية المتبادلة بين الجيران قبل مغيب الثمس بلحظات،

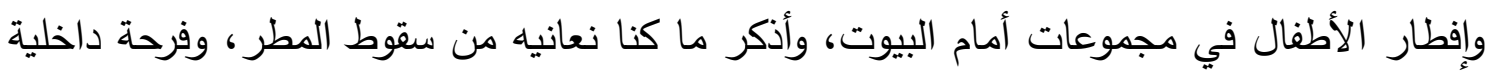

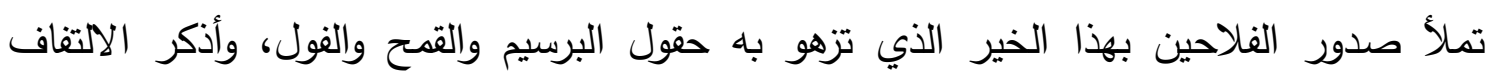
المشروع حول الموقد الفخاري من أجل الحصول على دفقة من دفء، يغيث البدن فئ في ليالي الثتاء

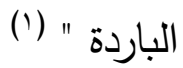

" وهناك على بعد أمتار، وحين يسند ظهره إلى الثجرة القريبة من غرفته تخرج الحكايا الطيبة

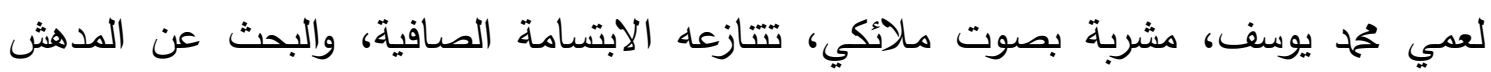

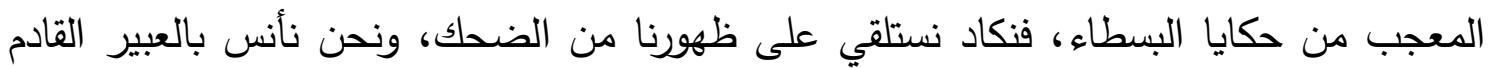

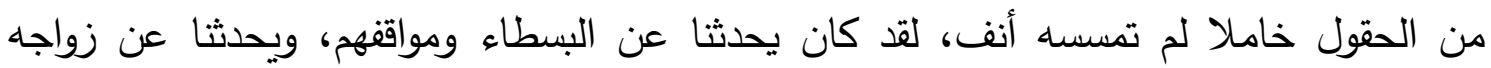

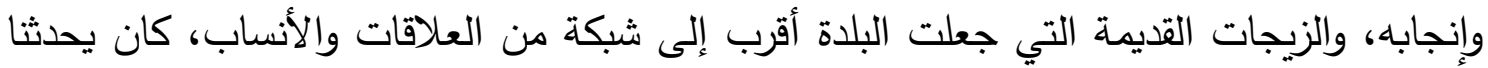

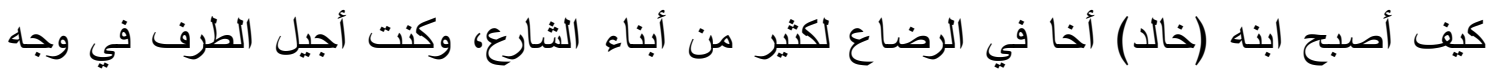

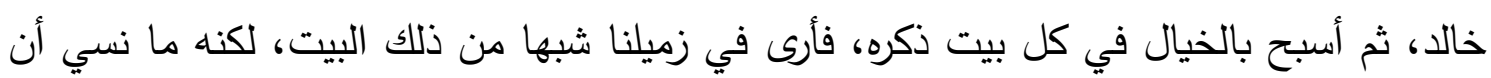

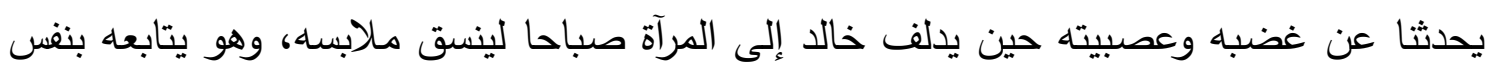

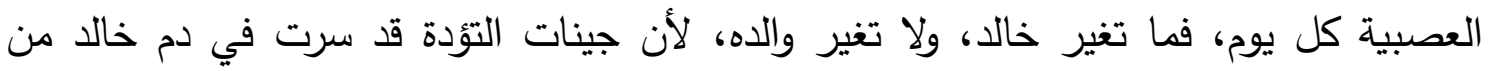

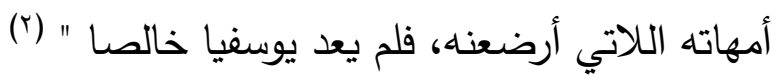

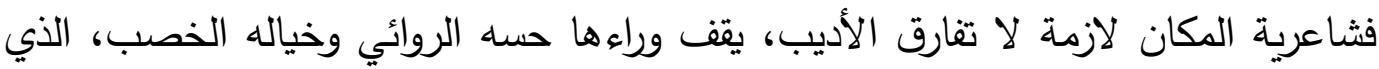

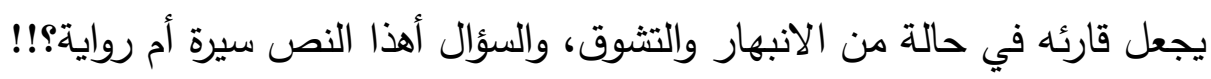

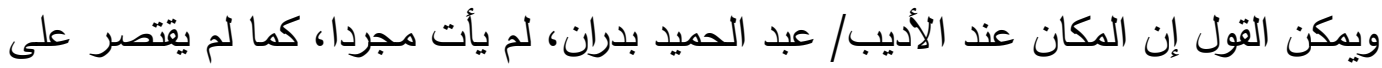
الخبر المجرد، الذي يذكره بمجرد مشاهدته لأول مرة، بل يذكره لأنه عاش فيه وتأثر بهاه، وتفاعل معه، ومن ثم فتصويره للمكان - بالرغم من حقيقته- تصوير يقوم على مزج الواقع بالخيال، والتحوير ، والتوظيف الذي يقوم عليه الفن الروائي.

$$
\begin{aligned}
& \text { (') - ابن الكاتب، ص بات. } \\
& \text { (r) }
\end{aligned}
$$




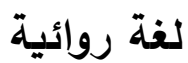

إن اللغة في السيرة تختلف عن اللغة في الرواية، ففي الغالب عندما يكون الكاتب كاتبا للسيرة

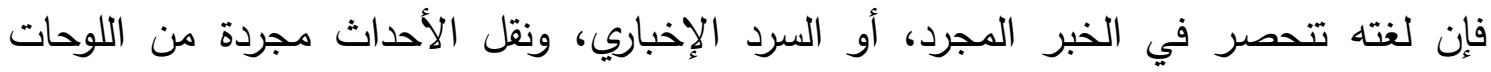
الإبداعية، والتغيير والتحوير، والصور البلاغية، على العكس تماما من لغة الرواية فالكاتب حينما

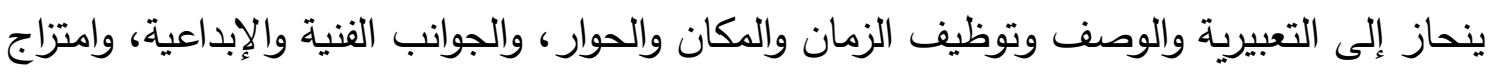

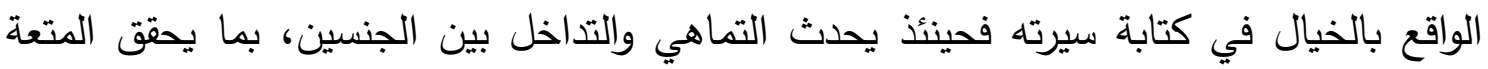

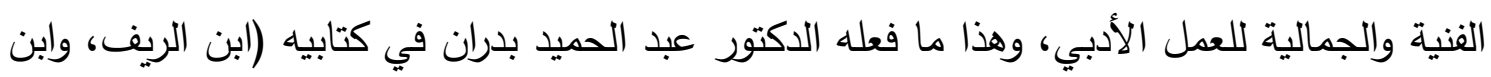

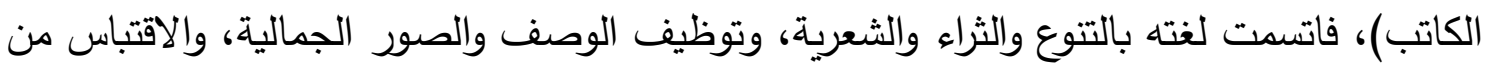
القرآن الكريم، والحضور الواضح لثعره الذي يقرضه في كل موقف وحدث.

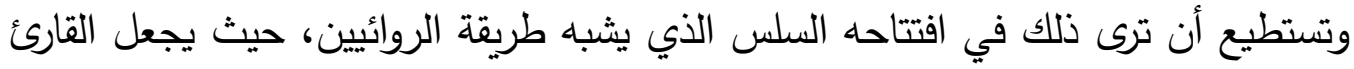

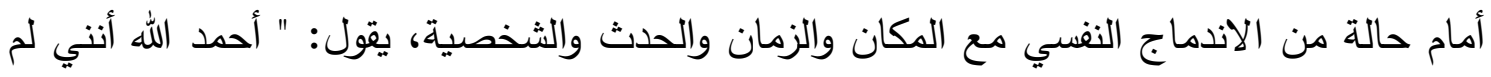
أكن أحد أبناء الطبقة المتوسطة، فربما لو كنت أحد أبنائها لما كنت حريصا ولى ولى الجد في تحصيل

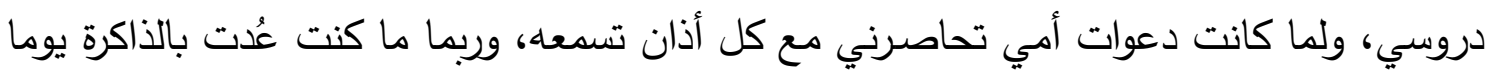

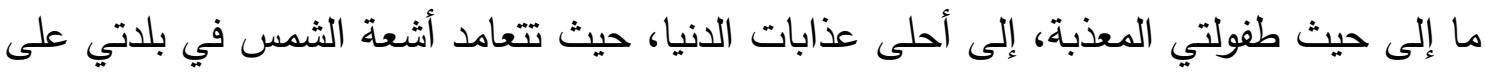

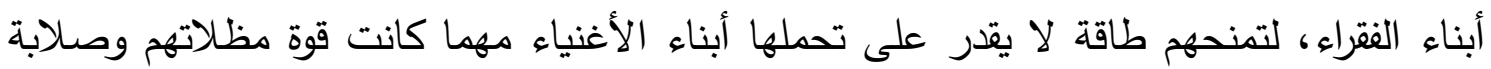

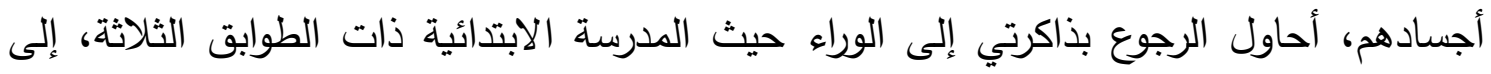

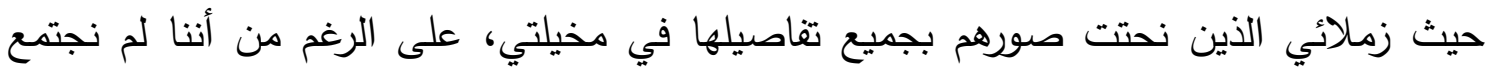

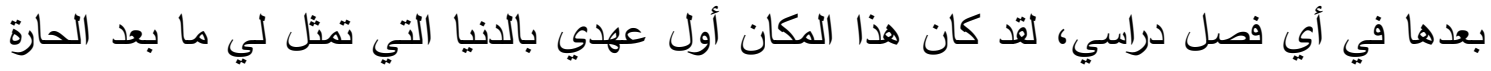

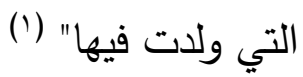

فالقارئ يتناول هذا العمل على أنه سيرة ذاتية، وسرد ذاتي، لكنه سرعان ما يجد نفسه أمام

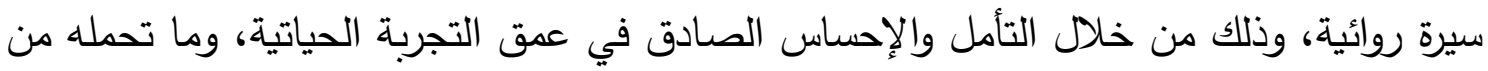
أسلوب قصصي مشوق، ومتدفق.

ومما ساعد على التماهي والتداخل بين السيرة والرواية لدى الدكتور عبد الحميد بدران هو

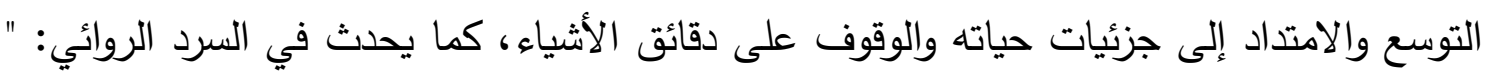

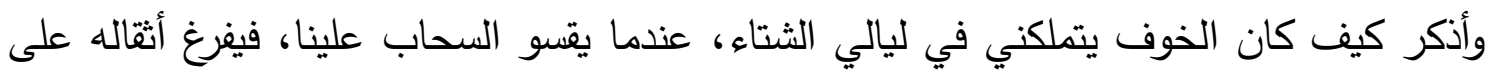




\section{تلاخل النوع الأدبي بين السيرة الداتية والرواية في أدب الدكتور عبد الحميد بلدان \\ د/محمل عبد المطلب محمل جودة \\ (ابن الريف وابن الكاتب) نعوذجا}

مباني قريتنا الهزيلة، وكيف لم يقو سقف بيتنا الضعيف على حفظ الماء، فبتنا ليلتنا وقد رافقتنا

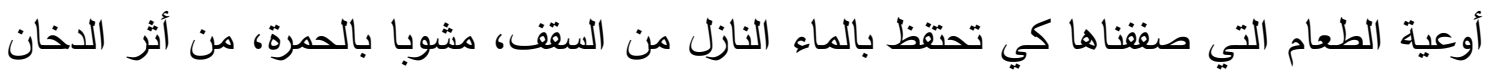
الذي تشربه السقف، ولا أدري كيف قفز إلى ذهني قول الله تعالى (فخرّ عليهخ السقف من فوقهم)

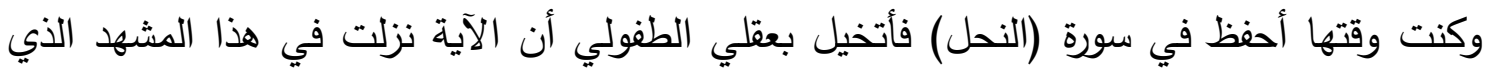

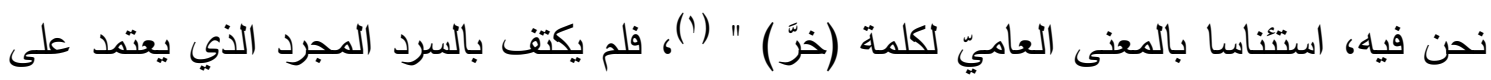

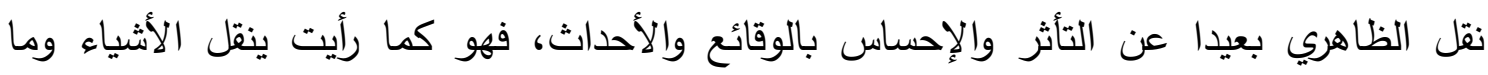
يرافقها بدقة وتفصيل، والأمثلة على ذلك كثيرة ومتعددة.

امتازت لغته أيضا بالثعرية فابتعد عن الاستخدام المباشر للألفاظ، فولد الصور الفنية، التي

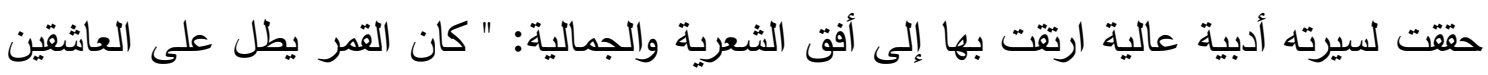

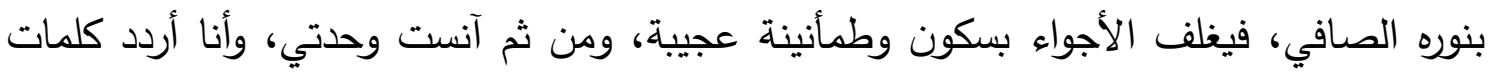

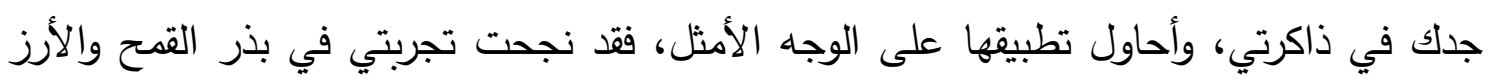

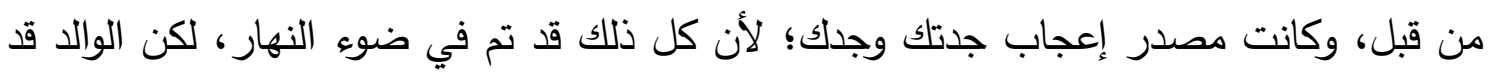

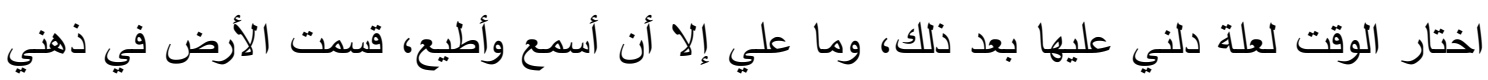

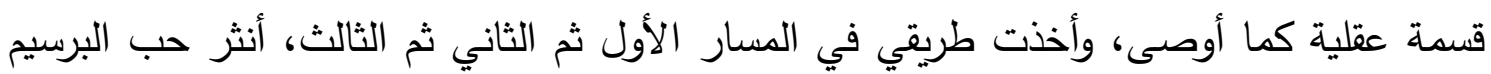

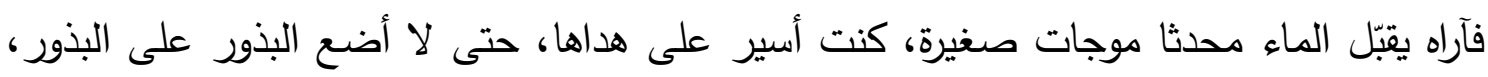

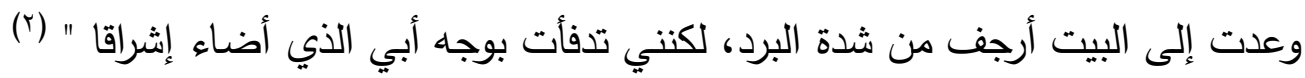
ويقول: " ولم يكن ينقصك إلا أن تصف الطريق الذي كنا نسير فيه، وقد اصطف الثجر من

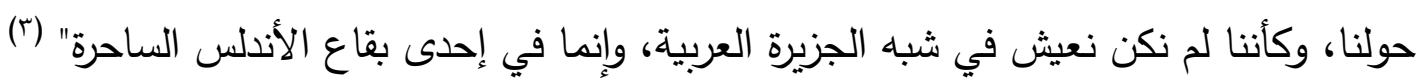
ويقول: " وطعم السعادة التي كنت أشعر بها كلما شمت رائحة الريف، أو سمعت همس

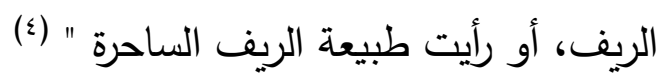

ويتحدث عن مشاعره وأحاسيسه تجاه الريف الذي يحن إليه باستمرار : " كنت أشعر بها وأنا

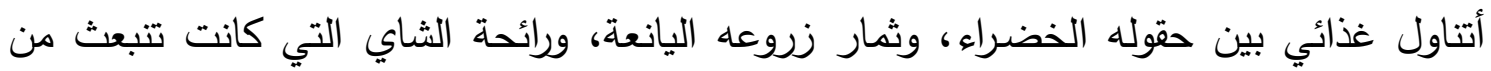

$$
\begin{aligned}
& \text { (') - ابن الريف، ص سا (ال. }
\end{aligned}
$$

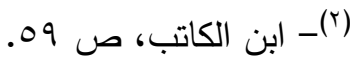

$$
\begin{aligned}
& \text { (ז) }
\end{aligned}
$$

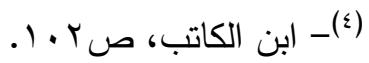


براده، فتحملها أنسام الريف إلى حيث تمتلئ بها رئتاي، فأحسها أطيب من رائحة أشهى شواء،

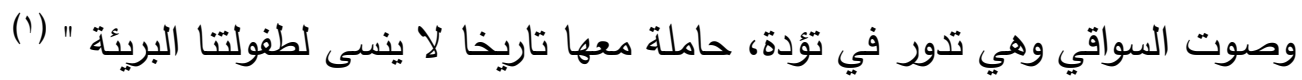
ومن ذلك تصويره لمشهد الوداع لإحدى زميلات الدراسة وصديقات الطفولة في القرية: "

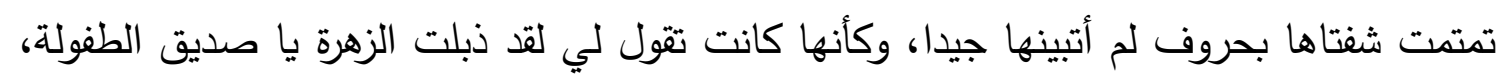
بعد أن وضعت لقاح الزهر في كل حقل عملت فيه من حقول القرية. هذه هي رائحة الريف الصافية التي يشعر بها كل من كان له قلب، هذه هي الرائحة التي

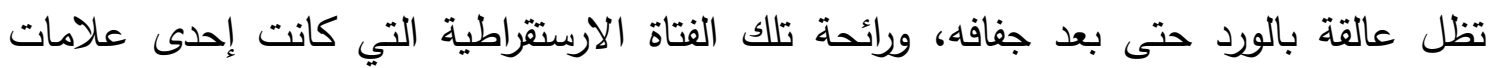

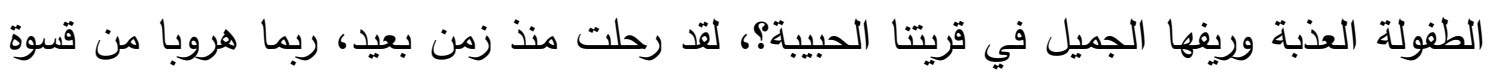

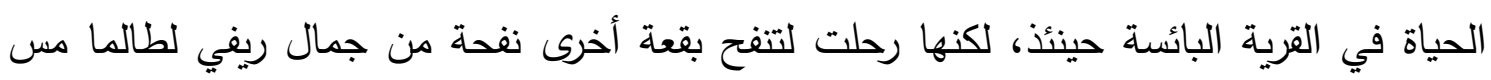

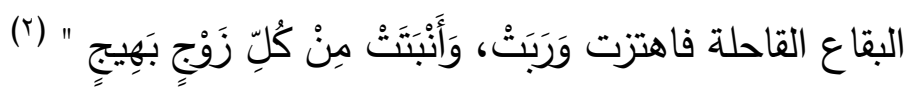
فأنت تشعر حين تقرأ وكأنك أمام قطع أدبية، محلاة بالصورة القرآنية الخالدة، وهي كثيرة في

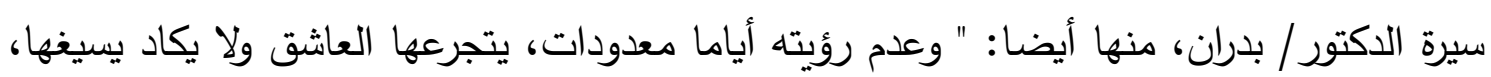

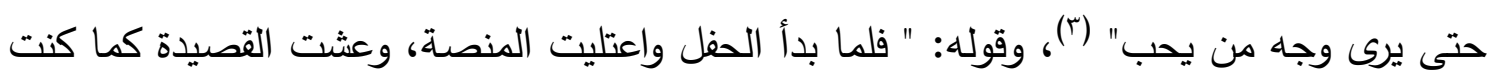

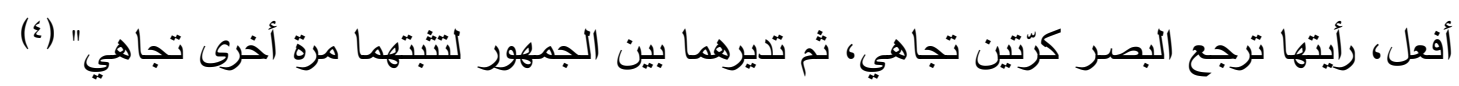

ويمكن القول إن لغة عبد الحميد بدران لها حضورها وملامحها، حيث صب سيرته الذاتية في القالب الروائي، الذي يعتمد على السرد والتصوير ، وإيجاد الترابط والاتساق الفني بين الأحداث،

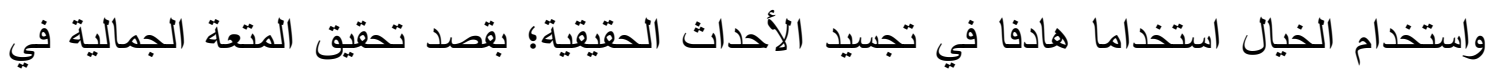

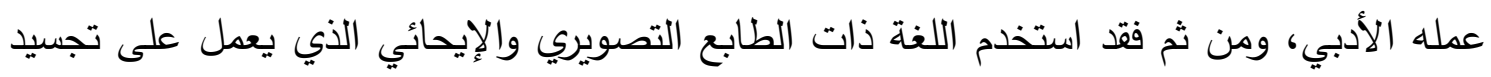
الأحداث ورسمها في حسن صياغة وجمال أسلوب حيث طغى الحس الروائي والفني والجمالي - في

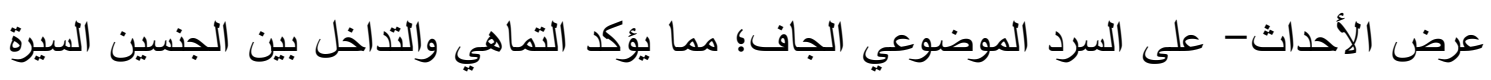
الذاتية والرواية.

$$
\begin{aligned}
& \text { (')- ابن الريف، ص919. }
\end{aligned}
$$

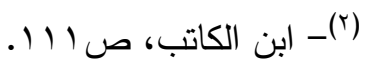

$$
\begin{aligned}
& \text { (r) }
\end{aligned}
$$

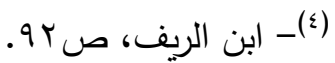




\section{تلداخل النوع الأببي بين السيرة الثاتية والرواية في أدب الدكتور عبد الحميد بلدان \\ د/معل عبد المطلب محمل جودة

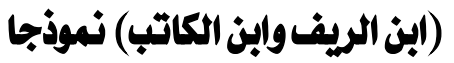

\section{الخاتمة}

هكذا استطاع الأديب عبد الحميد بدران أن يعرض حياته الخاصة وتجاربه الذاتية، بطريقة درامية، ذات أبعاد ودلالات، فرصدت لنا دور الزمان والمكان، والأحداث التي أسهمت في بناء شخصيته، وتكوين عالمه النفسي، ورسمت لنا خيوطا متعددة من مراحل حياته، تثير في معظمها إلى ارتباطه واعتزازه بالريف وشوقه إليه، فجاءت سيرته الذاتية في حلة الرواية، ولعل هذا التداخل هو ما يثير إلى الصفاء، والدفء، والاطمئنان الذي يجده الأديب في الريف وفي ممارسة الكئه الكتابة، وفي ختام هذا البحث يمكن أن أذكر بعض النتائج التي توصلت إليها، وهي:

1- كثفت هذه الدراسة عن مدى التقارب الأجناسي بين السيرة الذاتية والرواية، وأن

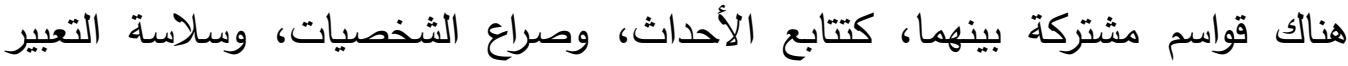

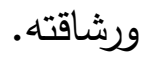

ז- أظهرت الدراسة أن القالب الروائي هو الأرقى أو الشكل المناسب لترجمة حياة

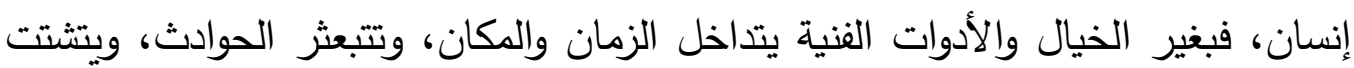

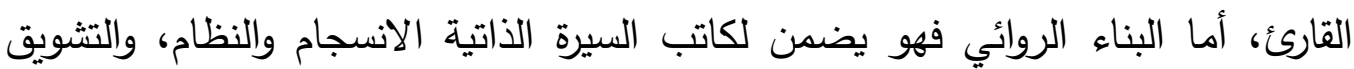

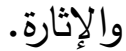

r- أشارت الدراسة إلى إبداع الأديب الذي أفاد أن التداخل -هنا- كان تداخل تجاور ،

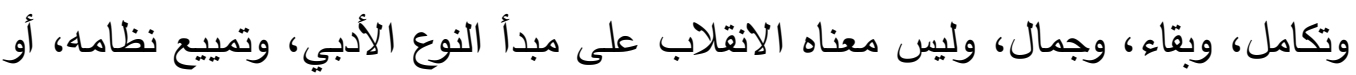

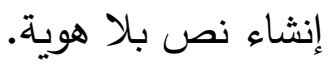
؟-استطاع الأديب أن يوظف تقدئنيات الرواية بمهارة، فالتزمت سيرته بنمط فني وأسلوب سردي يغري القارئ بالاستمرار في قراءتها. ه-كثفت الدراسة عن موهبة الأديب وقدرته على الحبكة والقص والتشويق، وإثارة القارئ وإغرائه، وذلك بما يملكه من خيال خصب، ولغة اقتربت من الثعر في مواطن كثيرة، وخاصة الصور الإيحائية. 


$$
\text { فهرس المصدادر والمراجع }
$$

أولا: المصادر:

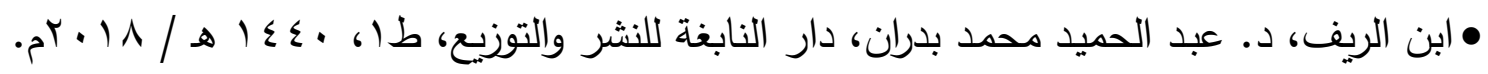

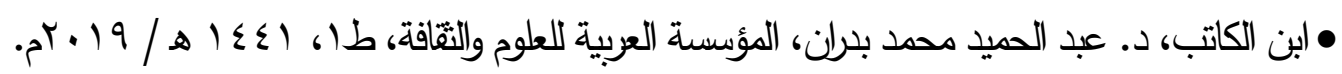

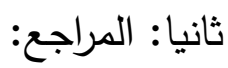

• اتجاهات القصة المصرية القصيرة، د. سيد حامد النساج، صبات آس، مكتبة غريب، 911 ام.

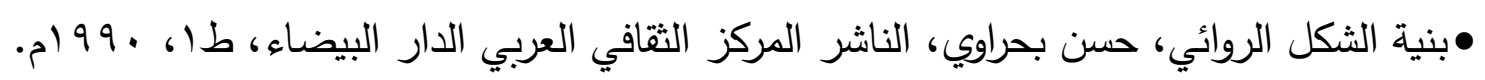

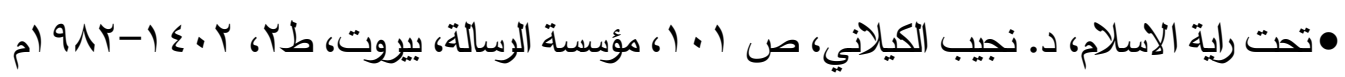

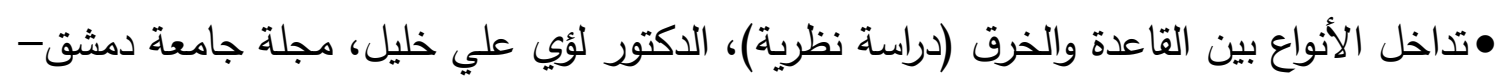

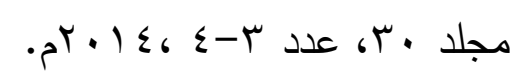

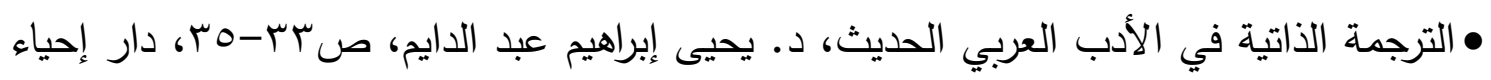

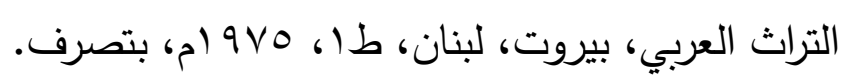

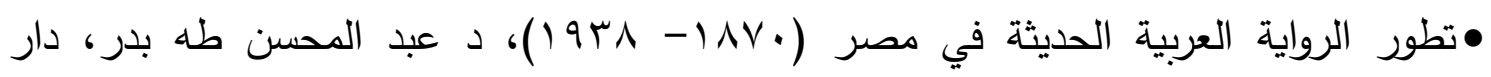

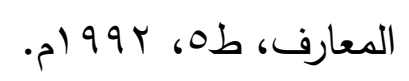

• التفاعل في الأجناس الأدبية (مشروع قراءة لنماذج من الأجناس النثرية القديمة من القرنين

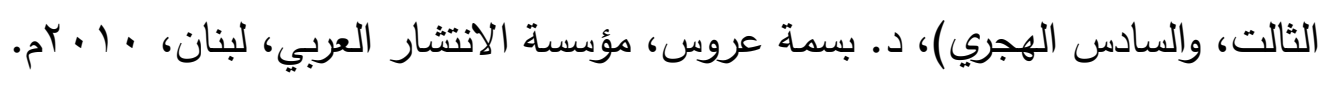

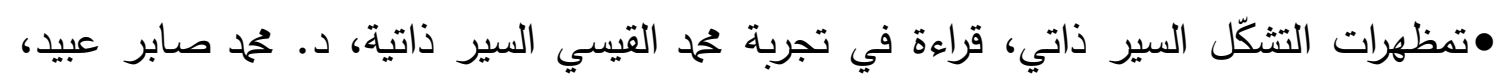
منشورات اتحاد الكتاب العرب، دمشق، 0 . • بام.

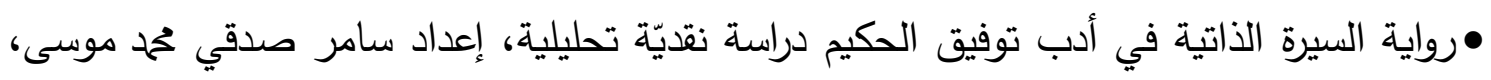

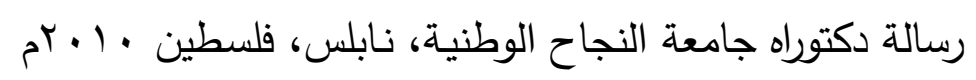

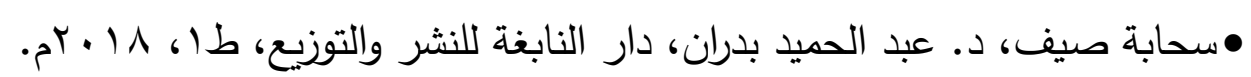

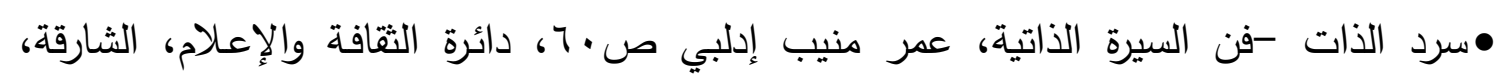

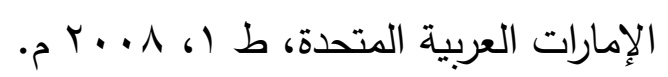

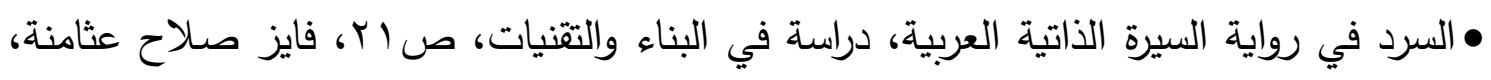

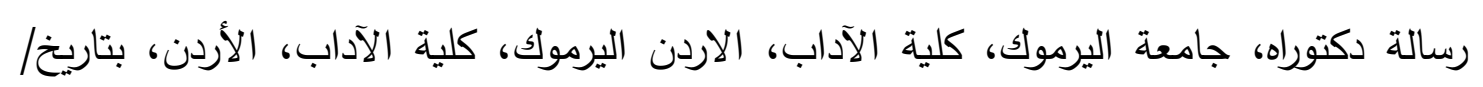

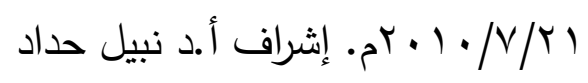

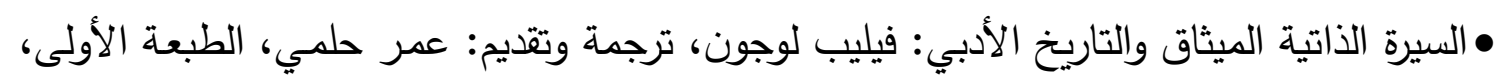

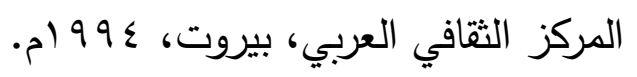




\section{تلاخل النوع الأدبي بين السيرة الداتية والرواية في أدب الدكتور عبد الحميد بلدان \\ د/محمل عبد المطلب محعل جودة

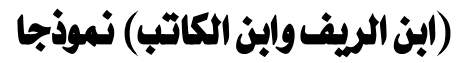

• السيرة الذاتية النسائية في الأدب العربي المعاصر، أمل التميمي، ص ا9 (ا، المركز الثقافي العربي، المغرب، طا، 0 ـ . بام.

• السيرة الذاتية في الأدب العربي الحديث (رؤية نقدية)، د. شعبان عبد الحكيم خحد، مؤسسة الوراق

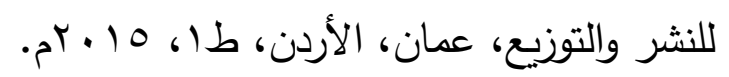

• السيرة الذاتية في الأدب العربي، تهاني عبد الفتاح شاكر، صب؟، المؤسسة العربية للدراسات والنشر ، بيروت، طام، ب + . بrم.

• سيرة جبرا الذاتية في (البئر الأولى وشارع الأميرات) خليل شكري هياس، من منشورات اتحاد

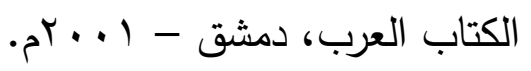

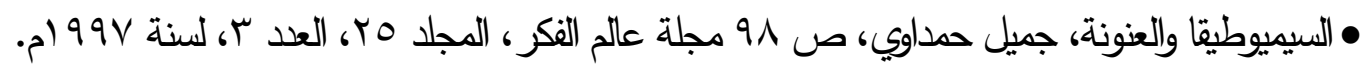
•شعرية السرد، تحليل الخطاب السردي في مقامات الحريري، عمر عبد الواحد، دار الهدى للنشر والتوزيح.

• عندما تتكلم الذات، السيرة الذاتية في الأدب العربي الحديث، د. محم الباردي، منشورات اتحاد

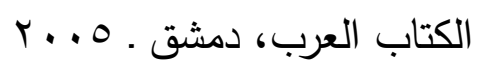

• فن السيرة بين الذاتية والغيرية في ضوء النقد الأدبي، د. عبد اللطيف الحديدي، دار السعادة للطباعة، القاهرة، طام، 997 ام بتصرف.

• فن السيرة، دكتور إحسان عباس، ص ب • (، دار صادر، بيروت - لبنان، طاه، 999 (م. • في نظرية الرواية بحث في تثنيات السرد، د عبد الملك مرتاض، ص | (ا، عالم المعرفة، الكويت، 991 (م. • مدخل إلى مناهج النقد الأدبي، تأليف مجموعة من الكتاب، ترجمة رضوان ظاظا، سلسلة عالم المعرفة، الكويت، يناير $9 \vee \wedge$ أم.

• المصطلح السردي: جيرالد برنس، ترجمة عابد خزندار، مراجعة خحم بريري، المجلس الأعلى

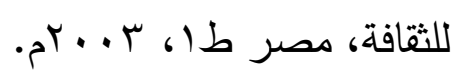

• معجم التعريفات (قاموس المصطلحات وتعريفات عمم الفقه واللغة والفلسفة والمنطق والتصوف والنحو والصرف والعروض والبلاغة) علي بن تحم السيد الشريف الجرجاني، ت/ تحمد صديق المنشاوي، دار الفضيلة، الإمارات، دبي، د ت.

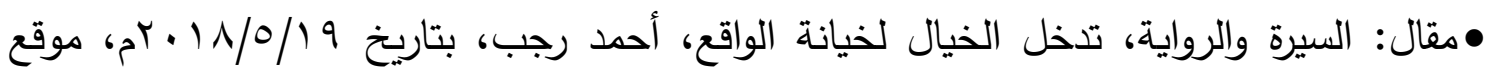
https:middle-est-online.com •وهج السرد (مقاربات في الخطاب السردي السعودي)، صه9،، حسين المناصرة، إربد، عالم

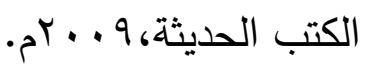


المحتويات

مقدمة...................................................................

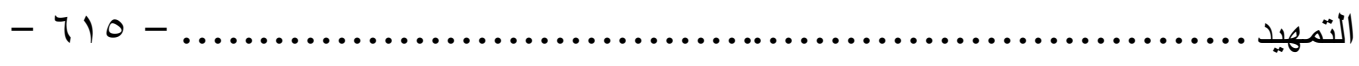

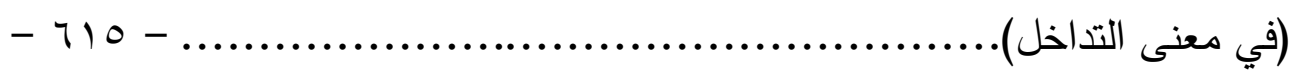

المبحث الأول: عناصر السيرة الذاتية...............................................

ميثاق السيرة.................................................................

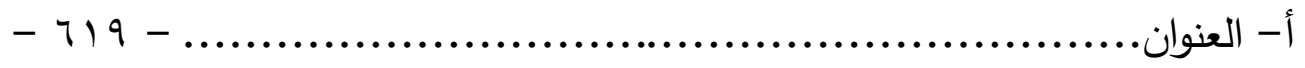

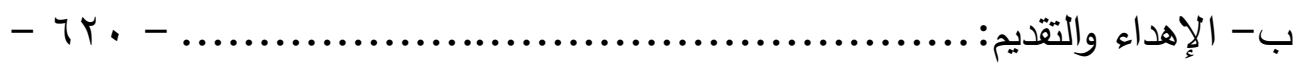

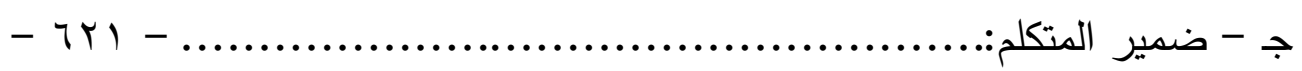

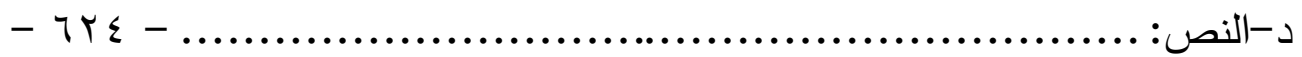

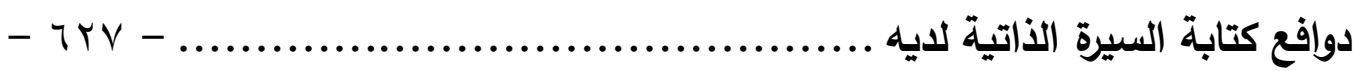

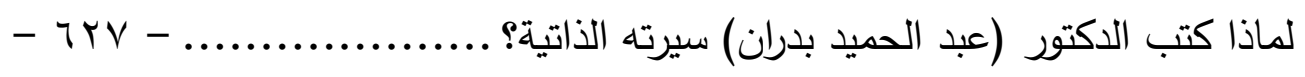

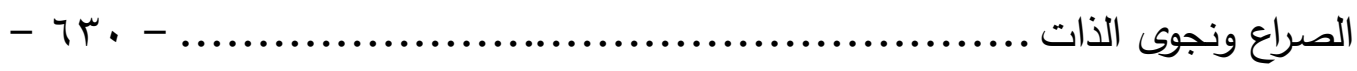

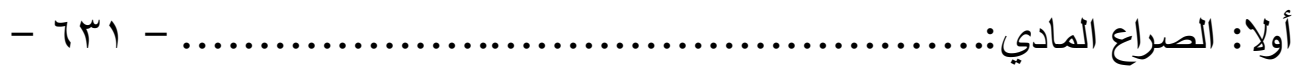

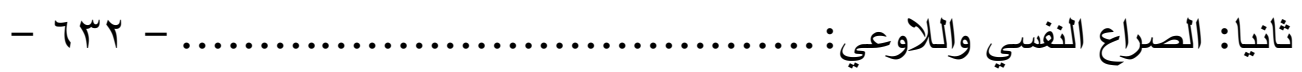

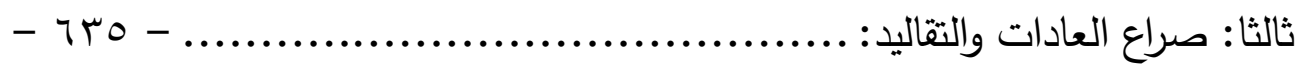

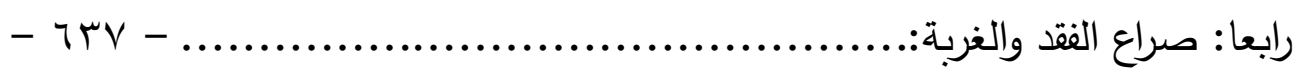

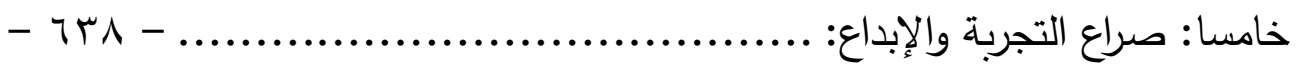

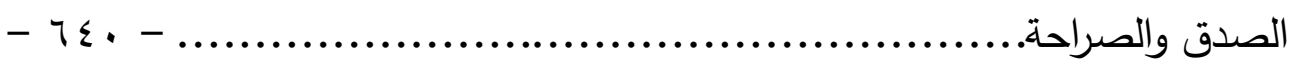

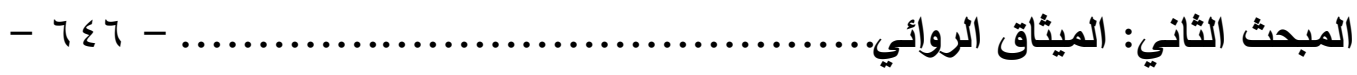

الحقيقة والخيال...................................................................

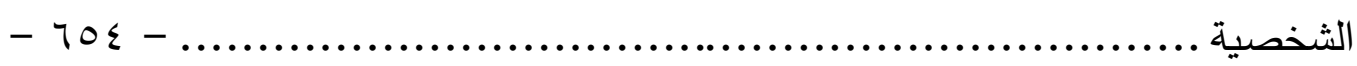

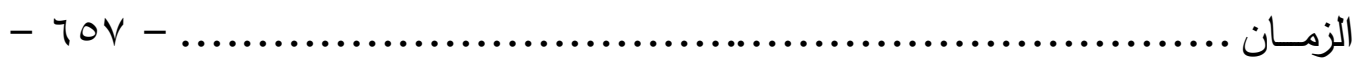

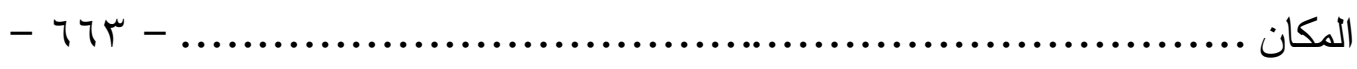

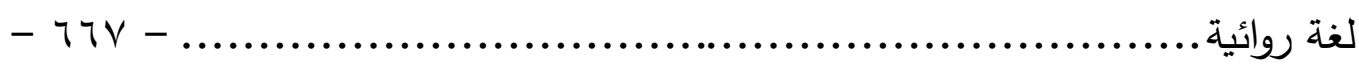

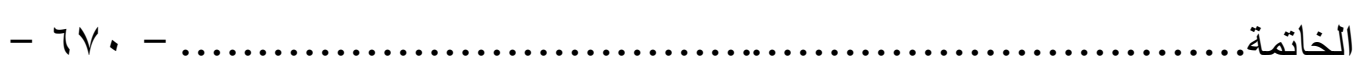

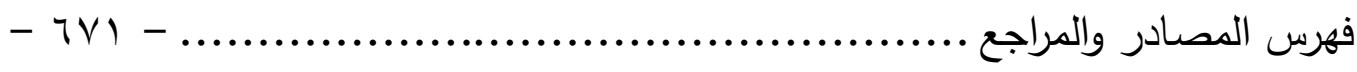

